\title{
Д.
}

\section{Statistische onderbouwing aantal grepen voor het schatten van de onzuiverheid in gesorteerde kunststofproducten}

Eric Boer, Ulphard Thoden van Velzen en Marieke Brouwer

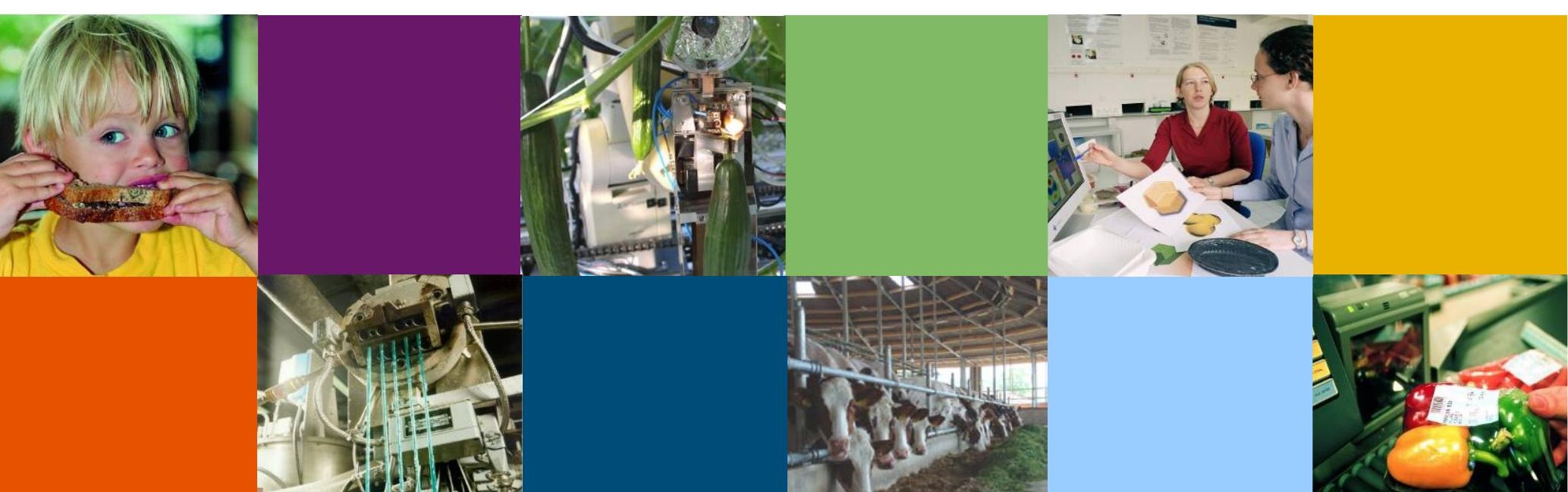




\section{Colofon}

Titel Statistische onderbouwing aantal grepen voor het schatten van de onzuiverheid in gesorteerde kunststofproducten

Auteur(s) Eric Boer, Ulphard van Thoden van Velzen en Marieke Brouwer

Nummer $\quad 1760$

ISBN-nummer 978-94-6257-992-7

Publicatiedatum 20 oktober 2017

Doi-nummer $\quad$ https://doi.org/10.18174/419600

Versie Definitief

Vertrouwelijk Nee

OPD-code $\quad 16620173$

Goedgekeurd door Nicole Koenderink

Review Intern en extern gereviewd

Naam reviewer Nicole Koenderink

Financier Nedvang

Opdrachtgever Nedvang

Wageningen Food \& Biobased Research

P.O. Box 17

NL-6700 AA Wageningen

Tel: +31 (0)317480084

E-mail: info.fbr@wur.nl

Internet: www.wur.nl/foodandbiobased-research

(C) Wageningen Food \& Biobased Research, instituut binnen de rechtspersoon Stichting Wageningen Research Alle rechten voorbehouden. Niets uit deze uitgave mag worden verveelvoudigd, opgeslagen in een geautomatiseerd gegevensbestand of openbaar gemaakt in enige vorm of op enige wijze, hetzij elektronisch, hetzij mechanisch, door fotokopieën, opnamen of enige andere manier, zonder voorafgaande schriftelijke toestemming van de uitgever. De uitgever aanvaardt geen aansprakelijkheid voor eventuele fouten of onvolkomenheden.

All rights reserved. No part of this publication may be reproduced, stored in a retrieval system of any nature, or transmitted, in any form or by any means, electronic, mechanical, photocopying, recording or otherwise, without the prior permission of the publisher. The publisher does not accept any liability for inaccuracies in this report. 


\section{Inhoudsopgave}

1 Inleiding 4

1.1 Verzamelde data 5

1.2 Focus en afbakening 5

2 Methoden $\quad 8$

2.1 Schatten van de variatie tussen grepen 8

2.2 Bepaling foutmarge als functie van het aantal grepen 8

2.3 Veronderstellingen 9

3 Resultaten 10

3.1 Visualisatie van de deelmetingen 10

3.2 Selectie van de "top drie" 11

3.3 Foutmarges als functie van het aantal grepen 11

3.4 Effect van het aantal grepen per meting op het jaargemiddelde 14

3.5 Additioneel onderzoek naar normaliteit van de data 15

$\begin{array}{ll}\text { 3.5.1 Controle van normaliteit } & 15\end{array}$

$\begin{array}{ll}\text { 3.5.2 Resampling van variatie tussen grepen. } & 16\end{array}$

4 Discussie 20

5 Conclusies 22

6 Referenties 23

$\begin{array}{ll}\text { Bijlagen } & 24\end{array}$ 


\section{Inleiding}

Gescheiden ingezamelde kunststofverpakkingen en drankenkartons worden gesorteerd. De sorteerproducten van deze kunststofverpakkingen en drankenkartons worden verhandeld aan recyclingbedrijven. Dit rapport geeft een statistische onderbouwing voor de bepaling van het aantal grepen per meting voor het schatten van onzuiverheid in gesorteerde kunststoffracties en drankenkartons. Het is van groot belang voor de monitoringsorganisatie Nedvang en alle Raamovereenkomstpartijen (Vereniging Nederlandse Gemeenten (VNG), het verpakkende bedrijfsleven en de Rijksoverheid) dat de gesorteerde producten voldoen aan de hiervoor geldende kwaliteitscriteria (DKR specificaties). Het bepalen van de zuiverheid van de gesorteerde kunststofproducten gebeurt aan de hand van steekproeven. Bij een kwaliteitsmeting worden per kunststofproduct $n$ grepen zo representatief mogelijk genomen uit de partij die op het moment van meting bij het sorteerbedrijf beschikbaar is. Ten behoeve van dit onderzoek zijn 4 grepen samengevoegd tot één deelmeting en is van deze deelmeting de zuiverheid gemeten en geregistreerd, deze opzet is weergegeven in Figuur 1. Gedurende een jaar worden er meerdere kwaliteitsmetingen gedaan per sorteerinstallatie. In het onderstaande kader zijn definities gegeven van de belangrijkste veel gebruikte termen in dit onderzoek.
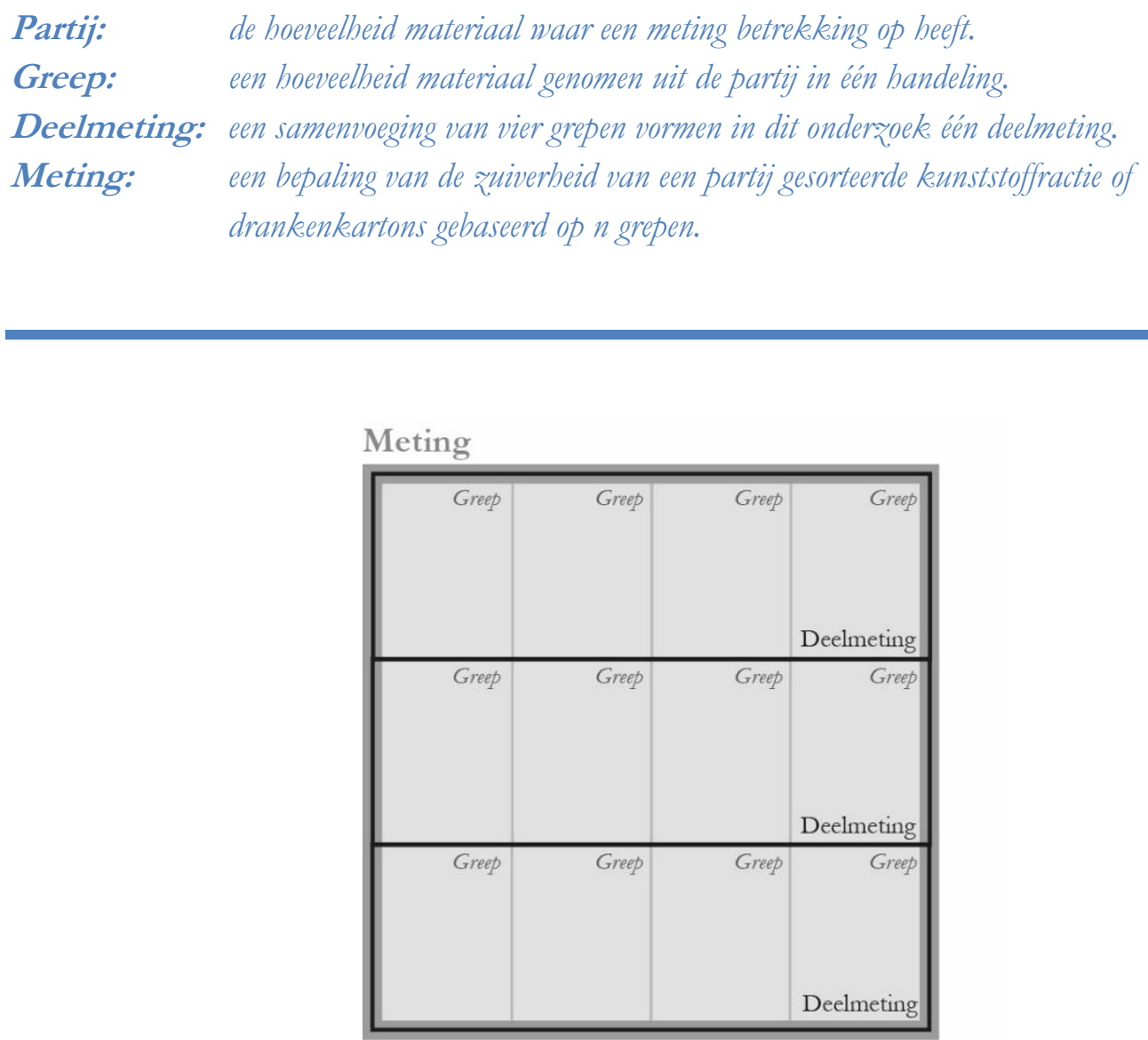

Figuur 1 Overzicht een meting zoals uitgevoerd in dit onderzoek. Een meting is opgebouwd uit 12 grepen, 4 grepen samen vormen één deelmeting. Er zijn dus drie deelmetingen per meting. 
Nedvang en VNG hebben Wageningen UR gevraagd het huidig aantal van 12 grepen per meting te toetsen op nauwkeurigheid van de meetresultaten van deze kwaliteitsmetingen. Met andere woorden hoeveel grepen zijn voldoende om de zuiverheid van de sorteerproducten in de gewenste betrouwbaarheid te meten. Dit is doorgerekend voor 6 sorteerproducten: Mix, Folie, PE, PP, PET en drankenkartons. De verschillende sorteerproducten moeten voldoen aan de bijbehorende DKR specificaties, waarin per specificatie 5 tot 8 afzonderlijke kwaliteitscriteria genoemd staan. De meeste kwaliteitscriteria geven maximale percentages aan, maar er zijn ook enkele kwaliteitscriteria die op de afwezigheid van onzuiverheden zijn gebaseerd. Het eerste soort kwaliteitscriterium werd wel meegenomen, de kwaliteitscriteria die zijn gebaseerd op af/aanwezigheid zijn niet meegenomen in dit rapport.

Wageningen UR zal op basis van meetresultaten de mate van onzekerheid berekenen voor deze kwaliteitscriteria. Vervolgens zal met statistische onderbouwing worden ingeschat hoe hoog deze mate van onzekerheid zal zijn bij een ander aantal grepen. Op basis van het gewenste niveau van betrouwbaarheid kan vervolgens het gewenst aantal grepen worden bepaald.

Wageningen UR heeft dit onderzoek onafhankelijk uitgevoerd. Daarnaast heeft er een inhoudelijk externe review plaatsgevonden door Cyclos $\mathrm{GmbH}$ op de concept versie van dit rapport in april 2017. Het review rapport is opgenomen in de bijlagen (Bijlage C) inclusief onze reactie (Bijlage D).

\subsection{Verzamelde data}

Van augustus tot en met december 2016 zijn er bij 7 sorteerinstallaties op 5 momenten metingen uitgevoerd door sorteerploegen in opdracht van Nedvang. Dit is gebeurd conform het "Meetprotocol samenstelling kunststofverpakkingsafval en drankenkartons afkomstig uit huishoudens" (Nedvang, 2016). Bij de meeste installaties werden alle 6 de sorteerproducten uit kunststofverpakkingen en drankenkartons gemeten. Per meting werden er 12 grepen zo representatief mogelijk genomen uit de partij die er op dat moment lag. Deze grepen werden samengevoegd tot 3 deelmetingen van elk 4 grepen. Per sorteerproduct werden alle benodigde kwaliteitsmetingen verricht voor de DKR specificaties. Wageningen UR heeft zich niet bemoeid met de kwaliteitscontrole. Nedvang gaf de meetresultaten aan Wageningen UR voor de statistische analyse.

\subsection{Focus en afbakening}

Dit project volgt op het onderzoek en het rapport over de "Beoordelingssystematiek voor de verwerking van resultaten van metingen van de fysieke samenstelling” van Cyclos (Cyclos, 2016). In deze paragraaf wordt uitgelegd wat de overeenkomsten en verschillen zijn tussen het onderzoek in dit rapport en het onderzoek beschreven in "Beoordelingssystematiek voor de verwerking van resultaten van metingen van de fysieke samenstelling". 


\section{Overeenkomsten}

Beide onderzoeken gaan over de nauwkeurigheid van het bepalen van de zuiverheid in de gesorteerde producten. Het betreft dezelfde producten en ook dezelfde kwaliteitscriteria. Voor de beoordelingssystematiek en dit onderzoek geldt beide, dat hoe kleiner de variatie is tussen waarnemingen en hoe meer waarnemingen worden gedaan, des te groter de nauwkeurigheid zal zijn.

\section{Verschillen}

Belangrijk verschil tussen dit onderzoek en de beoordelingssystematiek is dat dit onderzoek focust op het aantal grepen per meting. De beoordelingssystematiek richt zich op de gemiddelde onzuiverheid per DKR criterium per gesorteerd product per jaar en berekent daarmee een gemiddelde over metingen. Dus dit rapport zegt iets over de nauwkeurigheid van een kwaliteitsmeting bij één meting op basis van het aantal (n) grepen. De beoordelingssystematiek daarentegen zegt iets over de nauwkeurigheid van het jaargemiddelde op basis van het aantal metingen gebaseerd op $n$ grepen. Het verschil betreft dus de variatie binnen metingen (tussen grepen) en de variatie tussen metingen. In Figuur 2 is dit gevisualiseerd. In Figuur 2 is de variatie tussen metingen groter dan de variatie binnen metingen. Dit zal per sorteerinstallatie en per gesorteerd product verschillen, en dus kunnen er op basis van dit rapport geen conclusies worden getrokken over de variatie tussen metingen.

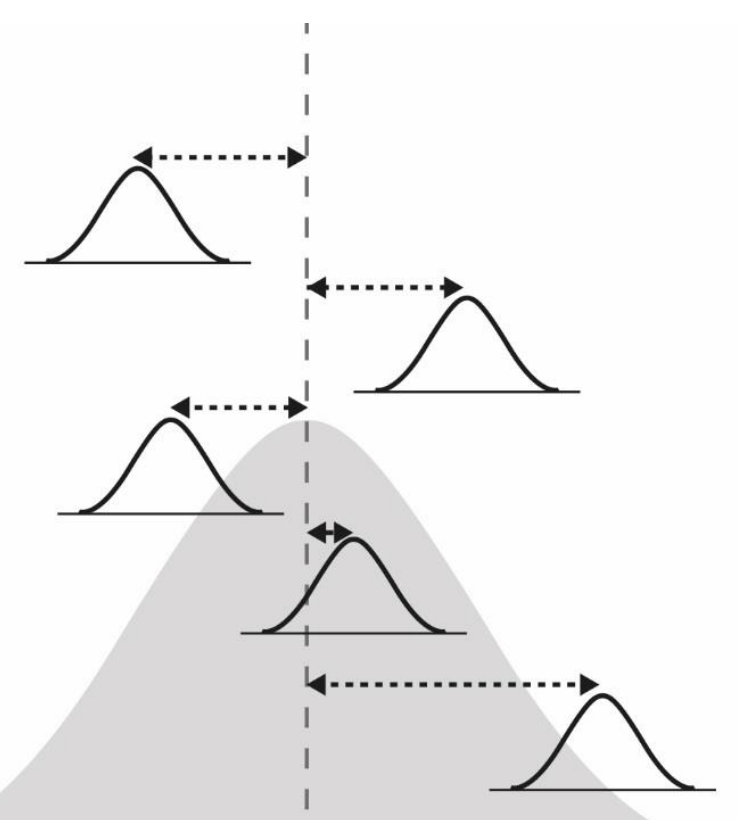

Figuur 2 De stippellijn is het jaargemiddelde. De grijze verdeling stelt de variatie tussen metingen voor. De 5 kleinere verdelingen de variatie binnen metingen tussen grepen.

In de beoordelingssystematiek zal de variatie tussen metingen het belangrijkste zijn, in dit rapport de variatie binnen metingen (en dus tussen grepen). 
Een tweede belangrijk verschil is dat de beoordelingssystematiek een bepaalde rekenwijze introduceert waarmee een correctiefactor wordt uitgerekend. Dit wordt gedaan met alleen een bovengrens van een betrouwbaarheidsinterval. Dit rapport geeft echter de nauwkeurigheid van de kwaliteitsmeting als functie van het aantal grepen met een onder- en bovengrens.

Tenslotte, wordt in dit rapport de variatie tussen grepen geschat op basis van meerdere sorteerinstallaties. Dat kunnen alle sorteerinstallaties zijn, maar ook een selectie van sorteerinstallaties. Terwijl in de beoordelingssystematiek de variatie per sorteerinstallatie tussen metingen wordt bepaald. 


\section{Methoden}

Dit onderzoek betreft een statistische onderbouwing van de relatie tussen het aantal grepen per meting en de verwachte onzekerheid in de resultaten. In dit hoofdstuk worden de gebruikte statistische methoden toegelicht. Ten slotte worden ook de gemaakte veronderstellingen besproken.

\subsection{Schatten van de variatie tussen grepen}

Voor elk kwaliteitscriterium van de DKR specificatie zijn er per sorteerinstallatie per meting 3 deelmetingen beschikbaar. Deze deelmetingen zijn het resultaat van 4 representatief gekozen grepen. De variatie tussen deelmetingen wordt dus gedempt doordat de deelmetingen een gemiddelde zijn van 4 grepen.

Met behulp van het statistische programma $\mathrm{R}$ (versie 3.2.3) wordt met een mixed model de variatie tussen deelmetingen gekwantificeerd. De sorteerinstallatie is daarbij het zogenoemde fixed effect, en de meetdagen binnen sorteerinstallatie is het random effect. De residuele standaardafwijking tussen deelmetingen die dan nog overblijft, is de standaardafwijking tussen deelmetingen binnen de meetdagen. Daarin zit alle mogelijke variatie die niet te verklaren is door de verschillen tussen sorteerinstallaties en verschillen tussen meetdagen.

De standaardafwijking tussen de deelmetingen is gebaseerd op het gemiddelde van 4 grepen (ook wel standaardfout van een gemiddelde genoemd), daarom geldt:

$$
\text { standaardafwijking tussen deelmetingen }=\frac{\text { standaardafwijking tussen grepen }}{\sqrt{4}}
$$

De standaardafwijking tussen grepen kan dus berekend worden door de berekende standaardafwijking tussen deelmetingen te vermenigvuldigen met een factor twee.

\subsection{Bepaling foutmarge als functie van het aantal grepen}

Op basis van de geschatte standaardafwijking tussen grepen per criterium per sorteerproduct kunnen foutmarges berekend worden. Deze foutmarges geven weer hoeveel de gemeten waarde van een bepaald criterium gebaseerd op $n$ grepen kan afwijken. Deze foutmarges zijn in dit rapport gebaseerd op de "empirical rule". Deze vuistregel zegt dat 95\% van alle mogelijke waarden in het interval zullen liggen tussen het gemiddelde min twee maal de standaardfout tot het gemiddelde plus twee maal de standaardfout. De foutmarge gebaseerd op $n$ grepen is dan gelijk aan:

$$
\text { Foutmarge }=\mathbf{2 . 0} * \frac{\text { standaardafwijking tussen de grepen }}{\sqrt{n}}
$$

In dit rapport wordt het aantal grepen $n$ per meting gevarieerd tussen de 1 en de 24 . 


\section{Voorbeeld foutmarge}

Stel dat bij een meting van het kunststofproduct Mix een gemiddelde onzuiverheid wordt gevonden van $8 \%$ en dat de foutmarge gelijk is aan 3(\%). Dan betekent dit dat de werkelijke onzuiverheid van de partij Mix bij die sorteerinstallatie geschat wordt op 8\%, maar dat door onnauwkeurigheid het ook een waarde tussen de 5\% en 11\% kan zijn. Deze range wordt berekend op basis van 95\% betrouwbaarheid. Wanneer deze analyse heel vaak wordt herhaald, zal 5\% van de uitkomsten niet de werkelijke onzuiverheid van de partij weergeven.

\subsection{Veronderstellingen}

Bij bijna iedere statistische berekening worden veronderstellingen gemaakt. Hieronder staan puntsgewijs de gemaakte veronderstellingen in bovenstaande berekeningen.

- De grepen zijn aselect gekozen en daarmee representatief voor de partij die op het moment van meting aanwezig is bij een sorteerinstallatie. Dit is belangrijk omdat anders de onzuiverheid van gesorteerde producten systematisch te groot of te klein kan worden ingeschat. Dit is geborgd in het meetprotocol wat gehanteerd wordt door de bedrijven (o.a. Cyclos) die de metingen eind 2016 hebben uitgevoerd.

- Er wordt aangenomen dat het monster (totaal aantal kilogram van de grepen genomen van het gesorteerd product) klein is ten opzichte van de partij die dan op dat moment van een bepaald sorteerproduct aanwezig is. Het monster betreft dus een steekproef uit de aanwezige partij en niet de gehele partij.

- Verondersteld wordt dat de data normaal verdeeld is. Dit is van belang bij het schatten van de variatie tussen grepen en ook dat de foutmarges symmetrisch zijn. In paragraaf 3.5 wordt deze veronderstelling nader geanalyseerd.

- In dit rapport wordt het aantal grepen voor een meting gelijk verondersteld voor alle sorteerinstallaties. Er wordt vanuit gegaan dat een vast aantal grepen per meting moet worden vastgesteld die wordt toegepast bij alle sorteerinstallaties. De berekende standaardafwijking tussen grepen is een gepoolde (samengestelde) schatting van de variatie tussen de grepen. Dit kan als een soort gemiddelde maat voor de variatie tussen grepen beschouwd worden. In de praktijk zal de variatie tussen grepen per sorteerinstallatie verschillen. In paragraaf 3.2 wordt nog nader aandacht besteed aan deze veronderstelling. 


\section{Resultaten}

Voor elk van de 6 sorteerproducten zijn berekeningen gemaakt van de nauwkeurigheid van de bepaling van de onzuiverheid in gesorteerde kunststofproducten voor de kwantitatief geformuleerde kwaliteitscriteria in de DKR specificaties. Dit resulteert in grafieken en tabellen voor de foutmarges als functie van het aantal grepen (paragraaf 3.3). Voorafgaand aan deze analyses is per sorteerproduct en per criterium een visualisatie gemaakt van de deelmetingen. Deze visualisaties laten duidelijk zien dat de variatie tussen deelmetingen bij sommige sorteerinstallaties groter is. Daarom wordt de variatie tussen grepen ook aanvullend geschat aan de hand van de 3 sorteerinstallaties met kleinste variatie tussen deelmetingen binnen de metingen (paragraaf 3.2). In dit hoofdstuk wordt het kunststofproduct Mix besproken. De resultaten van de andere sorteerproducten staan in de bijlagen.

\subsection{Visualisatie van de deelmetingen}

In Figuur 3 staat de onzuiverheid van deelmetingen in het kunststofproduct Mix voor 6 sorteerinstallaties en voor de 5 metingen per installatie. De boxplots geven de totale verdeling van de waarnemingen van onzuiverheid per installatie weer. Met de symbolen in verschillende kleuren worden de 3 deelmetingen per meting gevisualiseerd.

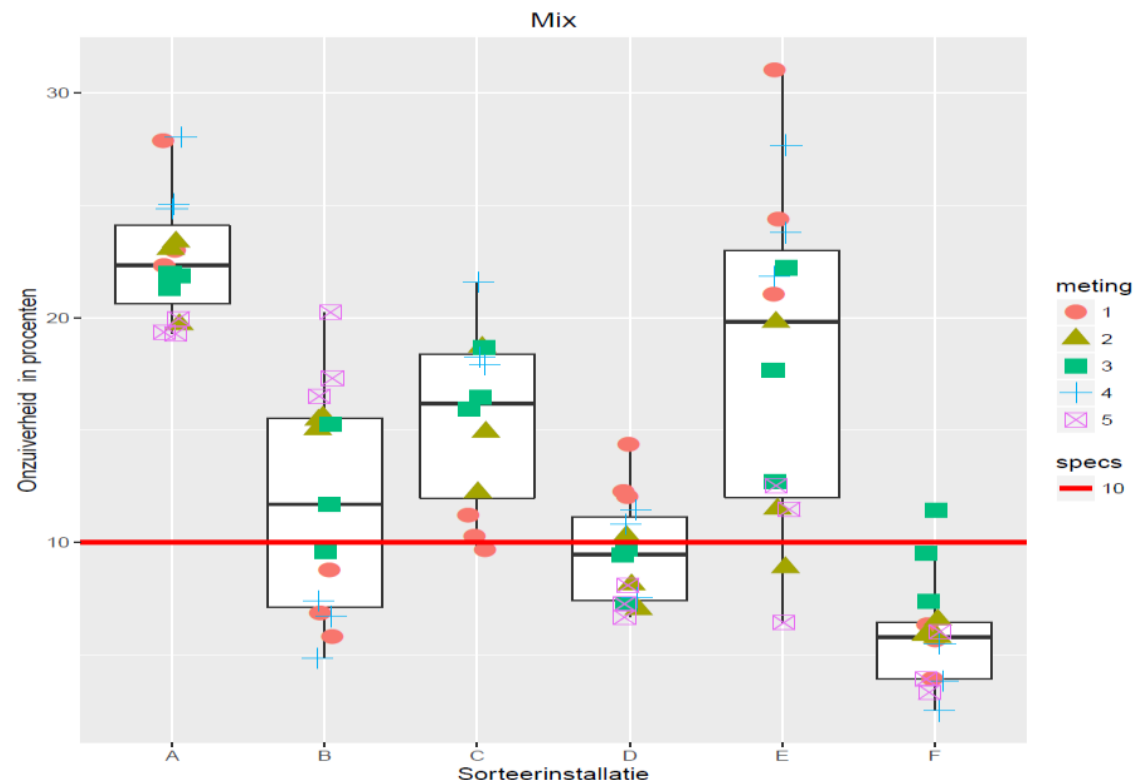

Figuur 3 Onzuiverheid in Mix voor 6 sorteerinstallaties $(\mathrm{A} \mathrm{t} / \mathrm{m} \mathrm{F}$ ), 5 metingen per installatie (punten in verschillende kleuren en symbolen). Elk punt is een deelmeting van onzuiverheid gebaseerd op 4 grepen. De rode lijn geeft de DKR specificatie aan voor de maximale onzuiverheid in Mix.

Figuur 3 laat zien dat er aanzienlijke verschillen zijn in onzuiverheid in Mix tussen de verschillende sorteerinstallaties. Daarnaast zijn er behoorlijke verschillen tussen metingen. Bijvoorbeeld bij installatie B, waar metingen 1 en 4 onder de DKR specificatie vallen, maar de andere metingen vallen er (gemiddeld) boven. De bepaalde variatie tussen deelmetingen, is de (samengestelde) variatie tussen de zelfde symbolen binnen sorteerinstallaties. Sorteerinstallaties E 
zal een aanzienlijke bijdrage leveren aan de hoogte van de variatie tussen deelmetingen en daarmee de standaardafwijking tussen grepen verhogen.

\subsection{Selectie van de "top drie"}

Uit de figuren en uit de analyses blijkt dat sommige sorteerinstallaties (verschillend per criterium en per sorteerproduct) grote invloed hebben op de berekende variatie tussen grepen. De berekende standaardafwijking tussen grepen is een samengestelde (gepoolde) schatting, onder de veronderstelling dat deze standaardafwijking tussen grepen gelijk is voor alle sorteerinstallaties (zie paragraaf 2.3). Voor de nauwkeurigheid van de schatting van de standaardafwijking tussen grepen blijft een samengestelde schatting van deze variatie nog steeds wenselijk. Echter, in Figuur 3 is duidelijk te zien dat sorteerinstallatie $\mathrm{E}$ een veel grotere spreiding heeft dan de andere sorteerinstallaties. Dit betreft zowel de variatie tussen metingen als tussen grepen binnen metingen. Kennelijk heeft sorteerinstallatie E de procesvoering minder goed op orde dan de andere sorteerinstallaties. Dit domineert de schatting van de variatie tussen grepen teveel en daarom is de variatie tussen grepen geschat voor de drie sorteerinstallaties met de kleinste variatie tussen de deelmetingen. Dit is uitgevoerd per sorteerproduct apart en voor alle stromen voor het criterium onzuiverheid. Voor deze analyse wordt per sorteerinstallatie de variatie tussen metingen en binnen metingen (deelmetingen gebaseerd op 4 grepen) bepaald voor het criterium onzuiverheid. De 3 sorteerinstallaties met de kleinste variatie tussen deelmetingen worden geselecteerd. Vervolgens worden voor deze 3 sorteerinstallaties gezamenlijk opnieuw de standaardafwijking tussen grepen bepaald voor alle DKR specificaties.

\subsection{Foutmarges als functie van het aantal grepen}

Per sorteerproduct is de foutmarge berekend, zoals gedefinieerd in paragraaf 2.2. In Figuur 4 is deze foutmarge gevisualiseerd voor het kunststofproduct Mix voor 6 van de DKR criteria die horen bij het kunststofproduct Mix. Figuur 4 is gebaseerd op alle 6 de sorteerinstallaties. 


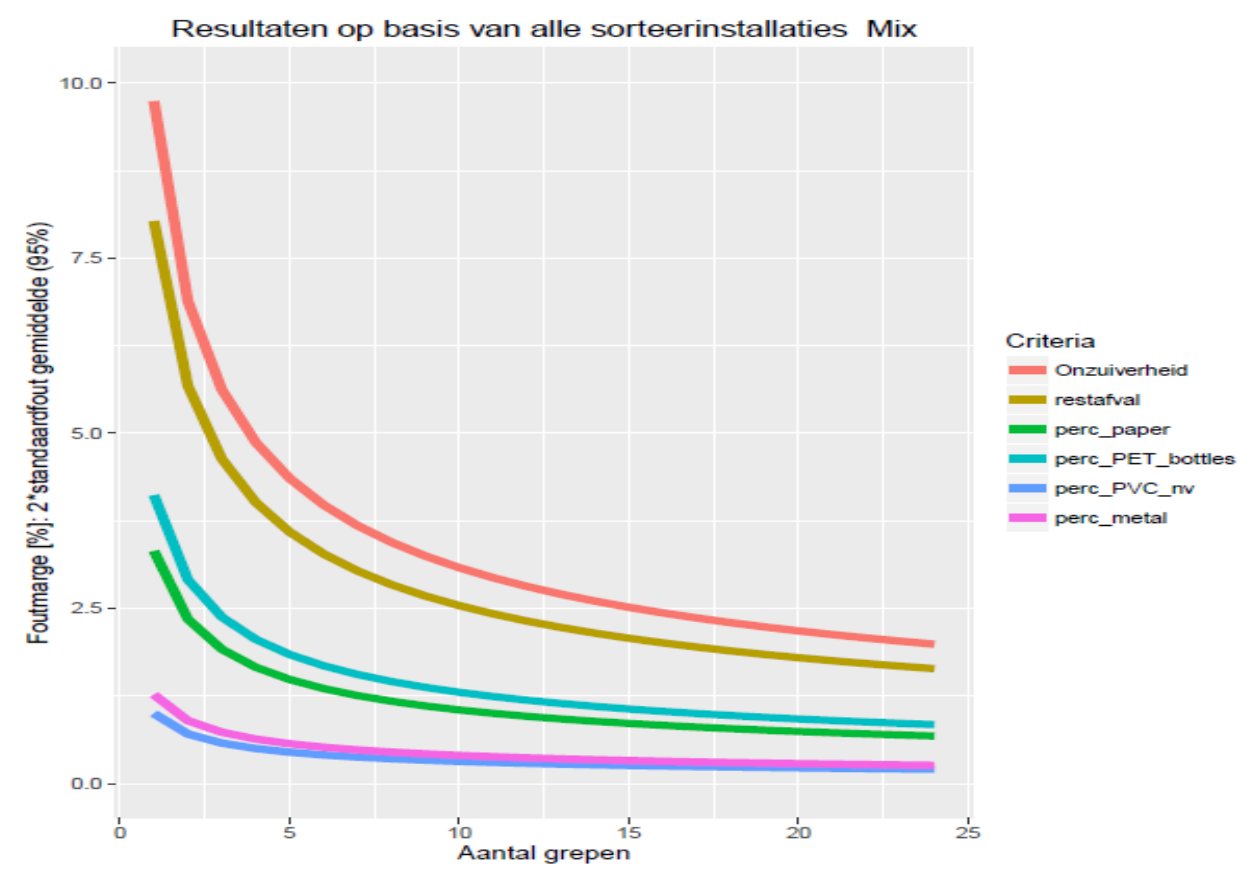

Figuur 4 Foutmarge (95\% betrouwbaarheid) van de 6 DKR criteria als functie van het aantal grepen (1-24).

Figuur 4 laat een typische curve zien voor het berekenen van de nauwkeurigheid gebaseerd op $n$ waarnemingen, in dit geval het aantal grepen per meting. De nauwkeurigheid van de meting wordt snel beter als het aantal grepen wordt verhoogd. Naar verloop van het aantal grepen wordt de extra toegevoegde waarde van een opnieuw aselect gekozen greep minder. De foutmarge daalt minder hard van 12 naar 13 grepen dan van 2 naar 3 grepen. Er zijn aanzienlijke verschillen in foutmarges tussen de verschillende criteria. Daarbij is het goed op te merken dat de DKR specificatie van de verschillende criteria aanzienlijk verschillen in toegestane maximale percentages aan onzuiverheid.

Zoals in sectie 3.2 aangegeven, kan de foutmarge sterk beïnvloed worden door sorteerinstallaties die een grote variatie hebben tussen de deelmetingen. In Figuur 5 is dezelfde grafiek getekend als in Figuur 4, maar dan gebaseerd op de 3 sorteerinstallaties met de laagste variatie tussen deelmetingen voor het criterium onzuiverheid. 


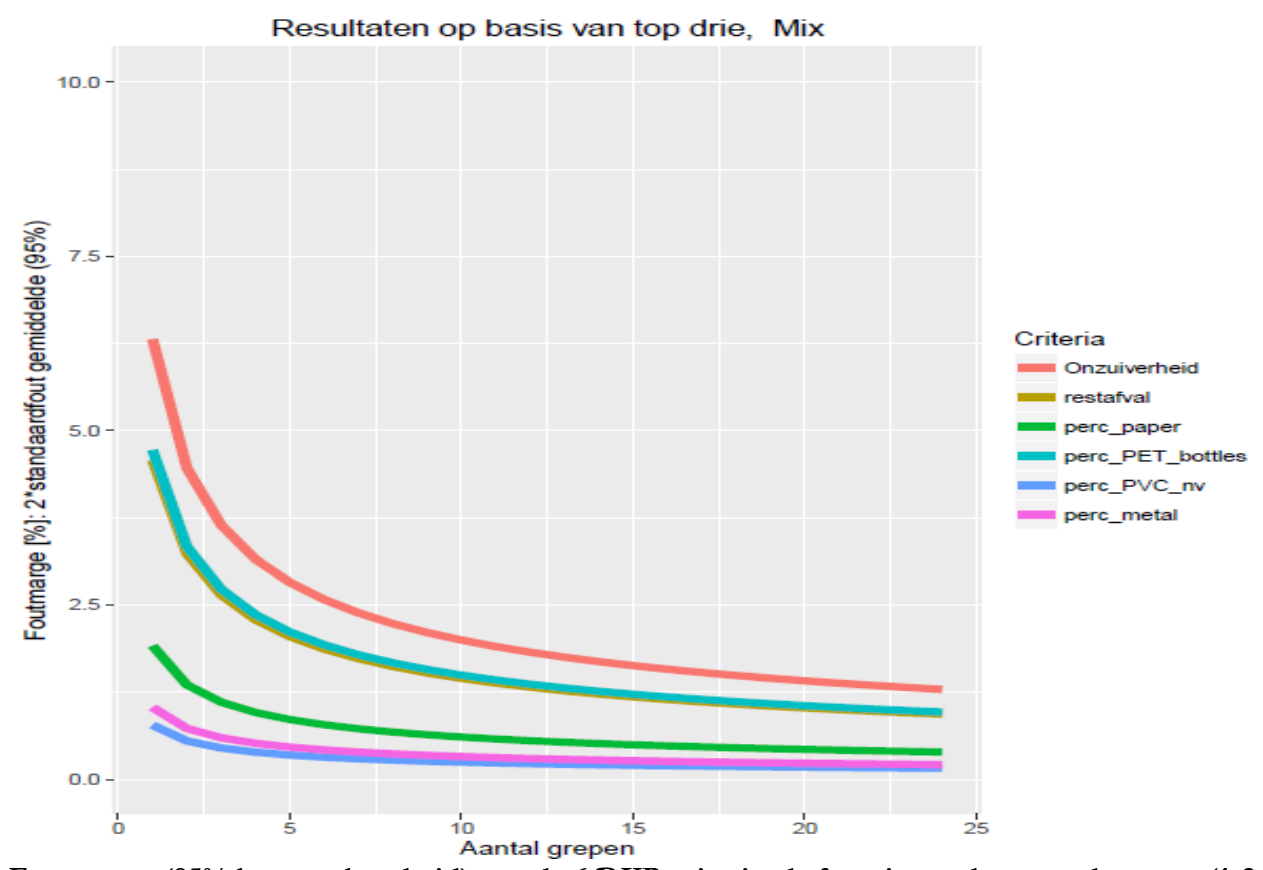

Figuur 5 Foutmarge (95\% betrouwbaarheid) van de 6 DKR criteria als functie van het aantal grepen (1-24). Nu is de variatie tussen grepen gebaseerd op de "top drie" van de 6 sorteerinstallaties.

De berekende foutmarges in Figuur 5 zijn, zoals kon worden verwacht, aanzienlijk lager dan in Figuur 4.

In Tabel 1 wordt voor een beperkt aantal grepen $(n=8,12$, en 16) voor de 6 criteria en voor beide berekeningen (foutmarges gebaseerd op alle sorteerinstallaties en op de top drie) de foutmarge gegeven. Op de onderste regel staan de DKR specificaties, de maximale waarde waaraan de het betreffende materiaal moet voldoen. De onderste regel geeft de mogelijkheid om de foutmarge relatief te bezien ten opzichte van de DKR criteria. De foutmarge voor restafval $($ criterium $=3)$ is relatief veel groter dan de foutmarge voor onzuiverheid (criterium $=10)$.

Tabel 1 Foutmarges voor het kunststofproduct Mix voor een beperkt aantal grepen en vergeleken met de absolute waarde van de grenswaarde van het criterium in de DKR specificatie.

\begin{tabular}{|c|c|c|c|c|c|c|c|}
\hline \multirow[t]{2}{*}{ Mix } & \multirow{2}{*}{$\begin{array}{c}\text { Grepen, } \\
{[\#]}\end{array}$} & \multicolumn{6}{|c|}{ Foutmarges in de onderstaande criteria } \\
\hline & & $\begin{array}{c}\text { Onzuiverheid, } \\
{[\%]}\end{array}$ & $\begin{array}{c}\text { Restafval, } \\
{[\%]}\end{array}$ & Papier, $[\%]$ & $\begin{array}{c}\text { PET flessen, } \\
{[\%]}\end{array}$ & PVC, $[\%]$ & Metaal, $[\%]$ \\
\hline \multirow{3}{*}{$\begin{array}{l}\text { Alle } \\
\text { sorteerinstallaties }\end{array}$} & 8 & 3.44 & 2.84 & 1.17 & 1.46 & 0.35 & 0.45 \\
\hline & 12 & 2.81 & 2.32 & 0.96 & 1.19 & 0.29 & 0.37 \\
\hline & 16 & 2.44 & 2.01 & 0.83 & 1.03 & 0.25 & 0.32 \\
\hline \multirow{3}{*}{$\begin{array}{l}\text { Top } 3 \\
\text { sorteerinstallaties }\end{array}$} & 8 & 2.23 & 1.62 & 0.68 & 1.67 & 0.27 & 0.36 \\
\hline & 12 & 1.82 & 1.32 & 0.55 & 1.36 & 0.22 & 0.30 \\
\hline & 16 & 1.58 & 1.14 & 0.48 & 1.18 & 0.19 & 0.26 \\
\hline DKR criterium & & 10 & 3 & 5 & 4 & 0.5 & 2 \\
\hline
\end{tabular}




\subsection{Effect van het aantal grepen per meting op het jaargemiddelde}

Met het aantal grepen per meting wordt de nauwkeurigheid per meting bepaald. Hoe meer grepen hoe kleiner de foutmarges (zie tabel 1). In deze paragraaf wordt nagegaan hoe het aantal grepen doorwerkt op de foutmarge van het jaargemiddelde. Het aantal metingen per jaar wordt vastgesteld op 12. Met behulp de beschreven methode in paragraaf 2.1 worden variantiecomponenten bepaald. Dit betreft de variantie tussen metingen en de variantie tussen grepen, bepaald op de top drie.

In Figuur 6 staat de visualisatie van het effect het aantal grepen per meting voor het kunststofproduct Mix.

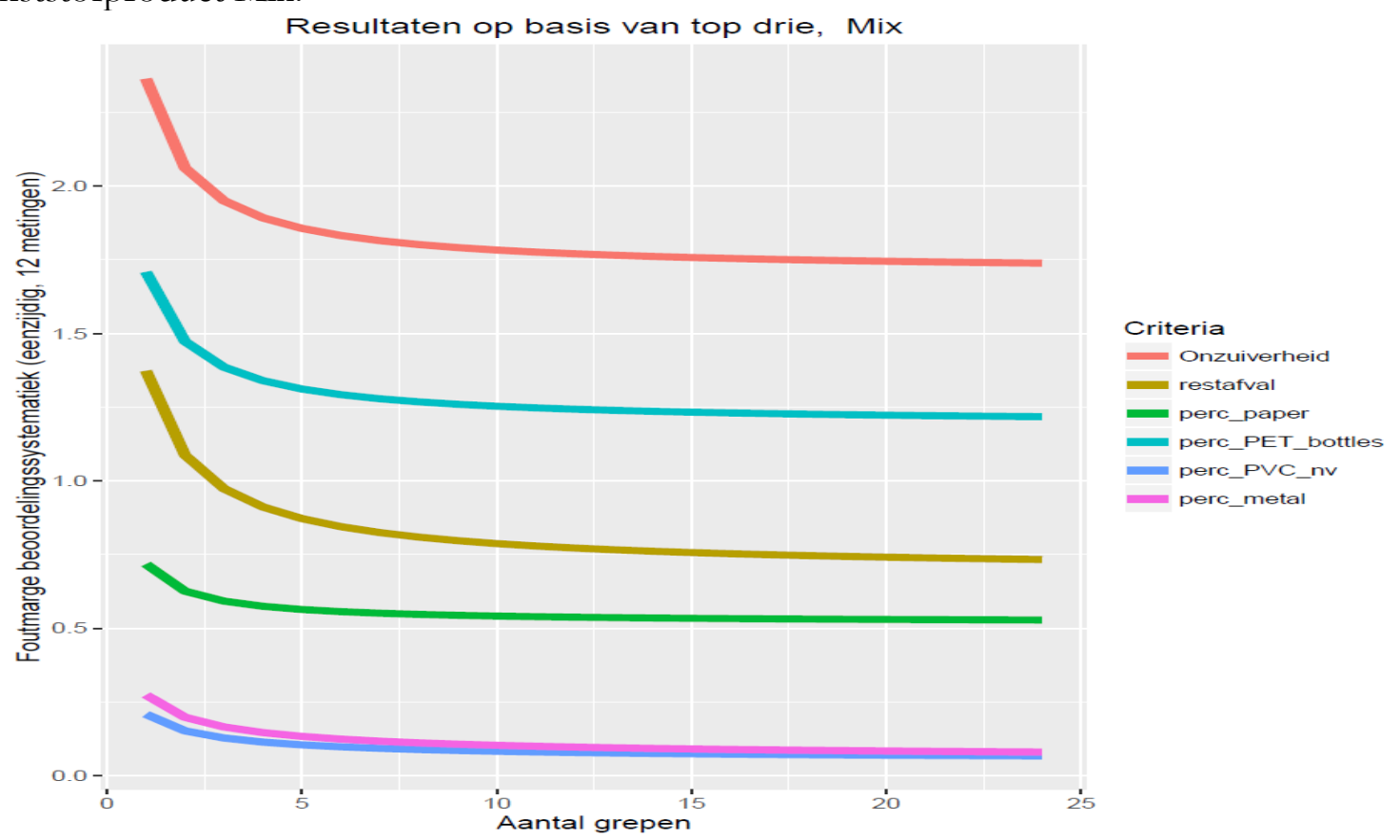

Figuur 6 Foutmarge van het jaargemiddelde ( $95 \%$ betrouwbaarheid, eenzijdig) gebaseerd op de beoordelingssystematiek van de 6 DKR criteria voor het kunststofproduct mix als functie van het aantal grepen (1-24) per meting. Hierbij uitgaande van een vast aantal metingen van 12 per jaar.

Het effect van het aantal grepen per meting is nu niet helemaal gelijk voor alle 6 de DKR criteria voor Mix. Dit komt omdat per criterium de variantie tussen metingen en tussen grepen berekend wordt. Soms kan de variatie vooral bestaan uit de variatie tussen grepen, dat betekent dat de (on)zuiverheid tussen metingen vrij constant zijn. Het kan ook zijn dat de variatie tussen metingen juist groot is. Dan zal de zuiverheid van gesorteerde kunststofstroom gedurende het jaar (sterk) kan variëren. De formule waarmee de foutmarge van het jaargemiddelde wordt berekend:

$$
\text { Foutmarge }=t(0.95,11) * \sqrt{\frac{\sigma_{m}^{2}}{12}+\frac{\sigma_{g}^{2}}{12 * n}}=1.796 * \sqrt{\frac{\sigma_{m}^{2}}{12}+\frac{\sigma_{g}^{2}}{12 * n}}
$$

Waarbij $\sigma_{m}^{2}$ gelijk is aan de variantie tussen metingen en $\sigma_{g}^{2}$ gelijk is aan de variantie tussen grepen. Het aantal grepen per meting is gelijk aan $n$. 
Deze foutmarge is gebaseerd op de berekening die wordt gehanteerd in de beoordelingssystematiek. Het betreft een foutmarge waarmee de (eenzijdige) bovengrens wordt berekend. Het aantal grepen per meting heeft een beperkte invloed op de nauwkeurigheid van het jaargemiddelde bij 12 metingen per jaar. In figuur 6 is te zien vanaf welk aantal grepen de lijn afvlakt en er dus een beperkte winst wordt behaald op de nauwkeurigheid van het jaargemiddelde door meer grepen te nemen.

\subsection{Additioneel onderzoek naar normaliteit van de data}

In de berekeningen hierboven is verondersteld dat de data normaal verdeeld zijn voor het bepalen van aantal grepen per meting. In deze paragraaf wordt nagegaan of deze veronderstelling redelijk is. Er wordt dus niet gekeken naar de normaliteit tussen metingen (voor bepaling van een jaargemiddelde).

\subsubsection{Controle van normaliteit}

Vaak wordt op basis van Q-Q-plots beoordeeld of data normaal verdeeld is en of er afwijkingen zijn ten opzicht van de normale verdeling. Er is ook een statistische toets voor, de zogenaamde Kolmogorov-Smirnov toets. Deze toets geeft aan of de data significant afwijken van de normale verdeling. Dit is toegepast op de deelmetingen binnen metingen van de top drie van sorteerinstallaties, totaal zo'n 45 deelmetingen per criterium binnen een gesorteerd product. In Tabel 2 staan de P-waarden voor de Kolmogorov-Smirnov toets voor de deelmetingen van de verschillende fracties voor alle sorteerproducten.

Tabel 2 Toetsing van normaliteit op basis van deelmetingen per fractie per gesorteerd product. Waarden in de tabel zijn de P-waarde van de toets. Wanneer de P-waarde onder de 0.05 is dat aangegeven met de rode arcering.

\begin{tabular}{|c|c|c|c|c|c|c|}
\hline & Mix & DK & PET & PE & PP \\
\hline totale onzuiverheid & 0.460 & 0.708 & 0.007 & 0.753 & 0.550 \\
\hline restafval & 0.828 & 0.001 & 0.000 & 0.004 & 0.036 \\
\hline perc_paper & 0.000 & 0.041 & 0.747 & & \\
\hline perc_PET_bottles & 0.247 & & & \\
\hline perc_PVC_nv & 0.000 & & & \\
\hline perc_metal & 0.000 & 0.000 & 0.000 & 0.000 \\
\hline perc_kunststof & & 0.007 & & & \\
\hline perc_other_plastic & & & 0.003 & \\
\hline perc_PET_other & & & 0.219 & & \\
\hline perc_Folies & & & & 0.000 \\
\hline perc_Vormvast_PP/PE & & & & 0.044 \\
\hline perc_Geexpandeerd_kunststof & & & & 0.001 \\
\hline
\end{tabular}

Voor het criterium totale onzuiverheid is het in het algemeen de aanname van normaal verdeelde data juist. Echter, voor de andere criteria wordt vaak of altijd (percentage metaal) significante afwijkingen genoteerd van de normale verdeling.

Uit de boxplots van dit onderzoek (zie bijlagen) en uit ervaring van eerdere onderzoeken is bekend dat de onzuiverheid van gesorteerde kunststofstromen vaak de neiging heeft scheef naar rechts te zijn verdeeld. Dat betekent dat vaak de onzuiverheid op een relatief laag niveau 
schommelt, met af en toe een greep met een hoge onzuiverheid. De data worden begrensd door nul procent onzuiverheid voor het minimum van de fractie. Waar de maximale fractie in onzuiverheid wordt bepaald door de procesvoering van de sorteerinstallaties. De absolute bovengrens van $100 \%$ onzuivere fractie zal hopelijk nooit gehaald worden. Niet normaliteit is dus vrij gangbaar in gesorteerde kunststofproducten, het effect hiervan op de foutmarge wordt nu met resampling bestudeerd.

\subsubsection{Resampling van variatie tussen grepen.}

Een deel van de beschikbare dataset bevat ook alle onzuiverheden per greep. Van zo'n 9 metingen per gesorteerd product over de verschillende sorteerinstallaties zijn de fractie onzuiverheden van 12 grepen beschikbaar. Deze worden in deze paragraaf gebruikt voor een nader onderzoek naar de consequenties van de niet normaal verdeelde data.

$\mathrm{Nu}$ wordt geen gebruik gemaakt van het berekenen van de standaardafwijking en de normale verdeling om de foutmarge te berekenen, maar nu wordt resampling van de data toegepast. Het idee van deze resampling is om op basis van alle metingen afwijkingen tussen grepen te bepalen. Voor de meeste gesorteerde producten zijn dit 9x12 =108 afwijkingen. Uit deze afwijkingen tussen grepen wordt nu aselect $n$ grepen genomen met teruglegging. Het gemiddelde van de afwijkingen van $n$ grepen wordt vervolgens bepaald. Dit proces wordt 10.000 keer herhaald, zodat er een verdeling komt van foutmarges. Daarvan wordt het 0.025 -punt van de verdeling als ondergrens genomen en de 0.975 -punt als bovengrens. Dit wordt vervolgens weer herhaald voor $n=1$ tot en met $n=24$ grepen. Het resultaat voor Mix voor het percentage papier staat in figuur 7. Figuur 8 laat hetzelfde zien, maar dan voor het criterium percentage PVC niet verpakking. Dit zijn simulaties, dus wanneer de resampling opnieuw gedraaid wordt kunnen daar (geringe) afwijkingen te zien zijn.

Figuur 7 laat zien dat de foutmarges vrij symmetrisch zijn. Dit ondanks het feit dat de deelmetingen van papier niet normaal verdeeld zijn. De foutmarges worden meer symmetrisch naar mate het aantal grepen per meting hoger wordt. Figuur 8 laat zien dat voor het criterium PVC niet verpakking in mix, de foutmarges niet symmetrisch zijn. De foutmarge voor het bepalen van de bovengrens is hoger dan de foutmarge voor de ondergrens. Dit is typisch het geval voor data die scheef naar rechts zijn verdeeld. 


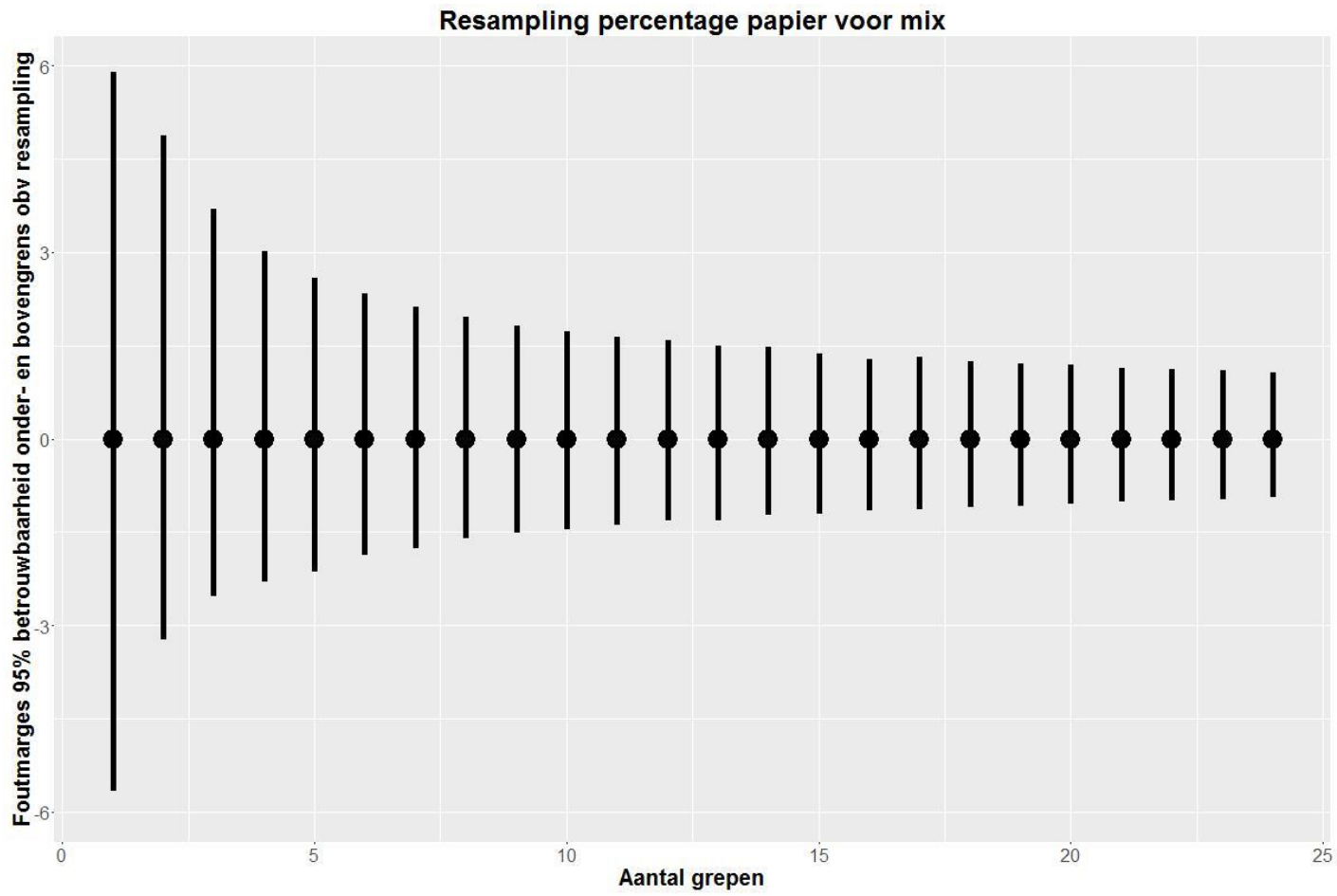

Figuur 7 Foutmarges, onder- en bovengrens voor de gesorteerde kunststofstroom mix voor het percentage papier. Gebaseerd op resampling uit een gedeelte van de dataset waar de kwaliteitsmeting van alle grepen afzonderlijk zijn bepaald.

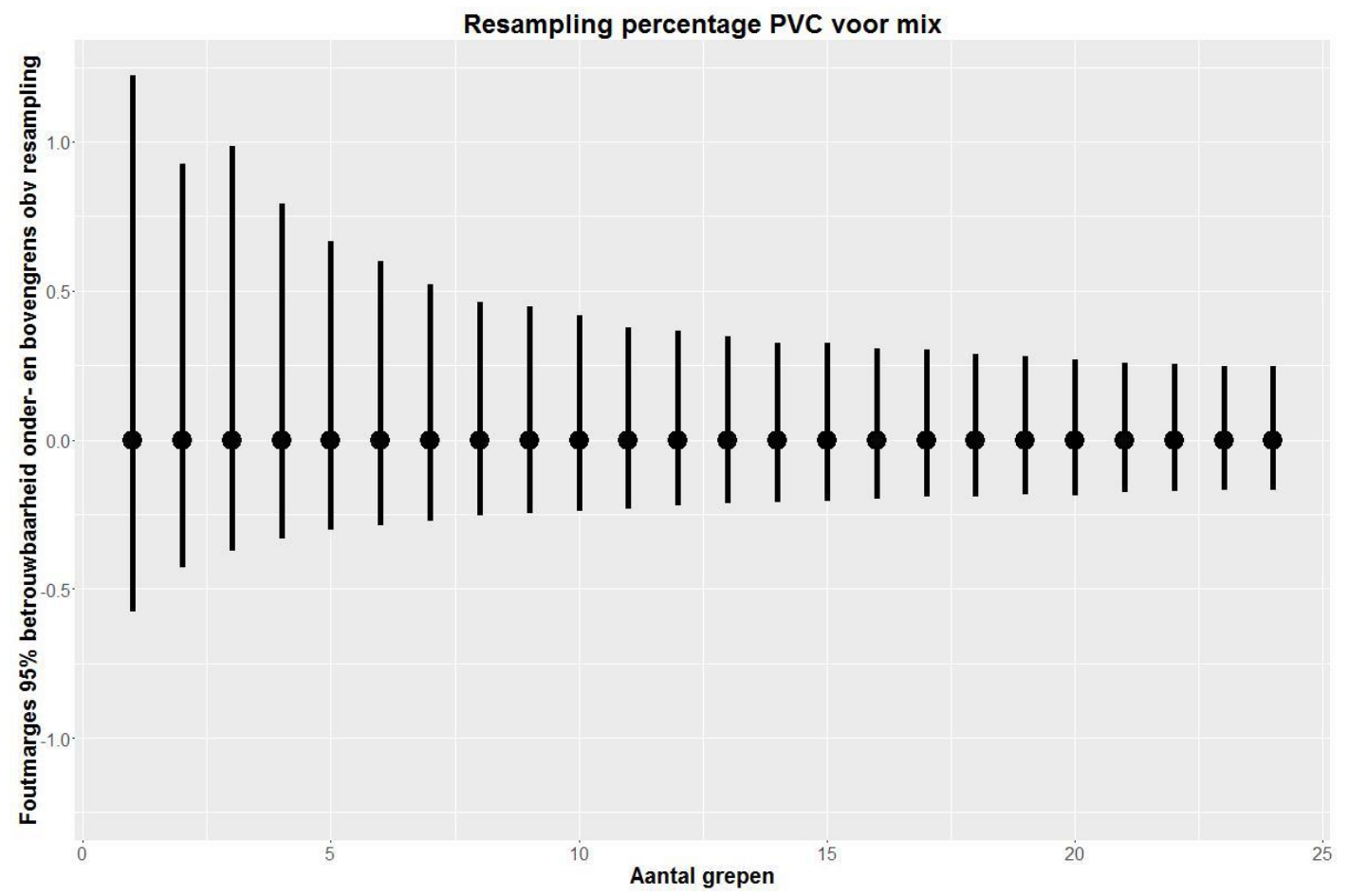

Figuur 8 Foutmarges, onder- en bovengrens voor de gesorteerde kunststofstroom mix voor het percentage PVC niet verpakking. Gebaseerd op resampling uit een gedeelte van de dataset waar de kwaliteitsmeting van alle grepen afzonderlijk zijn bepaald. 
Om inzicht te geven hoeveel de onder- en bovengrens van elkaar verschillen in de resampling is voor elk gesorteerd product en voor elk criterium binnen een product de verhouding tussen onder- en bovengrens bepaald. Daarbij is de bovengrens gedeeld door de ondergrens. Een verhouding 1 betekent dan, dat de onder- en bovengrens even lang zijn. Een getal groter dan1 betekent dat de foutmarge voor de bovengrens groter is dan voor de ondergrens. Des te groter dit getal, des te meer de verdeling scheef naar rechts is. In Tabel 3 zijn deze verhoudingen weergegeven, voor de foutmarge bepaald op 12 grepen per meting.

Tabel 3 De lengte van de foutmarge voor het berekenen van de bovengrens gedeeld door de lengte van de foutmarge voor de ondergrens voor de verschillende gesorteerde producten en de DKR specificaties. Gebaseerd op 12 grepen per meting.

\begin{tabular}{|c|c|c|c|c|c|c|}
\hline & Mix & DK & PET & PE & PP & Folie \\
\hline Onzuiverheid & 1.00 & 1.11 & 0.99 & 1.41 & 1.03 & 1.18 \\
\hline restafval & 0.99 & 1.14 & 1.43 & 1.17 & 1.14 & 1.17 \\
\hline perc_paper & 1.22 & 1.01 & & & & \\
\hline perc_PET_bottles & 1.04 & & & & & \\
\hline perc_PVC_nv & 1.68 & & 2.02 & & & \\
\hline perc_metal & 1.14 & 1.09 & 1.24 & 1.81 & 1.41 & 1.18 \\
\hline perc_kunststof & & 1.36 & 1.09 & & & 1.20 \\
\hline \multicolumn{7}{|l|}{ perc_other_plastic } \\
\hline perc_PET_other & & & 1.04 & & & \\
\hline perc_Folies & & & & 1.27 & 1.22 & \\
\hline perc_Vormvast_PP/PE & & & & 2.31 & 0.98 & \\
\hline erc_Geexpandeerd_kunsts & & & & 1.61 & 1.10 & \\
\hline
\end{tabular}

De verhoudingen in tabel 3 zijn indicatief, omdat ze zijn gebaseerd op een simulatie. Echter de verhoudingen zullen niet geheel anders uitpakken, bij een nieuwe simulatie. Opvallend is dat de verhoudingen bijna altijd groter dan 1. Dat betekent dat de foutmarge voor het bepalen van de bovengrens groter is dan de foutmarge van de ondergrens. Wanneer de symmetrie wordt gebruikt van de normale verdeling, zoals in dit rapport, zal de foutmarge van de ondergrens worden overschat en de foutmarge van de bovengrens worden onderschat. Opvallend is dat bij PE de verhoudingen voor bijna alle criteria behoorlijk hoog zijn. Dit komt omdat er grote uitschieters in de data zitten, deze data zijn sterk scheef naar rechts. Figuur 9 laat de boxplot zien voor de 9 meetdagen voor het percentage vormvast PP in de gesorteerde kunststofstroom PE. We zien daar een zeer extreme uitbijter met ongeveer 20\%. Daarmee wordt deze verdeling zeer scheef naar rechts en komt dat tot uiting in de foutmarge aan de bovengrens. Er is dus een grotere kans op een hogere onzuiverheid, dan we met de normale verdeling hebben kunnen inschatten. De foutmarges berekend in tabel 1 zijn gebaseerd op symmetrische foutmarges voor boven- en ondergrens. Wanneer de verhouding in tabel 3 hoger wordt, zal de foutmarge voor de bovengrens groter zijn en voor de ondergrens kleiner zijn. Dit komt met name voor bij de criteria met lagere grenswaarden voor onzuiverheden. 


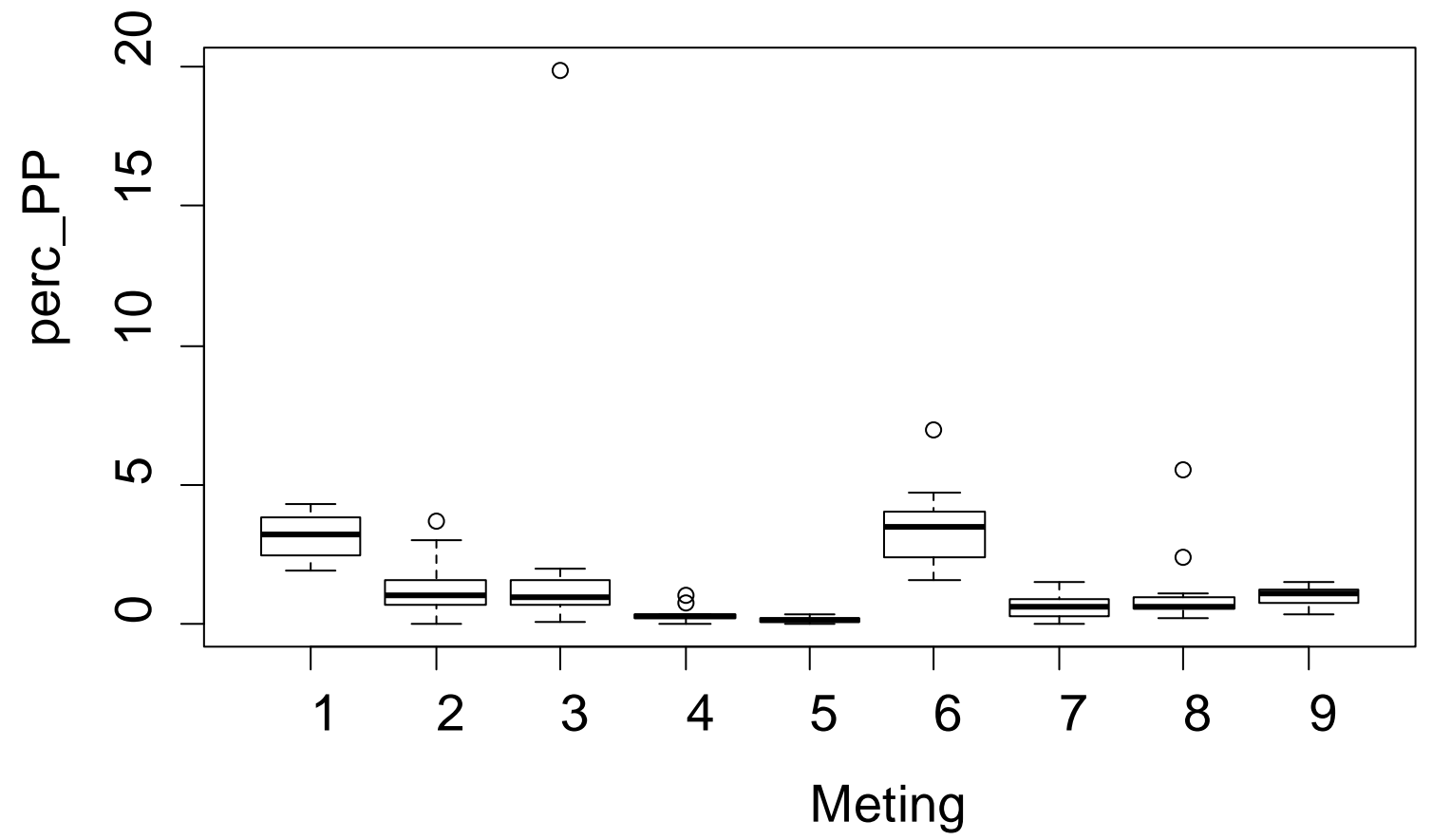

Figuur 9 Boxplots voor de 9 meetdagen voor het percentage vormvast PP in de gesorteerde kunststofstroom PE. 


\section{Discussie}

Dit onderzoek geeft inzicht in de nauwkeurigheid van metingen van de (on)zuiverheid in gesorteerde kunststofproducten en drankenkartons als resultaat van het aantal grepen. Per sorteerproduct (kunststofproduct of drankenkartons) zijn berekeningen gemaakt naar de invloed van het aantal grepen op de nauwkeurigheid van de bepaling van de kwaliteitscriteria in de DKR specificaties.

Wanneer er meer grepen worden genomen uit de aanwezige partij bij een sorteerinstallatie, neemt de nauwkeurigheid toe. In de praktijk zal het aantal grepen altijd een afweging zijn tussen de inspanning (kosten) die gemaakt worden en de gewenste nauwkeurigheid van de meting.

De berekende foutmarge verschilt per kwaliteitscriterium in de DKR specificatie. Daarbij moet in beschouwing worden genomen dat de gestelde maximale percentages in de DKR specificaties uit een kunnen lopen van $0,1 \%$ tot $10 \%$. In grote lijnen is dit ook terug te zien in de resultaten. Specificaties met een hoge maximale onzuiverheid hebben ook hogere foutmarges. Het is goed om bij de beoordelingen van de foutmarges hier rekening mee te houden. Dit zou kunnen door de relatieve fout uit te rekenen: de foutmarge gedeeld door de maximale waarde voor de DKR specificatie.

Per sorteerproduct kan het gewenste aantal grepen gekozen worden. Dit hoeft niet voor elk sorteerproduct een gelijk aantal te zijn. Sommige sorteerproducten zijn homogener dan andere wanneer we alle DKR specificaties per sorteerproduct vergelijken. Zo liggen de foutmarges (relatief) hoger bij het kunststofproduct Mix, dan bij het kunststofproduct PE. Bij 12 grepen en een foutmarge gebaseerd op alle sorteerinstallaties ligt de foutmarge voor PE onder de 1/3 van de maximale waarde voor de DKR specificatie (foutmarge/ DKR specificatie). Voor Mix, in het bijzonder voor restafval, ligt die verhouding veel hoger. Wanneer er voor een verschillend aantal grepen per meting wordt gekozen zou het logisch zijn om voor PE een lager aantal grepen te kiezen dan voor het kunststofproduct Mix.

De berekeningen in dit rapport zijn gemaakt onder de veronderstelling dat de data normaal verdeeld is. Het is belangrijk om dit te controleren. In de boxplots in bijlage B is te zien dat de data soms scheef naar rechts is. Dat betekent dat er grotere kans is op een hoge onzuiverheid, dan dat op basis van de normale verdeling te verwachten is.

Voor het criterium onzuiverheid worden voor bijna alle gesorteerde kunststofproducten geen hele grote afwijkingen van de normale verdeling gezien. Dit blijkt ook uit de Kolmogorov Smirnov toets (zie tabel 2). Voor andere criteria laat de Kolmogorov Smirnov toets wel afwijkingen zien van de normale verdeling. Deze toets is gedaan op de deelmetingen (samenvoeging van 4 grepen). Voor een beperkt gedeelte van de dataset ( 9 metingen over alle sorteerinstallaties) zijn ook alle kwaliteitsmetingen per greep gedaan. Dit gedeelte van de dataset geeft de mogelijkheid om de foutmarges te simuleren. De resultaten daarvan laten meestal zien dat bij 12 grepen per meting de foutmarge voor de bovengrens hoger is dan de foutmarge van de 
ondergrens. Met name als de gemeten percentages onzuiverheid lager worden, dichter bij nul liggen. De foutmarge voor het bepalen van de bovengrens wordt dus onderschat wanneer gebruik gemaakt van de symmetrie van de normale verdeling. Wanneer de verhouding tussen foutmarge ondergrens en bovengrens hoger worden, betekent dit dat de verdeling sterker scheef naar rechts is. Het meest extreme voorbeeld daarvan is gevisualiseerd in Figuur 9. Dit soort extreme waarden kunnen worden beschouwd als resultaten van een greep waarbij de procesvoering van een sorteerinstallatie niet op orde is. Men kan zich afvragen in hoeverre het reëel is deze waarnemingen mee te nemen in bovenstaande berekeningen. De resultaten van paragraaf 3.5.2. kunnen dan ook als een worst-case scenario worden gezien.

Het huidige aantal van 12 grepen per meting geeft voldoende nauwkeurigheid voor een meting. Bij deze analyse is verondersteld dat de data normaal verdeeld is. De gevonden niet-normaliteit van de data is vooral het gevolg van lage criteria-waarden en enkele uitschieters. Wanneer deze uitschieters worden meegenomen in de analyses (paragraaf 3.5.2) heeft dat nauwelijks invloed op de beslissing hoeveel grepen voldoende nauwkeurigheid opleveren voor een meting. Het nemen van meer dan 12 grepen per meting zal relatief weinig extra nauwkeurigheid opleveren. 


\section{Conclusies}

Het is van groot belang voor de monitoringsorganisatie Nedvang en alle

Raamovereenkomstpartijen (Vereniging Nederlandse Gemeenten (VNG), het verpakkende bedrijfsleven en de Rijksoverheid) dat de gesorteerde producten voldoen aan de hiervoor geldende kwaliteitscriteria (DKR specificaties). Het bepalen van de zuiverheid van de gesorteerde kunststofproducten gebeurt aan de hand van metingen die uitgevoerd worden conform het "Meetprotocol samenstelling kunststofverpakkingsafval en drankenkartons afkomstig uit huishoudens" (Nedvang, 2016). Centrale vraag in dit rapport is of het huidig aantal van 12 grepen per meting voldoende nauwkeurig is voor de meetresultaten van deze kwaliteitsmetingen. Daarnaast wordt de invloed van het aantal grepen per meting op het jaargemiddelde bepaald. Tenslotte is additioneel onderzoek gedaan naar de aanname van normaal verdeelde data. Samenvattend zijn de volgende conclusies te trekken:

- Het huidige aantal van 12 grepen per meting geeft een voldoende nauwkeurigheid voor een meting. Meer grepen per meting levert relatief weinig extra nauwkeurigheid op.

- Het aantal grepen per meting heeft een beperkte invloed op het berekenen van het jaargemiddelde.

- De foutmarges berekend in tabel 1 zijn gebaseerd op symmetrische foutmarges voor de boven- en ondergrens. De foutmarge voor de bovengrens wordt onderschat wanneer de verdeling scheef naar rechts is. Dit komt met name voor bij de criteria met lagere grenswaarden voor onzuiverheden. Bijvoorbeeld percentage metaal waar het DKR criterium voor de meeste gesorteerde producten dicht bij nul ligt, namelijk 0.5 procent.

Zoals in paragraaf 1.2 aangegeven focust deze studie zich op de nauwkeurigheid van de fractie onzuiverheid per meting als resultaat van het aantal grepen per meting. Bovenstaande conclusies kunnen niet één op één worden toegepast op het onderzoek naar variatie tussen metingen per sorteerinstallatie, zoals relevant in de beoordelingssystematiek(Cyclos, 2016). 


\section{Referenties}

Cyclos, 2016, "Controlesysteem voor kunststofverpakkingsafval en drankenkartons afkomstig van huishoudens, Beoordelingssystematiek voor de verwerking van resultaten van metingen van de fysieke samenstelling", https://www.nedvang.nl/uploads/Beoordelingssystematiek kunststofverpakkingsafval en dran kenkartons.pdf

Nedvang, 2016, "Meetprotocol samenstelling kunststofverpakkingsafval en drankenkartons afkomstig uit huishoudens", https://www.nedvang.nl/uploads/Meetprotocol kunststofverpakkingsafval en drankenkartons. pdf 


\section{Bijlagen}

Bijlage A: Tabellen van foutmarges voor de andere kunststofstromen (PE, PP, PET, Folie) en drankenkartons in [\%].

Bijlage B: Alle figuren voor de 5 kunststofproducten en drankenkartons.

Bijlage C: Review report: “2nd Opinion on the report” June 2017

Bijlage D: Reactie op de review "2nd Opinion on the report” June 2017 
Tabellen van foutmarges voor de andere kunststofstromen (PE, PP, PET, Folie) en drankenkartons in [\%].

\begin{tabular}{|c|c|c|c|c|c|c|c|}
\hline PE & grepen & Onzuiverheid & restafval & perc_Folies & perc_Vormvast_PP & perc_Geexpandeerd_kunststof & perc_metal \\
\hline \multirow[t]{3}{*}{ alle } & 8 & 2.30 & 0.87 & 1.25 & 0.85 & 0.06 & 0.12 \\
\hline & 12 & 1.88 & 0.71 & 1.02 & 0.69 & 0.05 & 0.10 \\
\hline & 16 & 1.63 & 0.61 & 0.88 & 0.60 & 0.04 & 0.08 \\
\hline \multirow[t]{3}{*}{ top drie } & 8 & 1.59 & 0.63 & 1.12 & 0.45 & 0.08 & 0.06 \\
\hline & 12 & 1.30 & 0.51 & 0.91 & 0.37 & 0.06 & 0.05 \\
\hline & 16 & 1.12 & 0.45 & 0.79 & 0.32 & 0.05 & 0.04 \\
\hline \multicolumn{2}{|c|}{ DKR criteria } & 6 & 3 & 5 & 3 & 0.5 & 0.5 \\
\hline
\end{tabular}

\begin{tabular}{|l|c|c|c|c|c|c|c|}
\hline PP & grepen & Onzuiverheid & restafval & per__Folies & per__Vormvast_PE & perc_Geexpandeerd_kunststof & perc_metal \\
\hline alle & 8 & 2.82 & 1.92 & 1.58 & 0.88 & 0.05 \\
\hline & 12 & 2.30 & 1.56 & 1.29 & 0.72 & 0.04 \\
\hline & 16 & 1.99 & 1.35 & 1.12 & 0.62 & 0.04 \\
\hline top drie & 8 & 1.76 & 0.92 & 1.30 & 0.64 & 0.29 \\
\hline & 12 & 1.44 & 0.75 & 1.06 & 0.52 & 0.03 & 0.02 \\
\hline & 16 & 1.25 & 0.65 & 0.92 & 0.45 & 0.16 \\
\hline DKR criteria & & $\mathbf{6}$ & $\mathbf{3}$ & $\mathbf{2}$ & $\mathbf{1}$ & 0.11 \\
\hline
\end{tabular}

\begin{tabular}{|c|c|c|c|c|c|c|c|}
\hline PET & grepen & Onzuiverheid & restafval & perc_not_PET_bottles & perc_PET_other & perc_other_plastic & perc_metal \\
\hline \multirow[t]{3}{*}{ alle } & 8 & 1.29 & 0.63 & 3.41 & 2.58 & 0.79 & 0.07 \\
\hline & 12 & 1.05 & 0.51 & 2.79 & 2.11 & 0.65 & 0.06 \\
\hline & 16 & 0.91 & 0.45 & 2.41 & 1.83 & 0.56 & 0.05 \\
\hline \multirow[t]{3}{*}{ top drie } & 8 & 0.67 & 0.18 & 2.58 & 2.27 & 0.62 & 0.06 \\
\hline & 12 & 0.55 & 0.14 & 2.11 & 1.85 & 0.50 & 0.05 \\
\hline & 16 & 0.47 & 0.13 & 1.82 & 1.60 & 0.44 & 0.05 \\
\hline \multicolumn{2}{|c|}{ DKR criteria } & 2 & 2 & 10 & 10 & 2 & 0.5 \\
\hline
\end{tabular}

* PVC is niet meegenomen in deze analyse, omdat PVC nauwelijks voorkomt in de dataset en het hierdoor moeilijk te modelleren is. Van de 88 monsters PET die in de dataset zitten is PVC 71 keer afwezig ( 0 waarde). Maximaal zit er 0.09 kilogram PVC in de PET-fractie in een deelmeting (zo'n 80-90 kilogram bij elkaar).

\begin{tabular}{|l|c|c|c|c|c|}
\hline Folie & grepen & Onzuiverheid & restafval & perc_ander_kunststof & perc_metal \\
\hline alle & 8 & 3.00 & 1.84 & 2.01 & 0.19 \\
\hline & 12 & 2.45 & 1.50 & 1.64 & 0.16 \\
\hline & 16 & 2.12 & 1.30 & 1.42 & 0.14 \\
\hline & & & & & \\
\hline & 8 & 1.90 & 0.92 & 1.37 & 0.19 \\
\hline & 12 & 1.55 & 0.75 & 1.12 & 0.15 \\
\hline & 16 & 1.35 & 0.65 & 0.97 & 0.13 \\
\hline DKR criteria & & $\mathbf{8}$ & $\mathbf{4}$ & $\mathbf{4}$ & $\mathbf{0 . 5}$ \\
\hline
\end{tabular}

\begin{tabular}{|l|c|c|c|c|c|c|}
\hline Drankenkartons & grepen & Onzuiverheid & restafval & perc_papier & perc_kunststof & perc_metal \\
\hline alle & 8 & 2.62 & 0.55 & 1.96 & 1.02 & 0.19 \\
\hline & 12 & 2.14 & 0.45 & 1.60 & 0.84 & 0.16 \\
\hline & 16 & 1.85 & 0.39 & 1.39 & 0.72 & 0.14 \\
\hline & & & & & & \\
\hline & 8 & 1.27 & 0.62 & 0.81 & 0.73 & 0.16 \\
\hline & 12 & 1.04 & 0.50 & 0.66 & 0.59 & 0.13 \\
\hline & 16 & 0.90 & 0.44 & 0.57 & 0.51 & 0.11 \\
\hline & & $\mathbf{1 0}$ & $\mathbf{3}$ & $\mathbf{2 . 5}$ & $\mathbf{4}$ & $\mathbf{0 . 5}$ \\
\hline
\end{tabular}


Mix
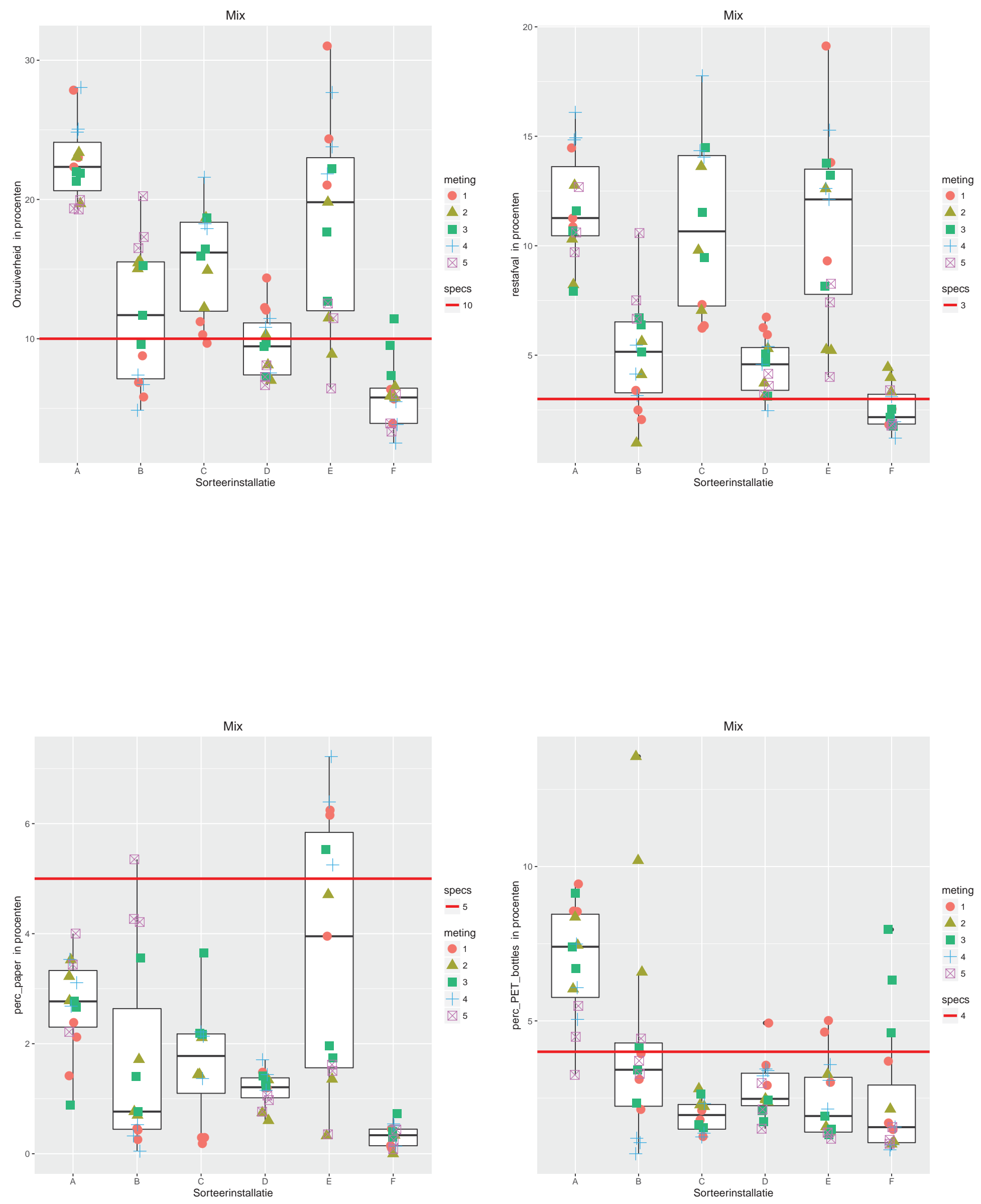

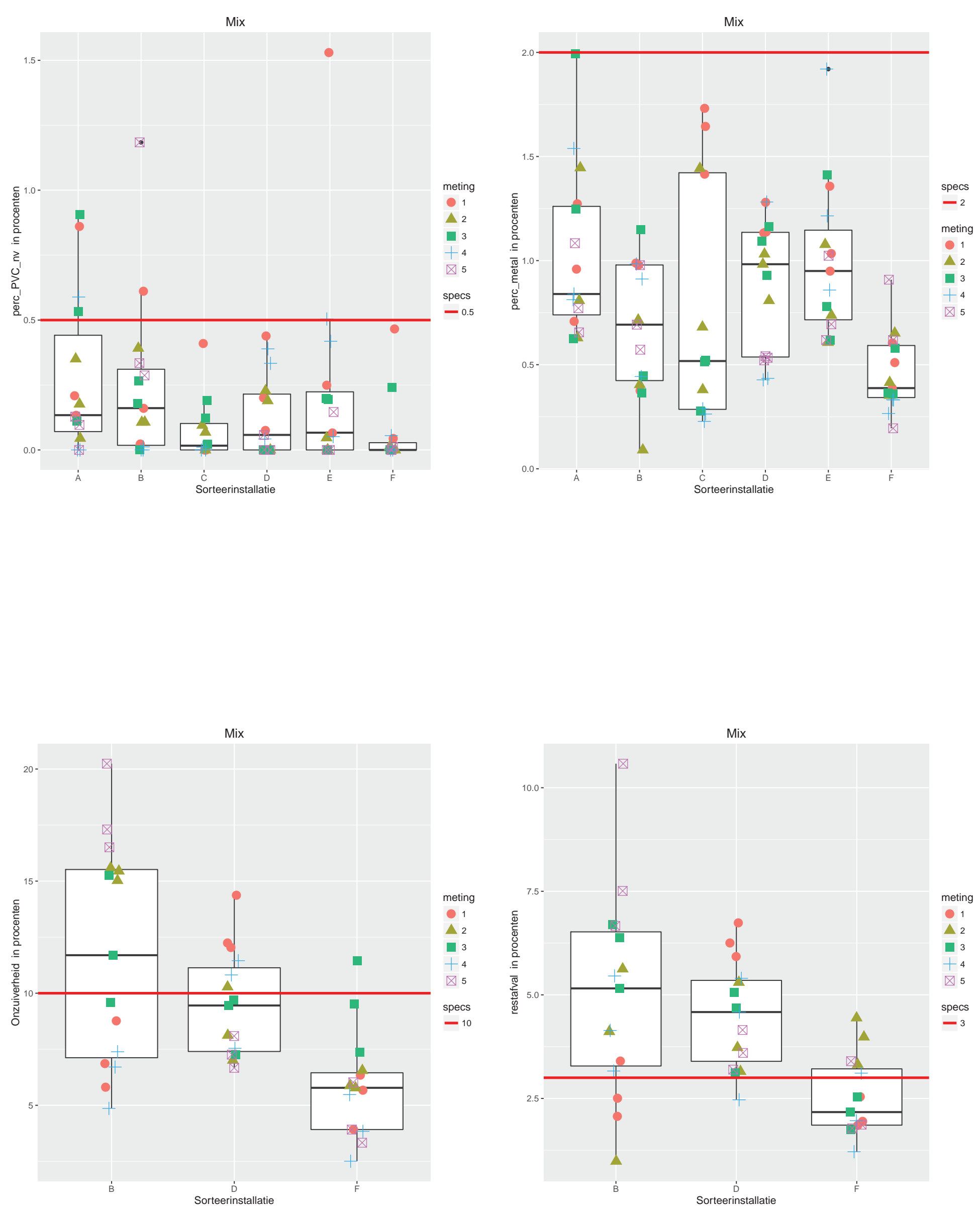
Mix

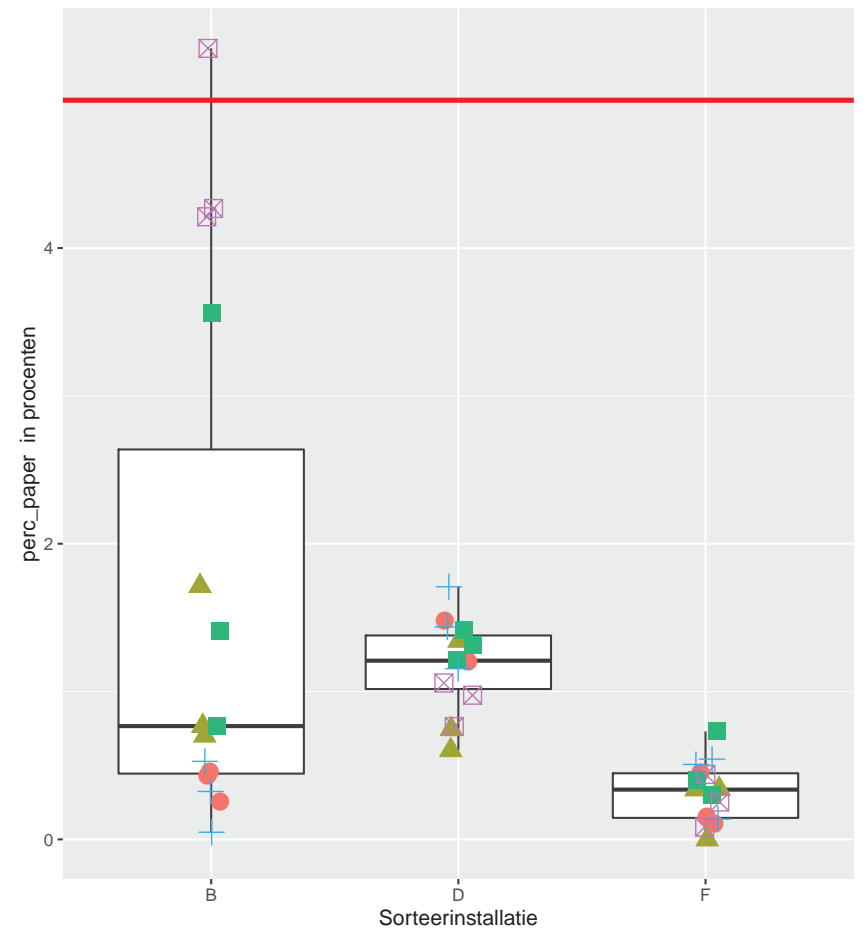

Mix

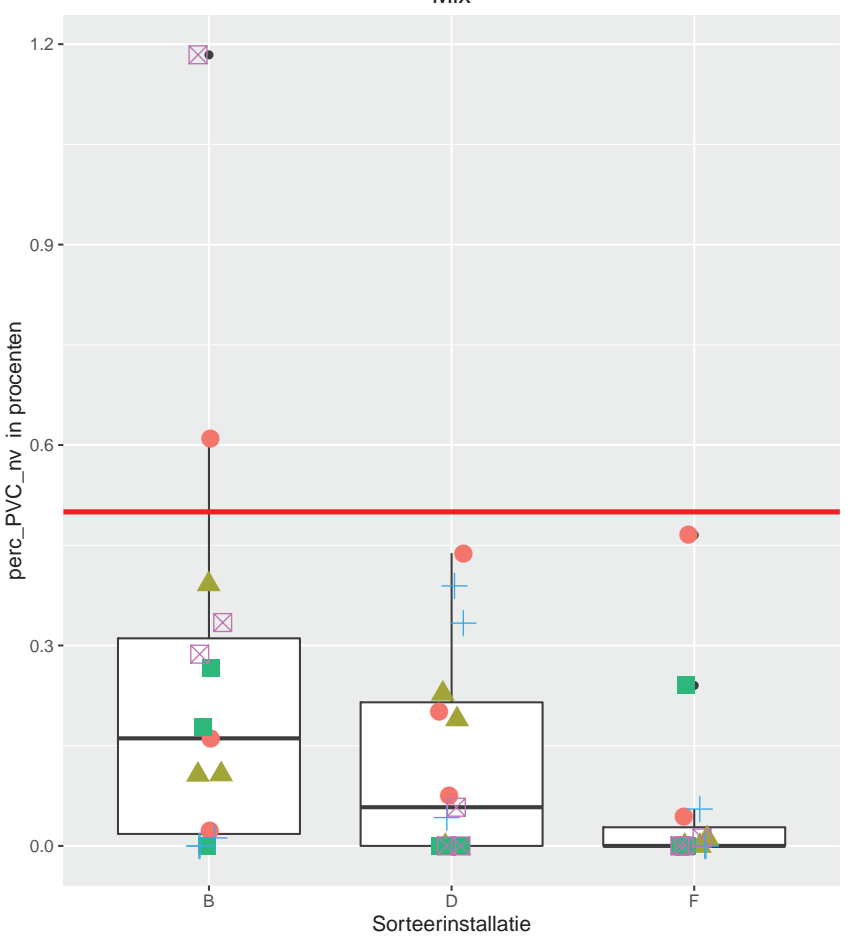

Mix
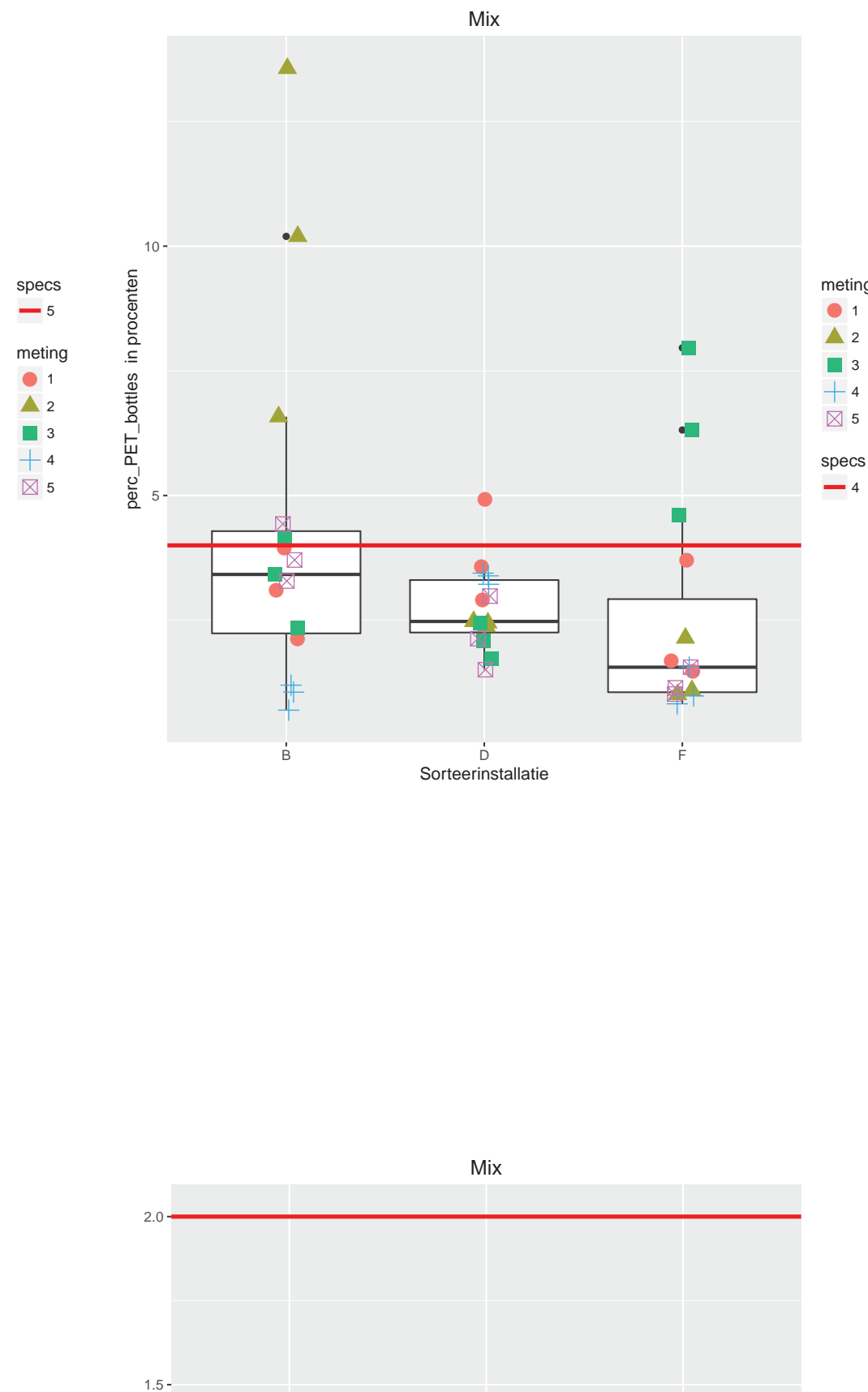

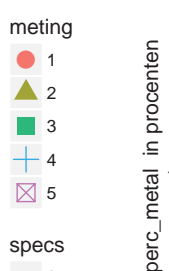

$0.5-$
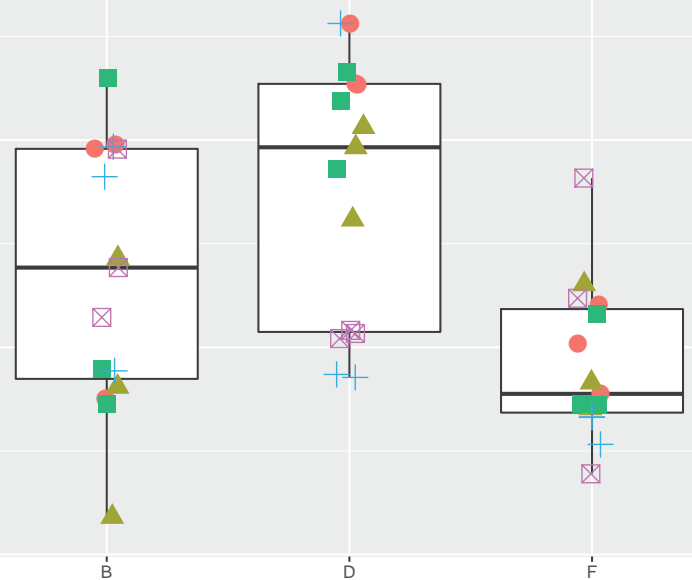

specs

meting

- 1

2

- 3

$-4$

\5 

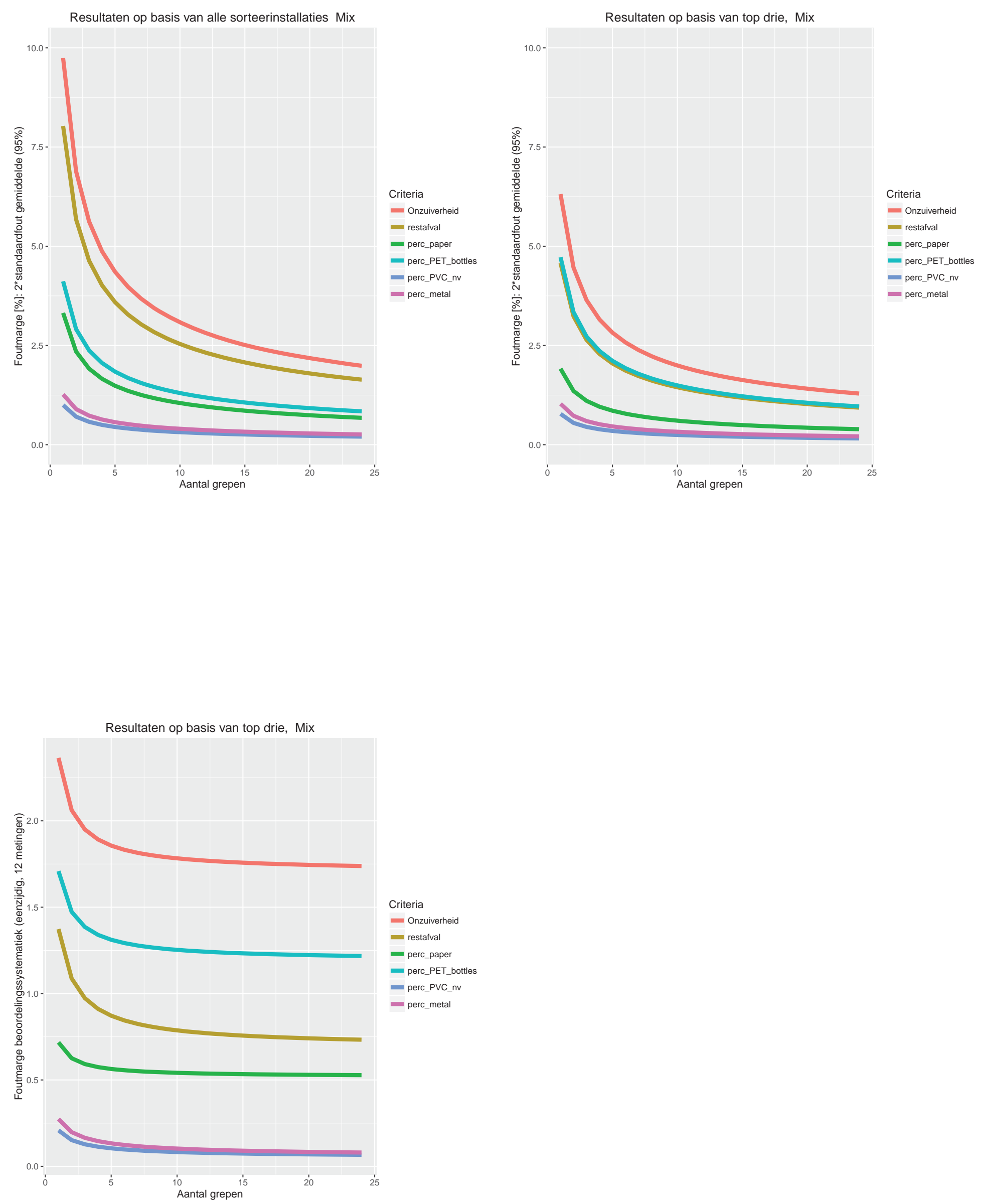

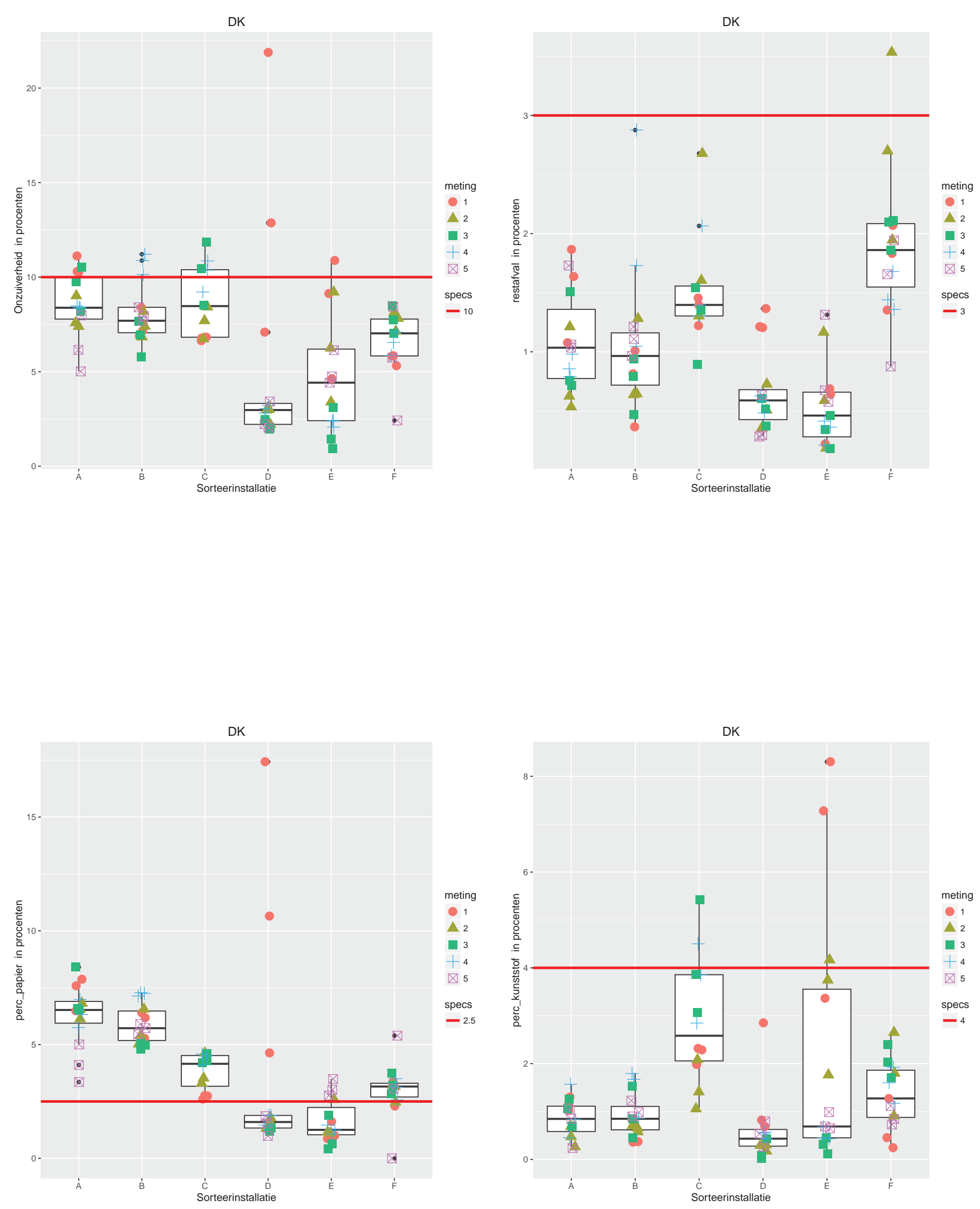
DK

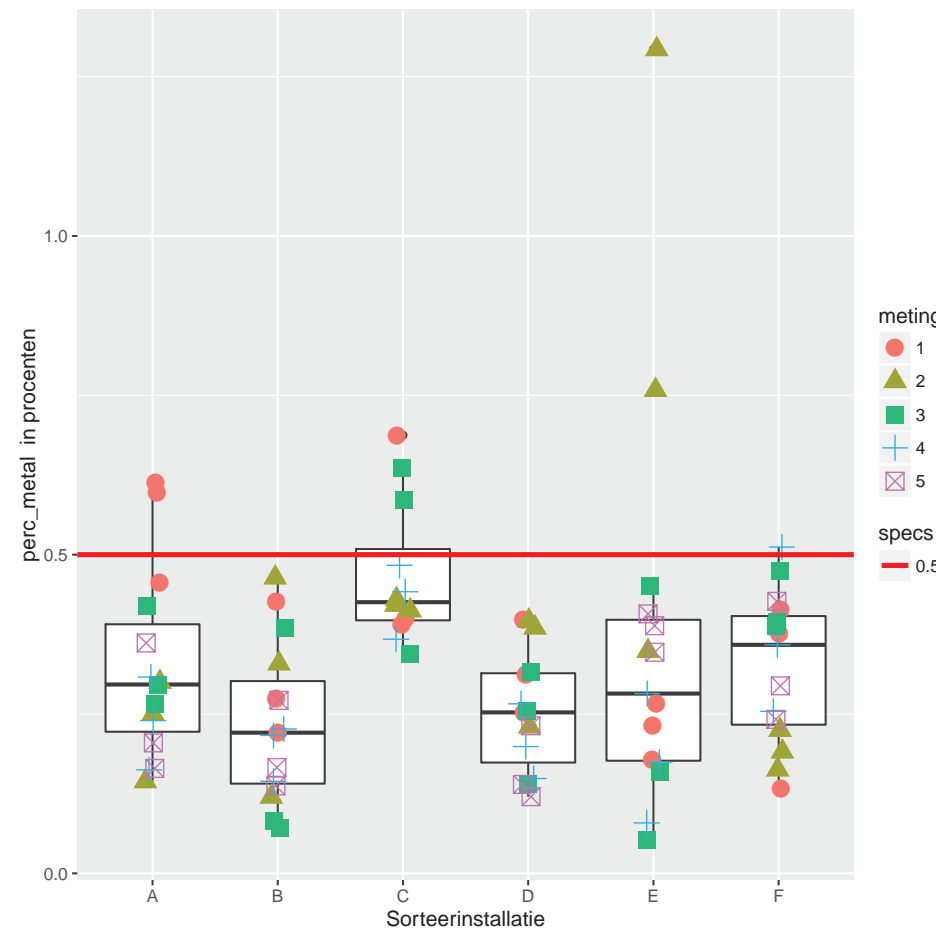

DK

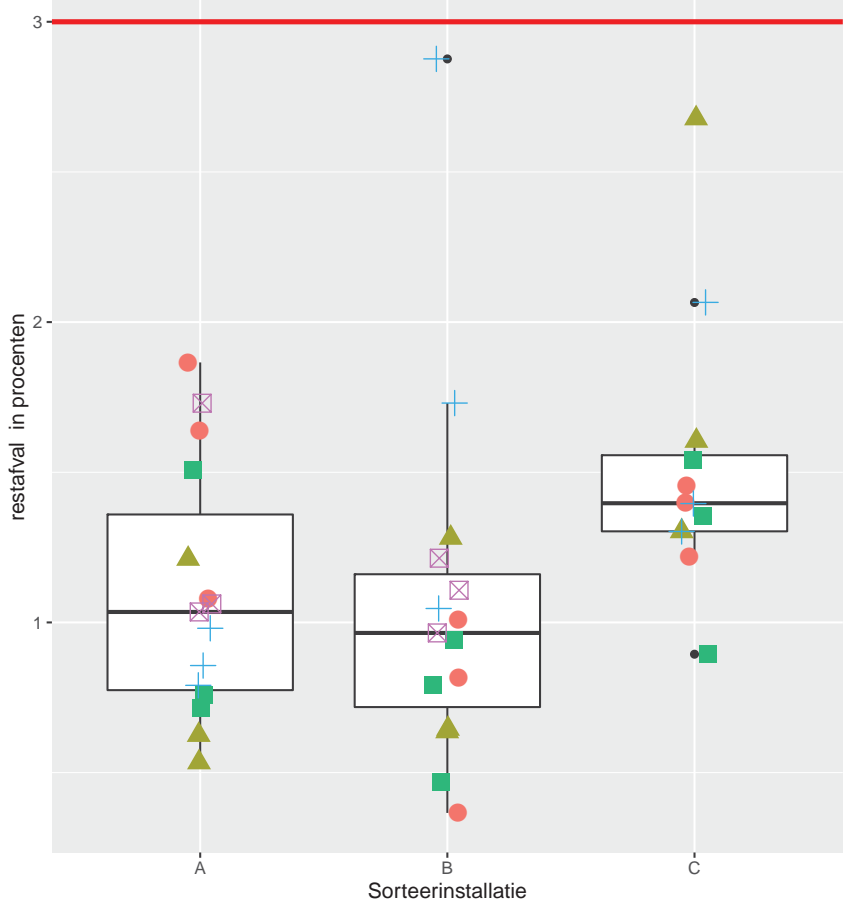

DK

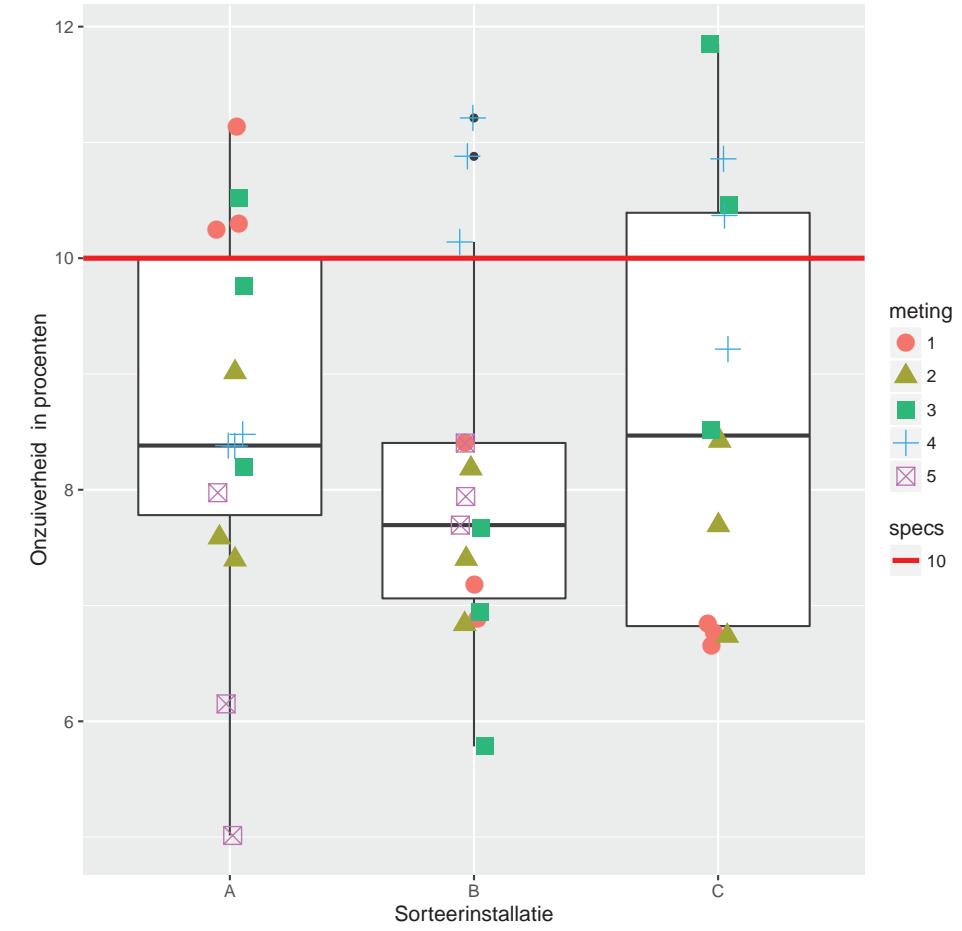

DK

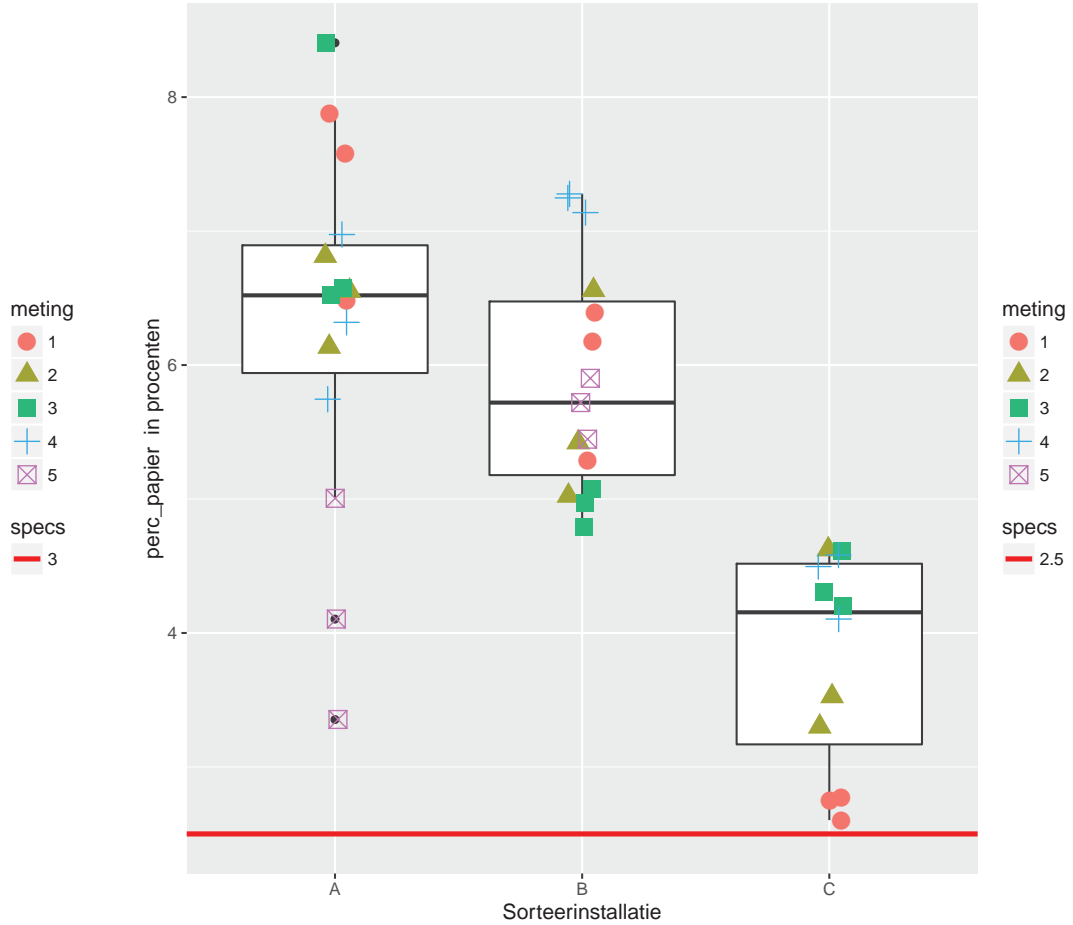


DK

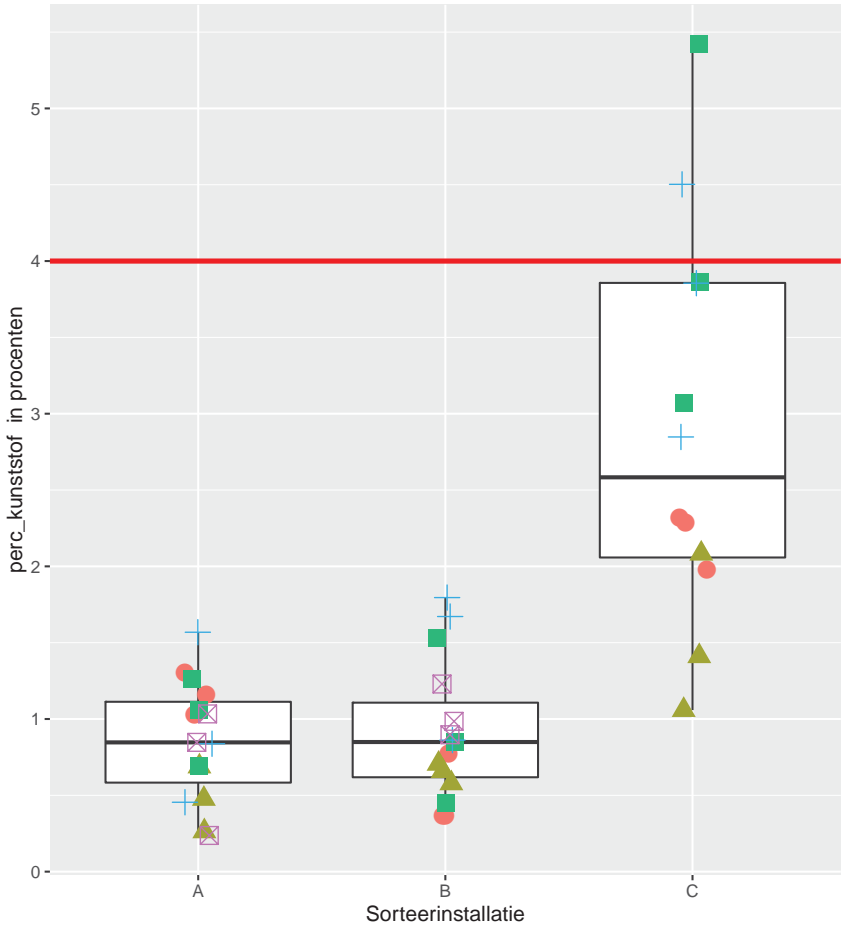

Resultaten op basis van alle sorteerinstallaties, DK

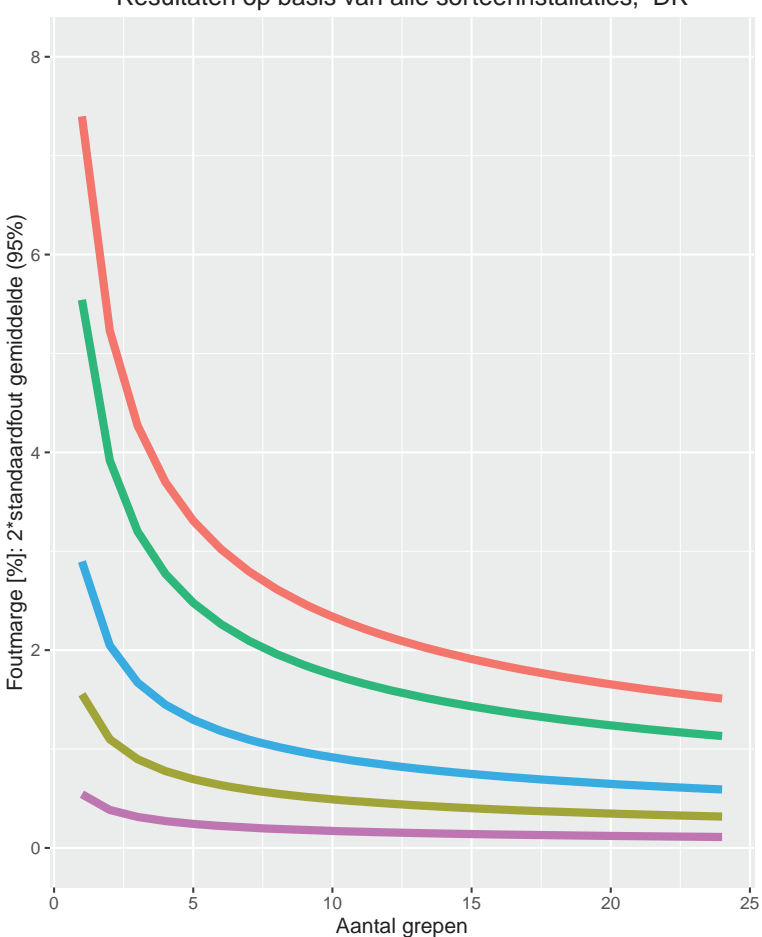

DK

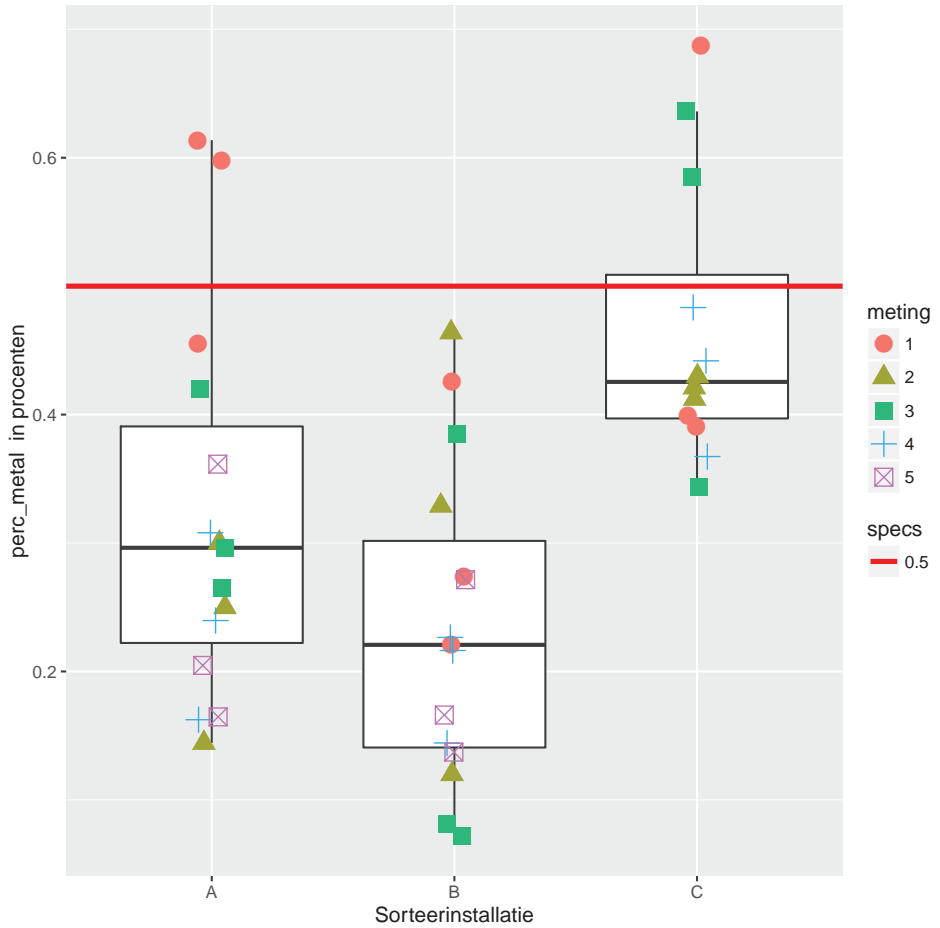

Resultaten op basis van top drie, DK

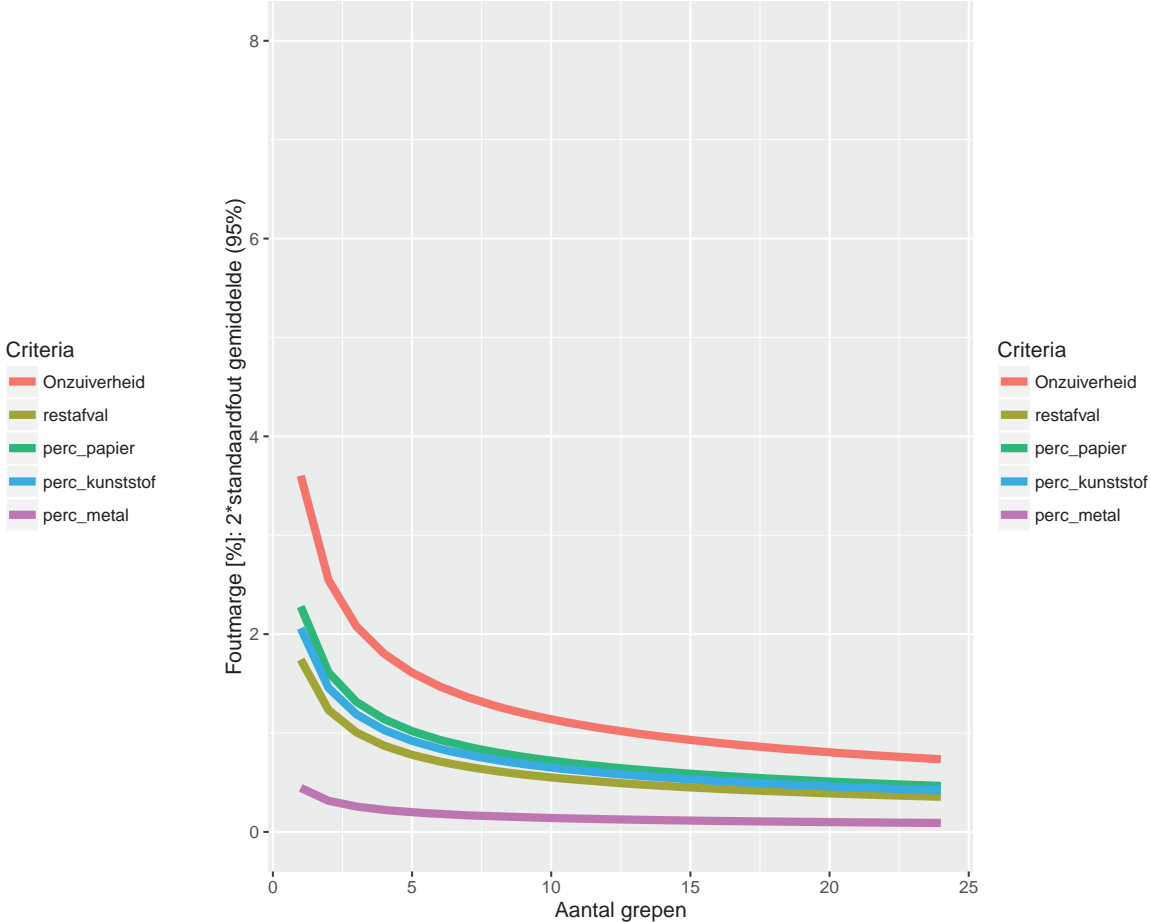




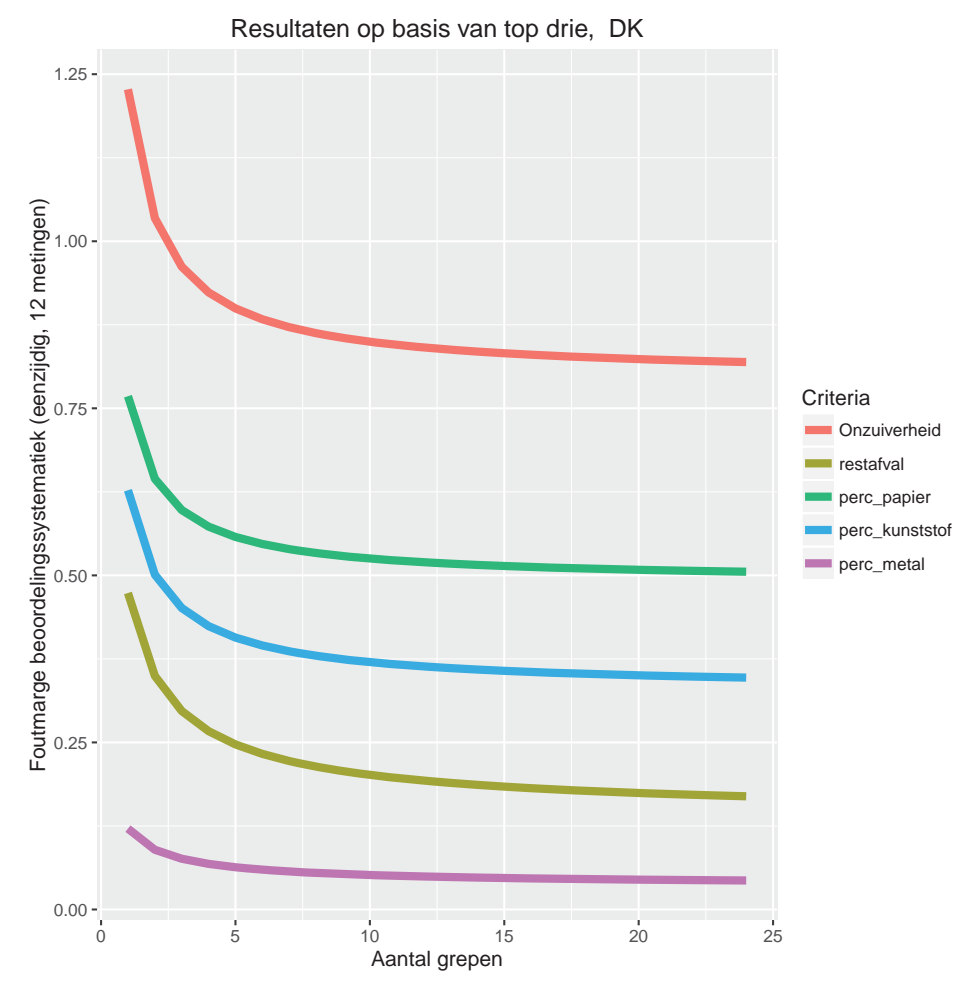



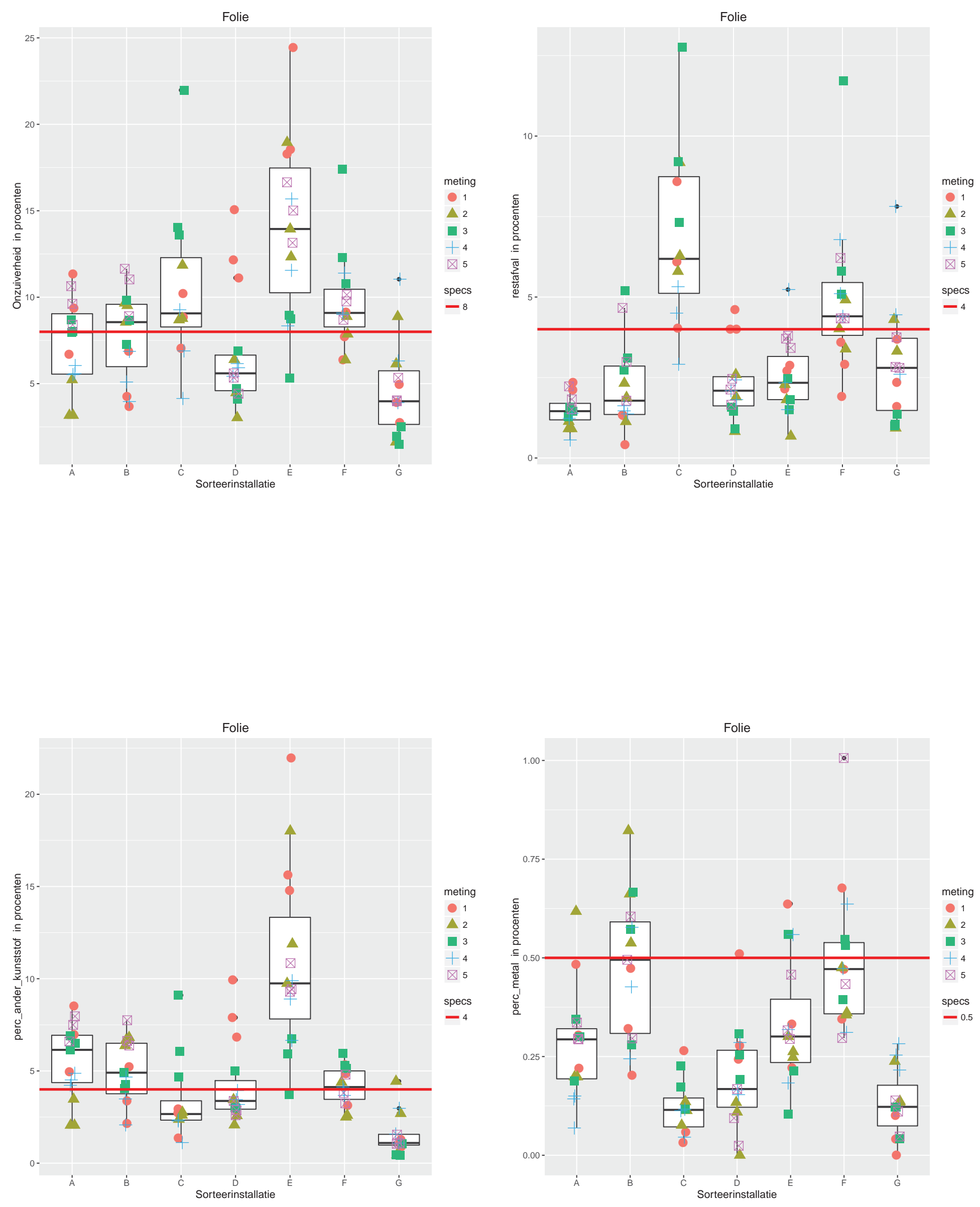

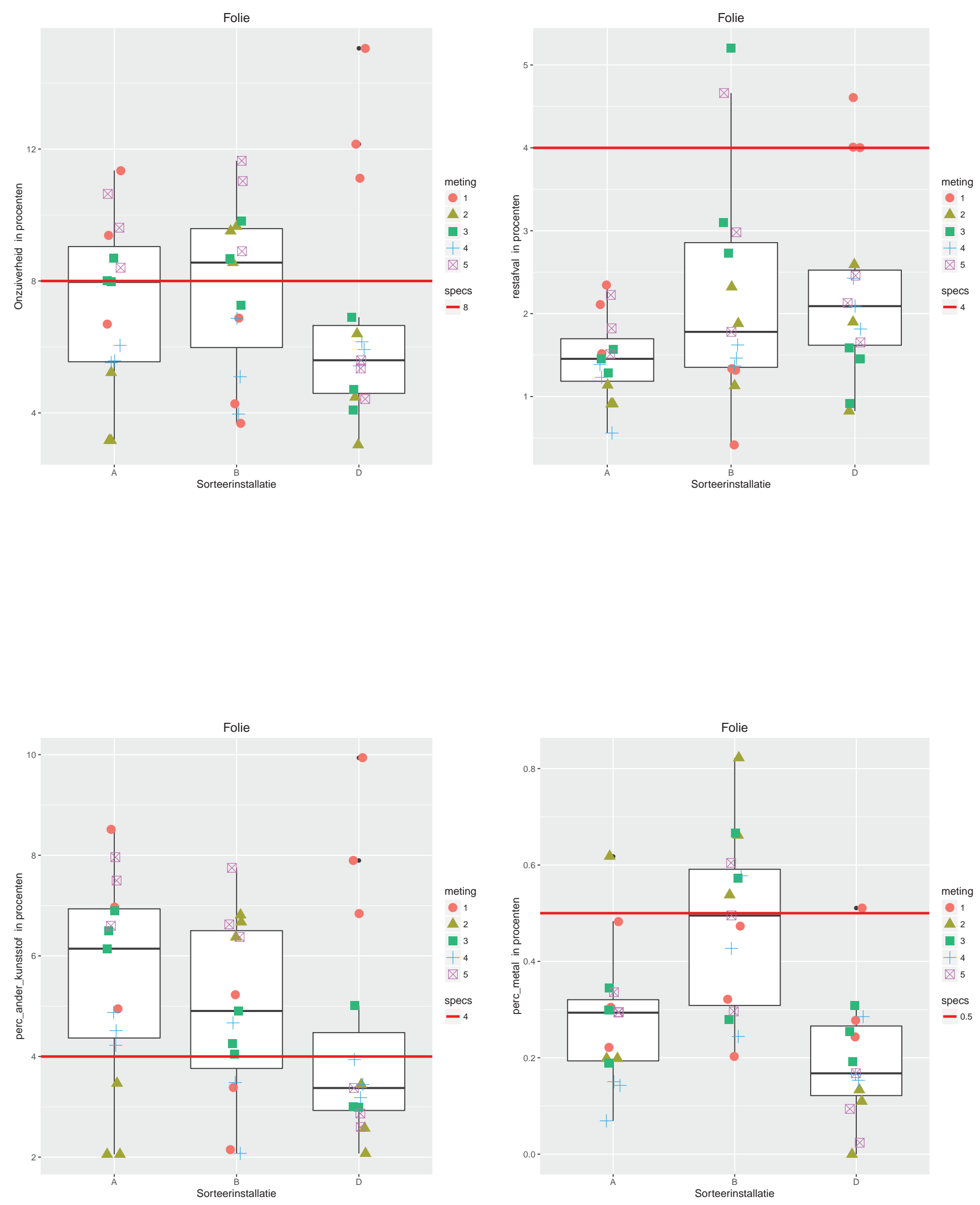
Resultaten op basis van alle sorteerinstallaties, Folie
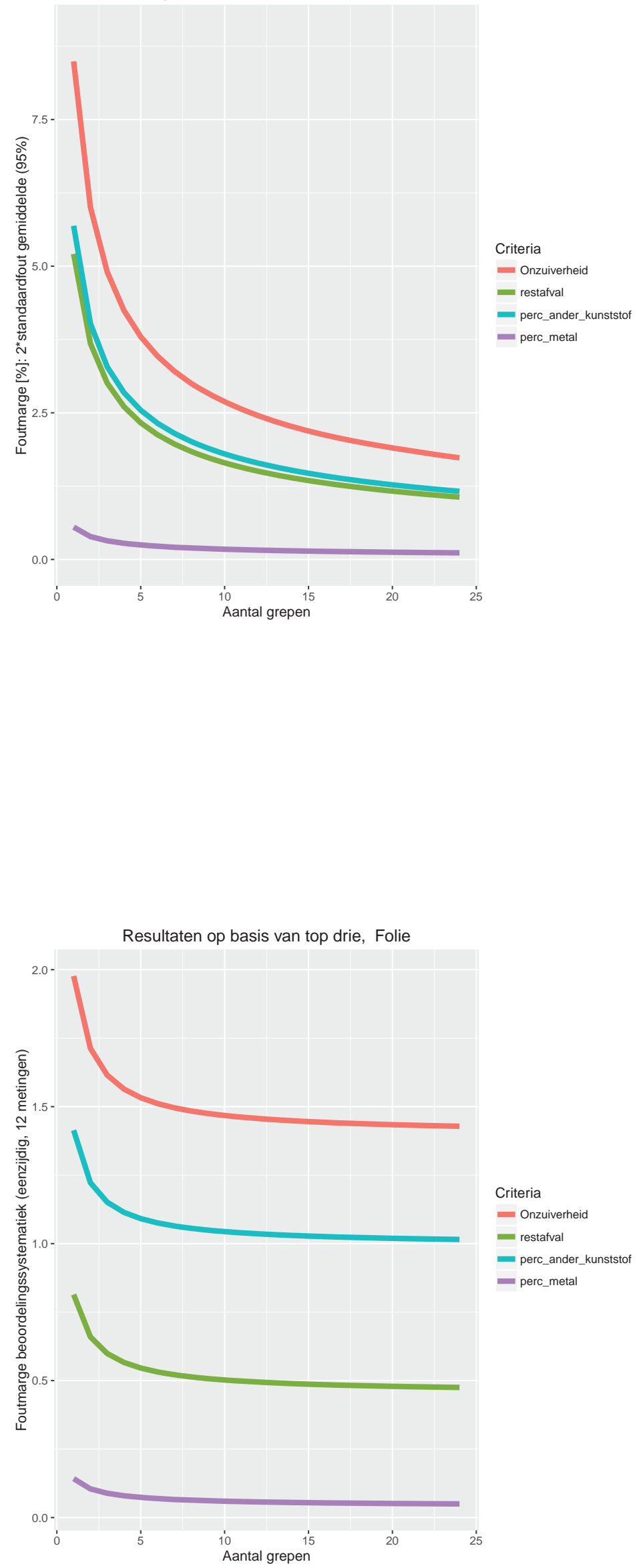

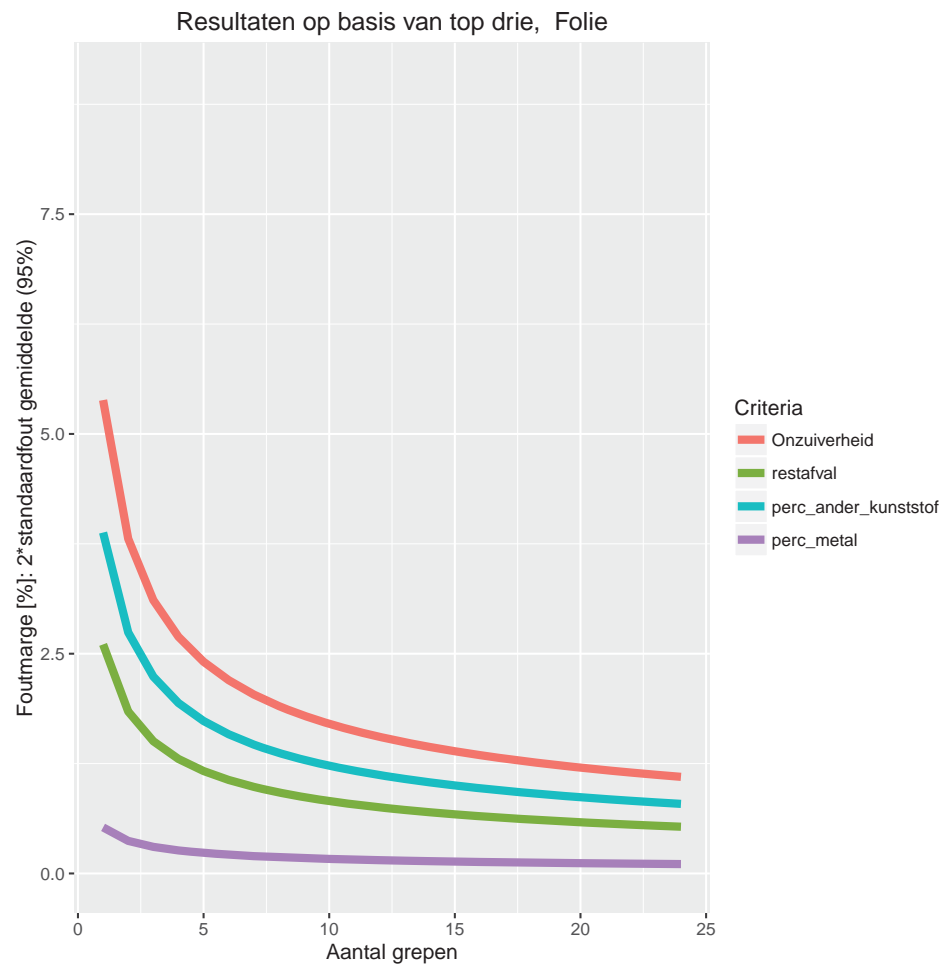

Criteria

- Onzuiverheid

- restafval

- perc_ander_kunststo

- perc_metal

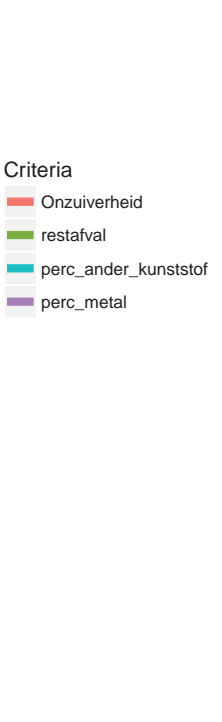

Onzuiverheid

restafva

- perc_ander_kunststof

perc_meta 
PE

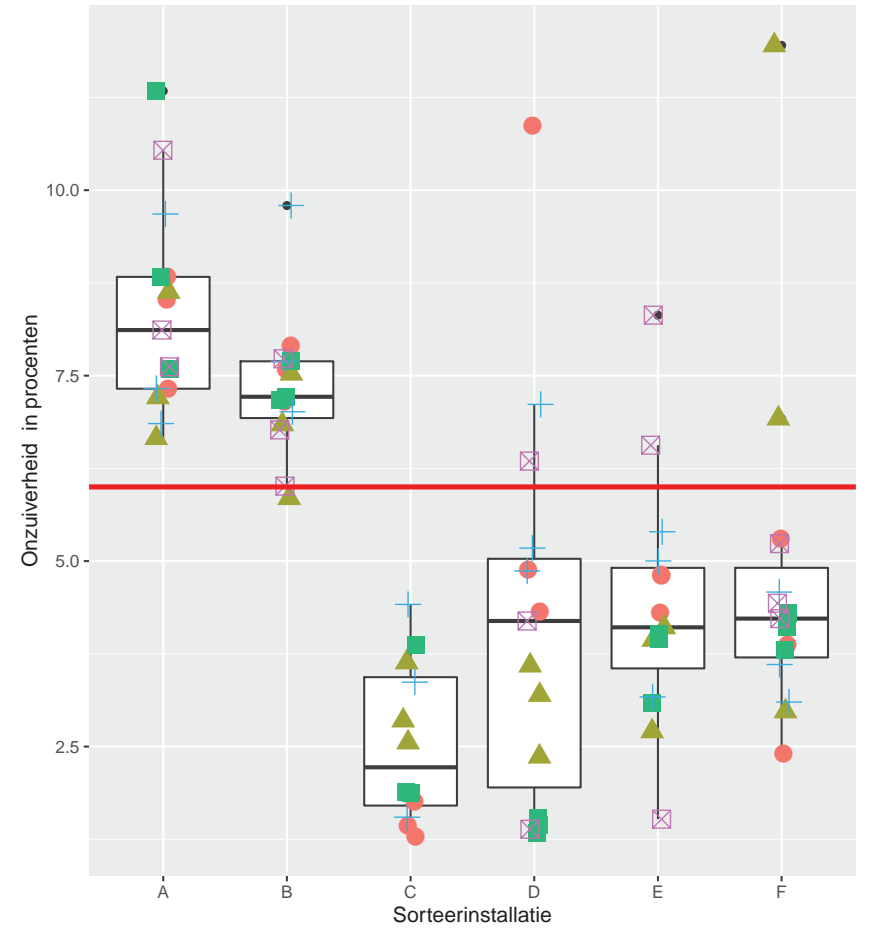

PE
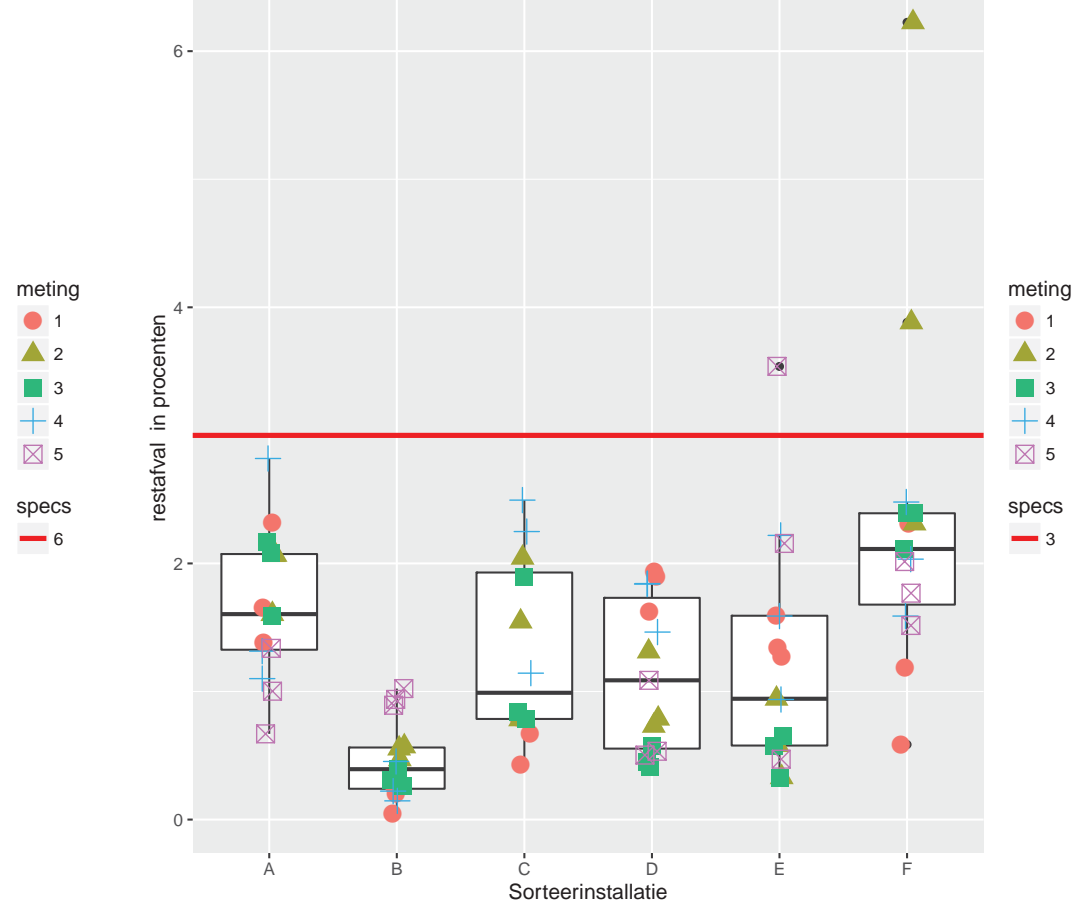

PE

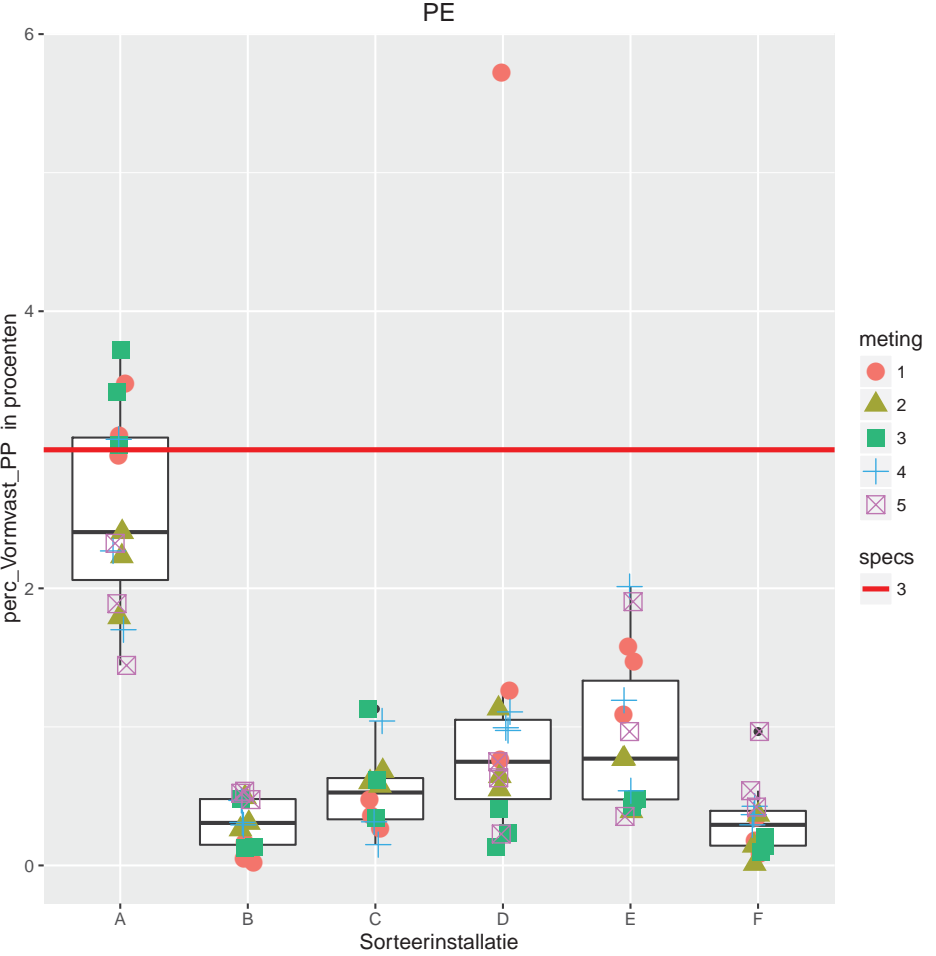


PE

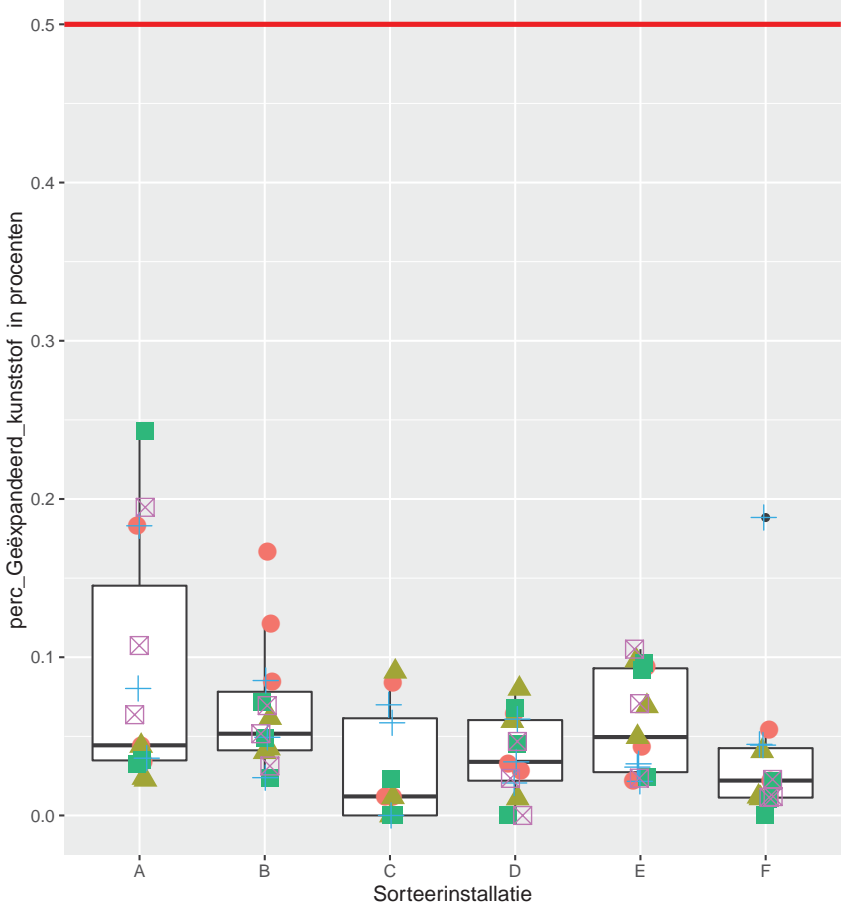

PE

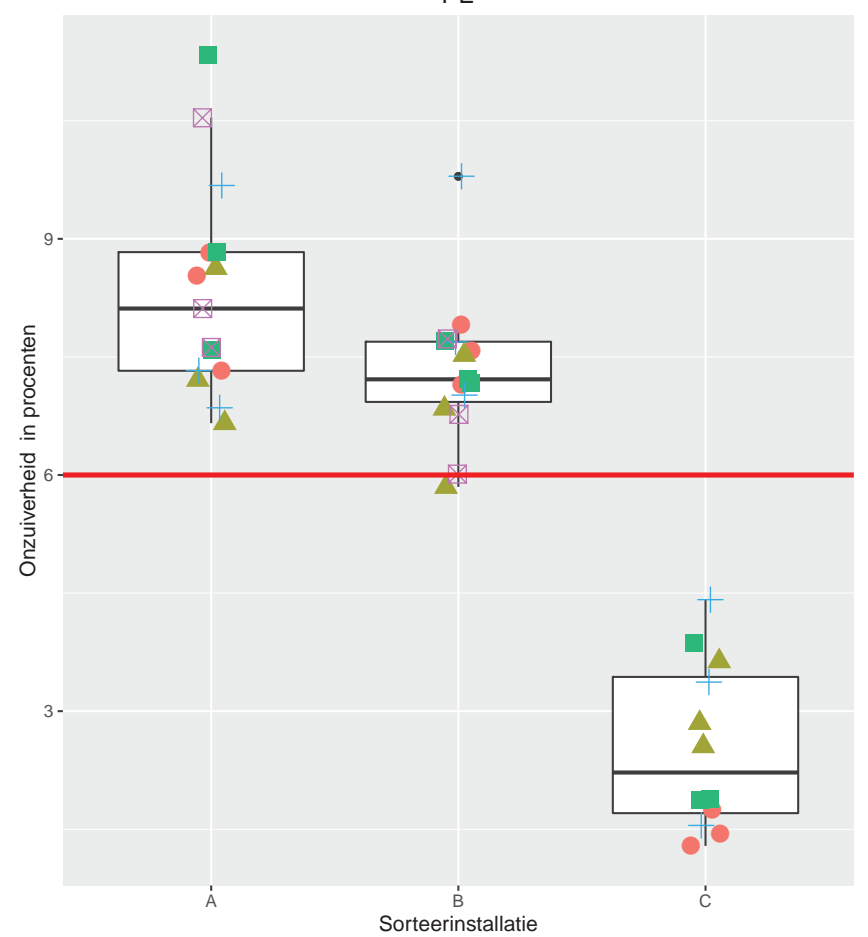

PE

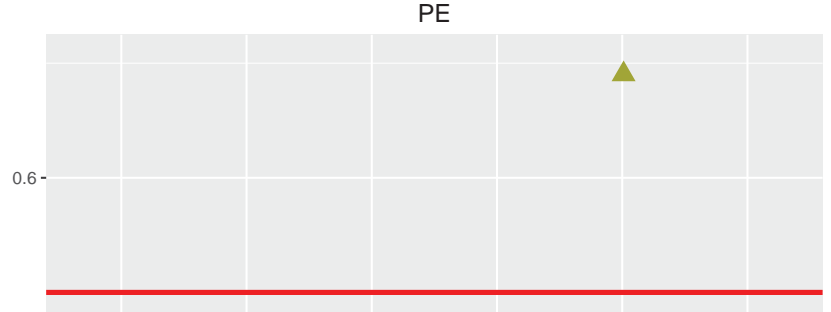

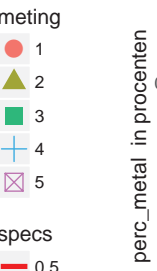

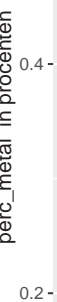

meting

1

$\Delta 2$

- 3

$+4$

$\triangle 5$

specs

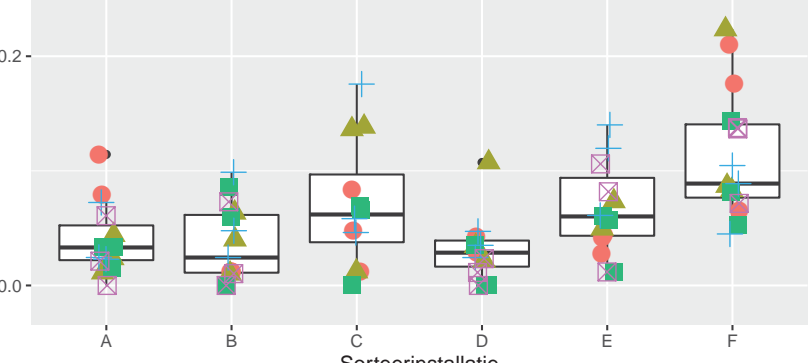

$-0.5$
PE

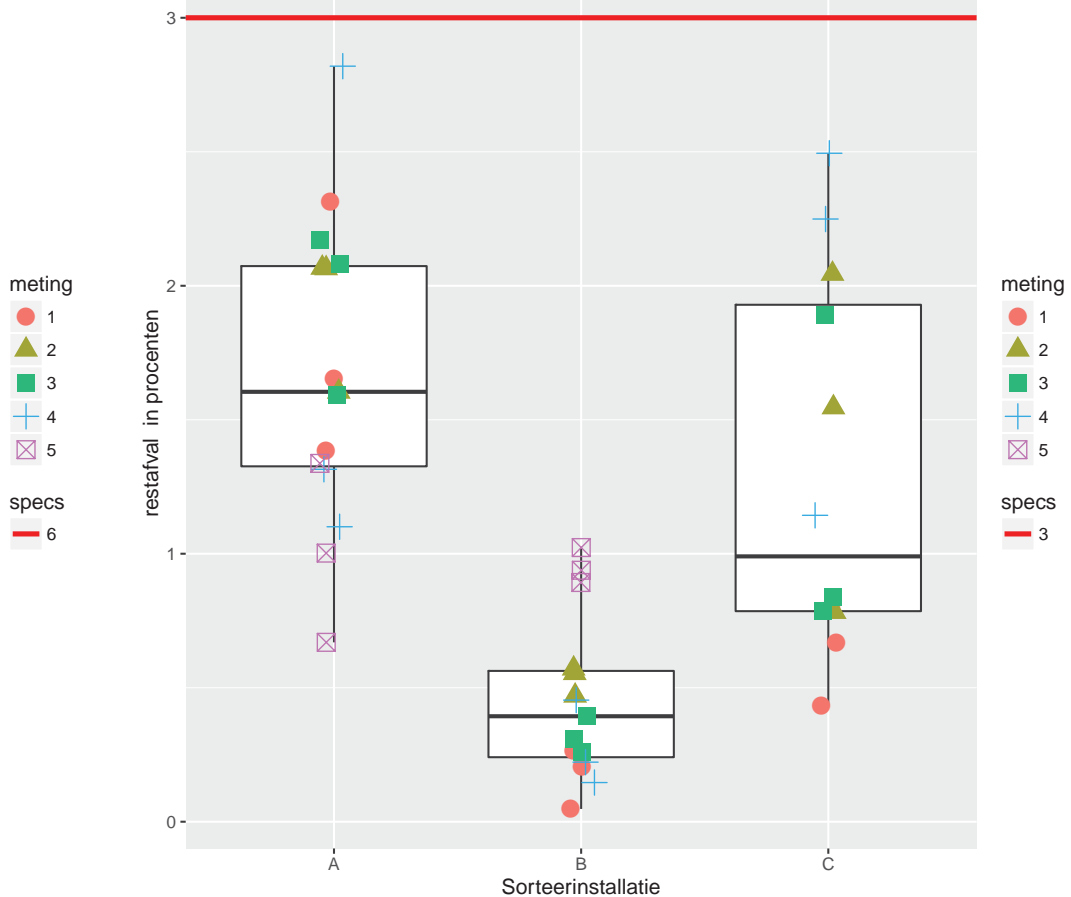



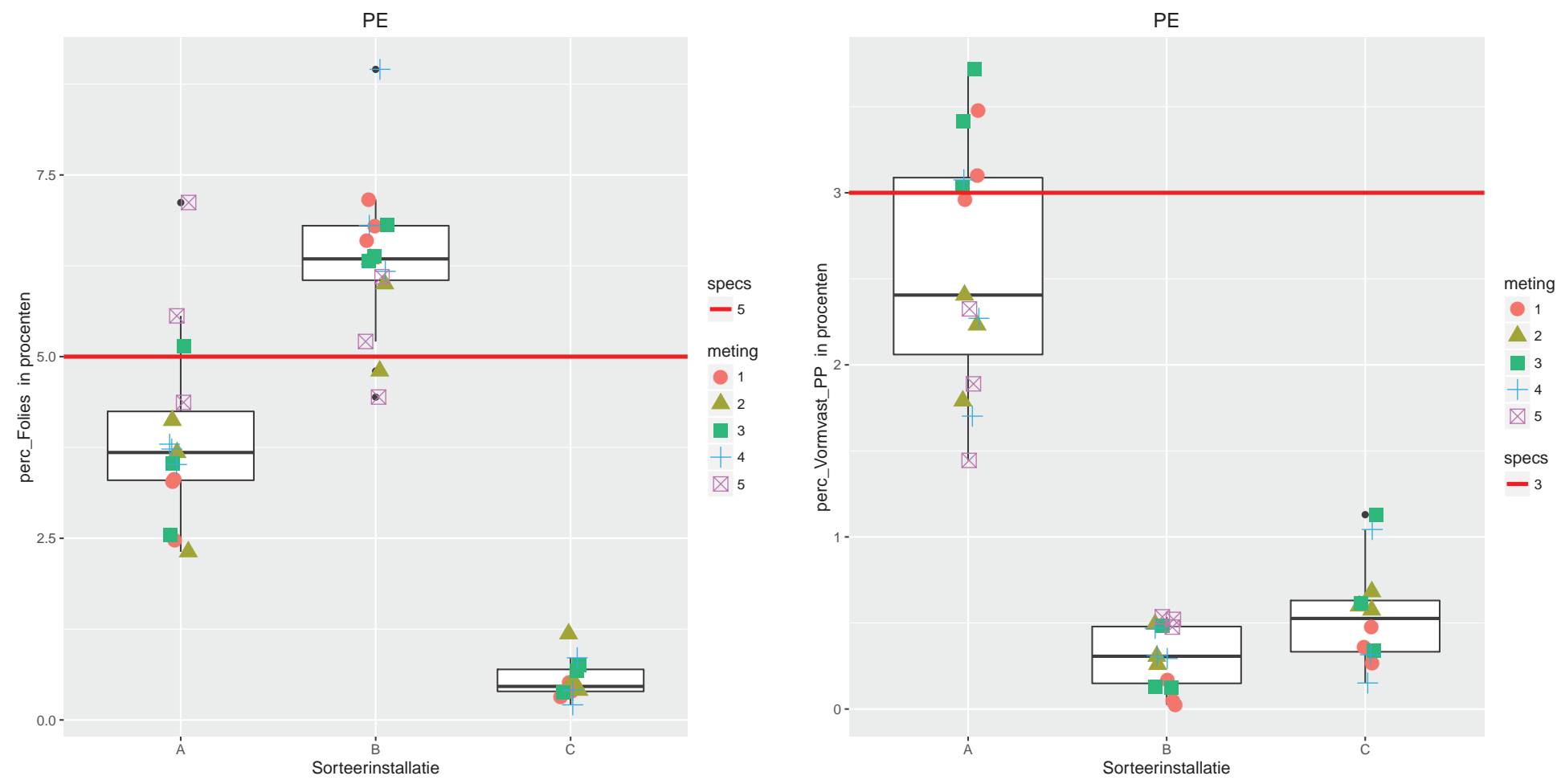

PE

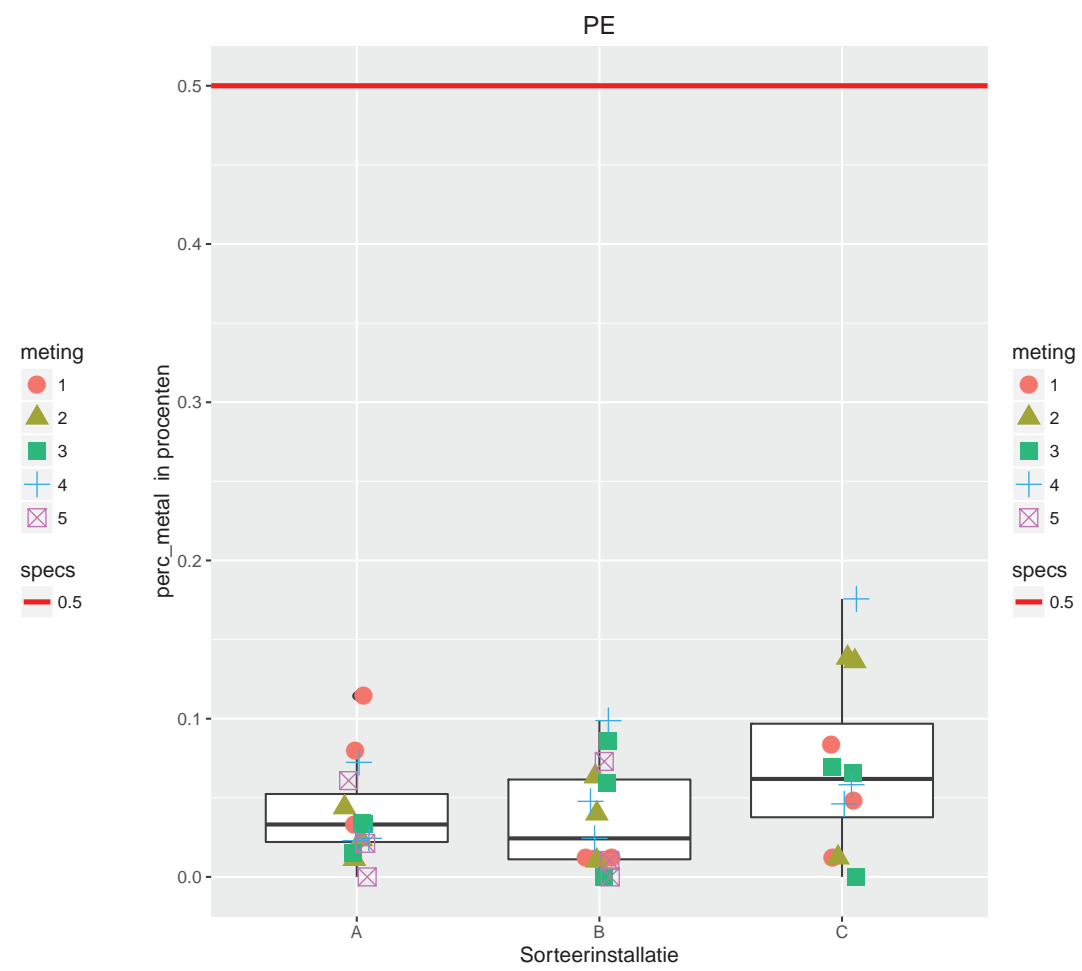


Resultaten op basis van alle sorteerinstallaties, PE
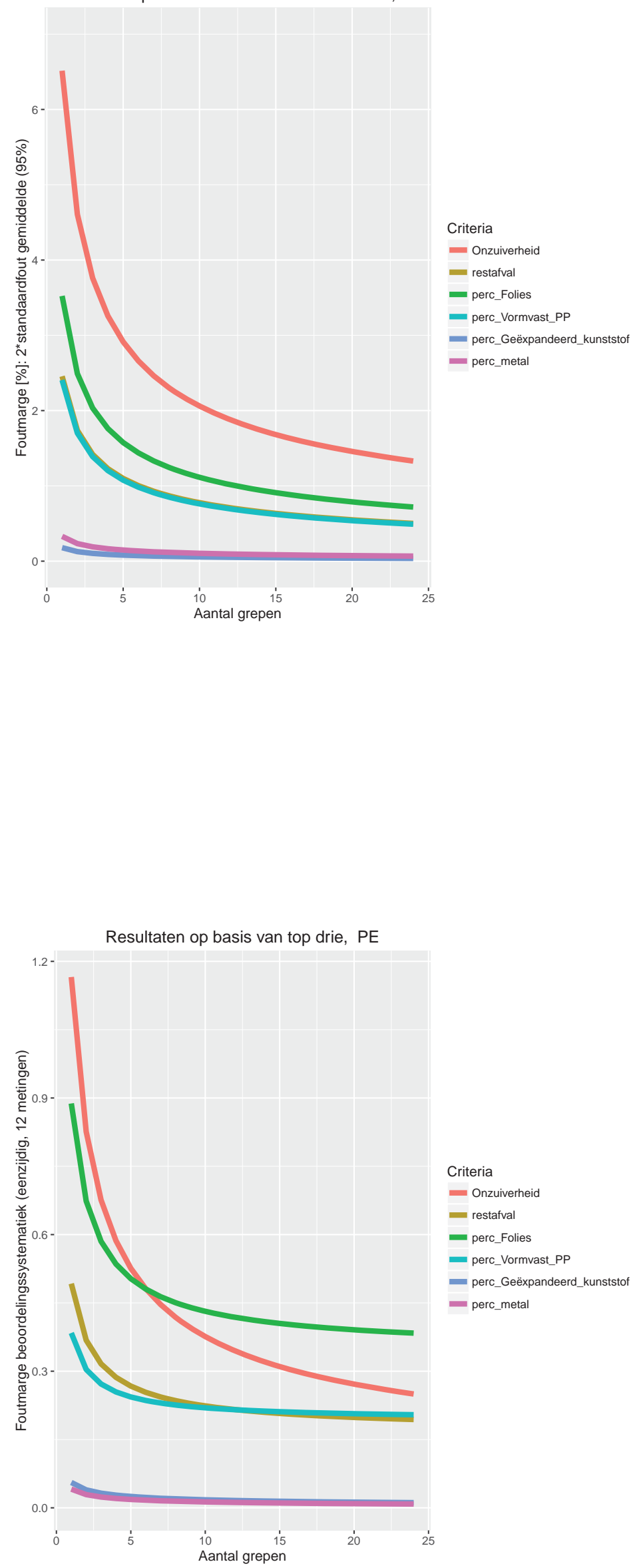

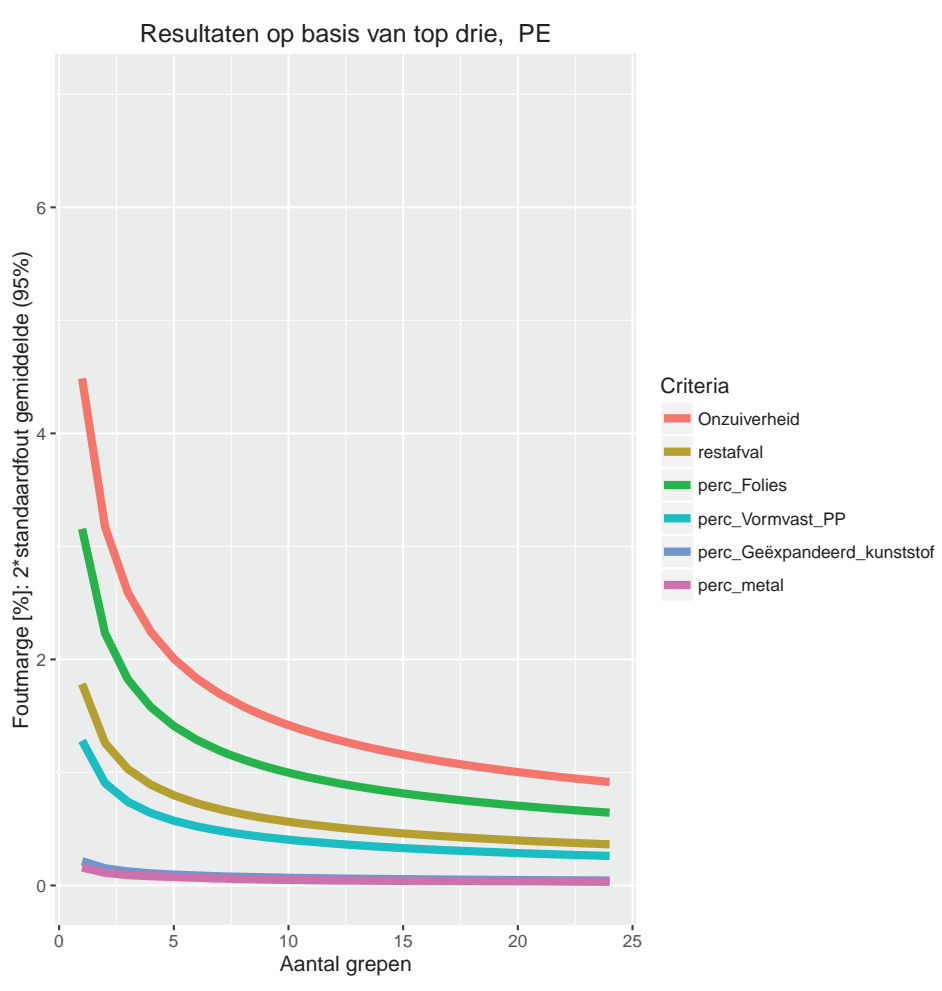


PP
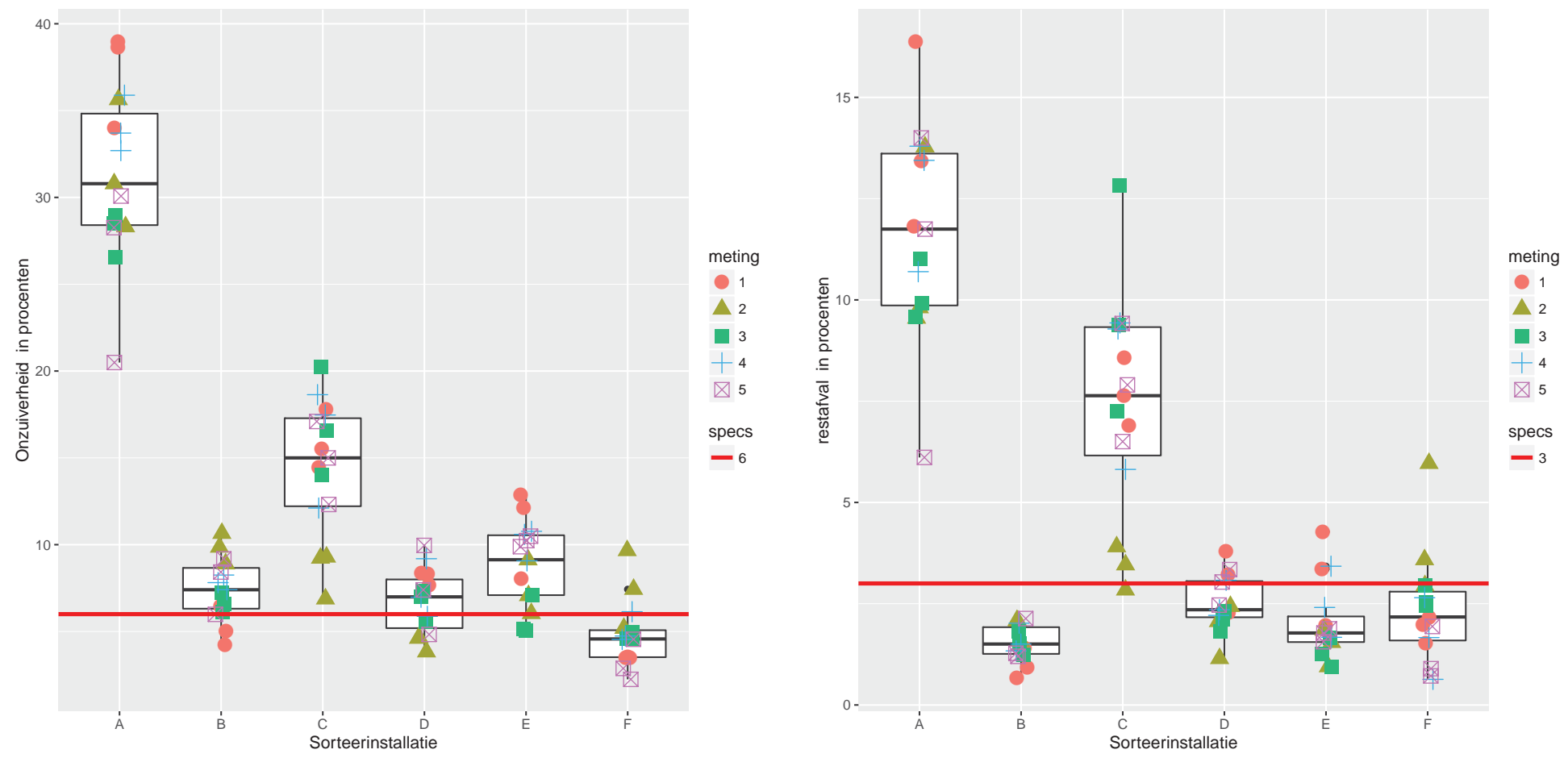

PP

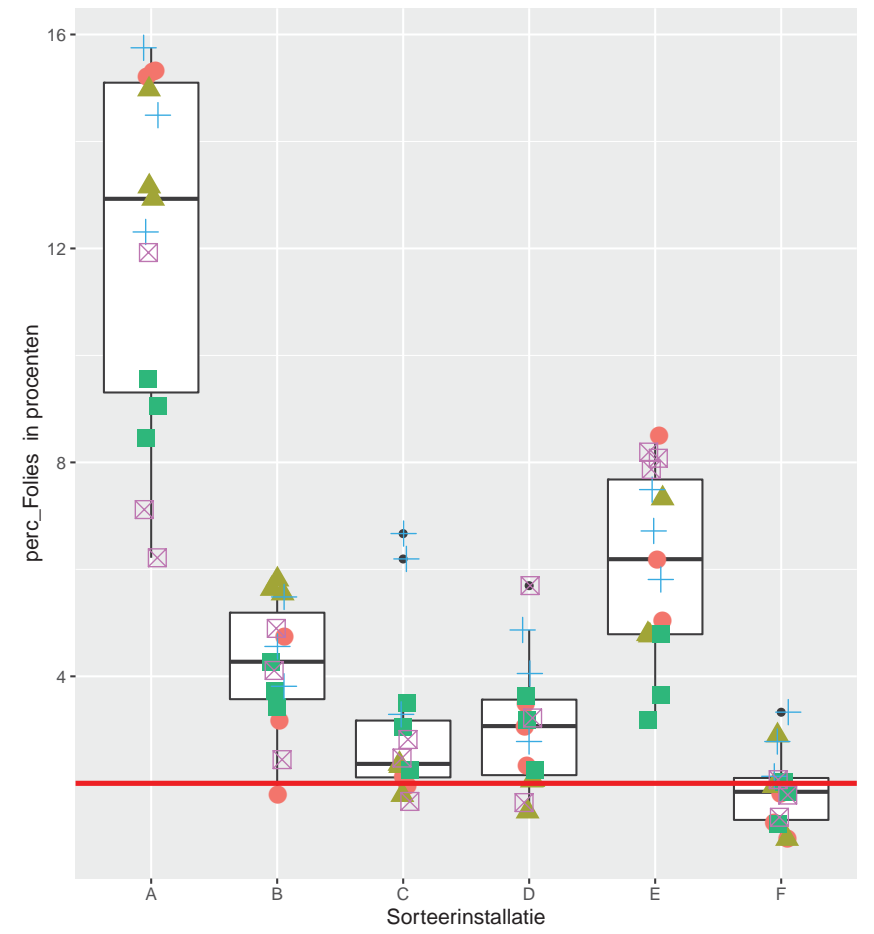

PP

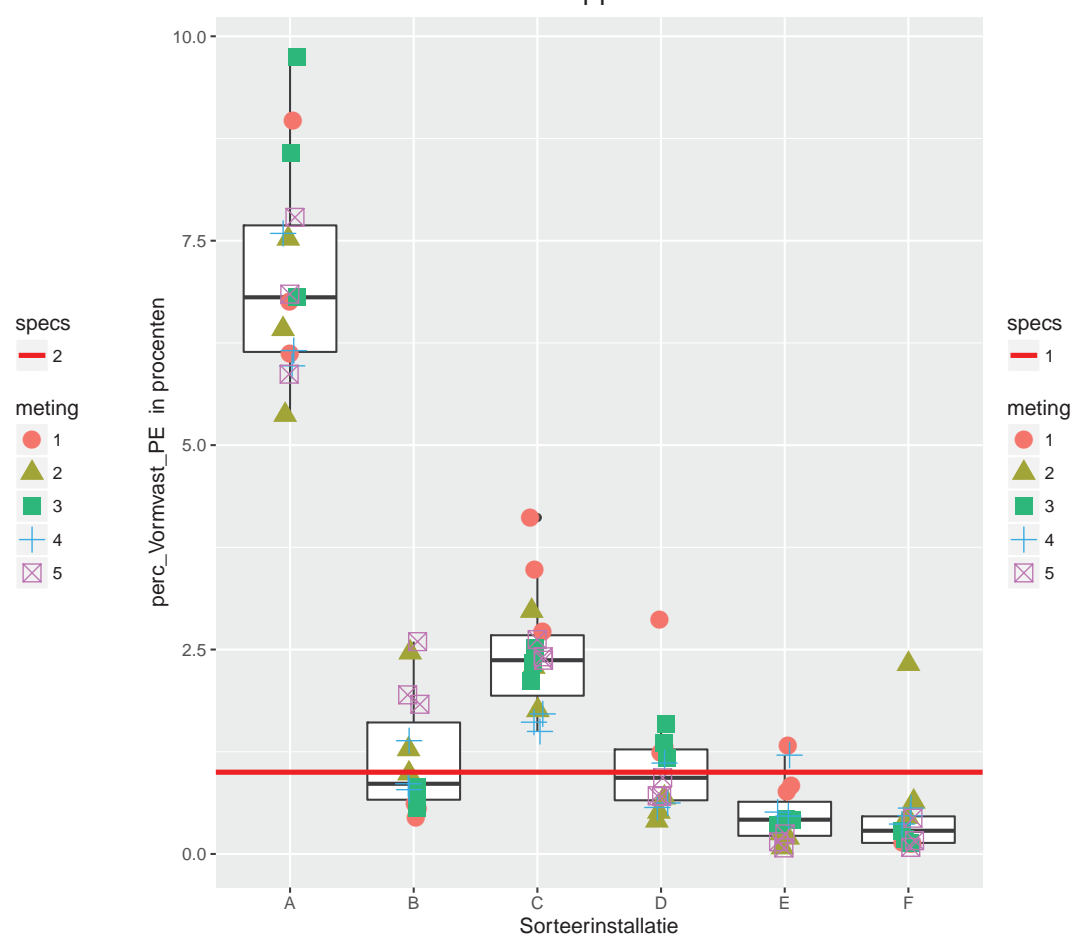


PP

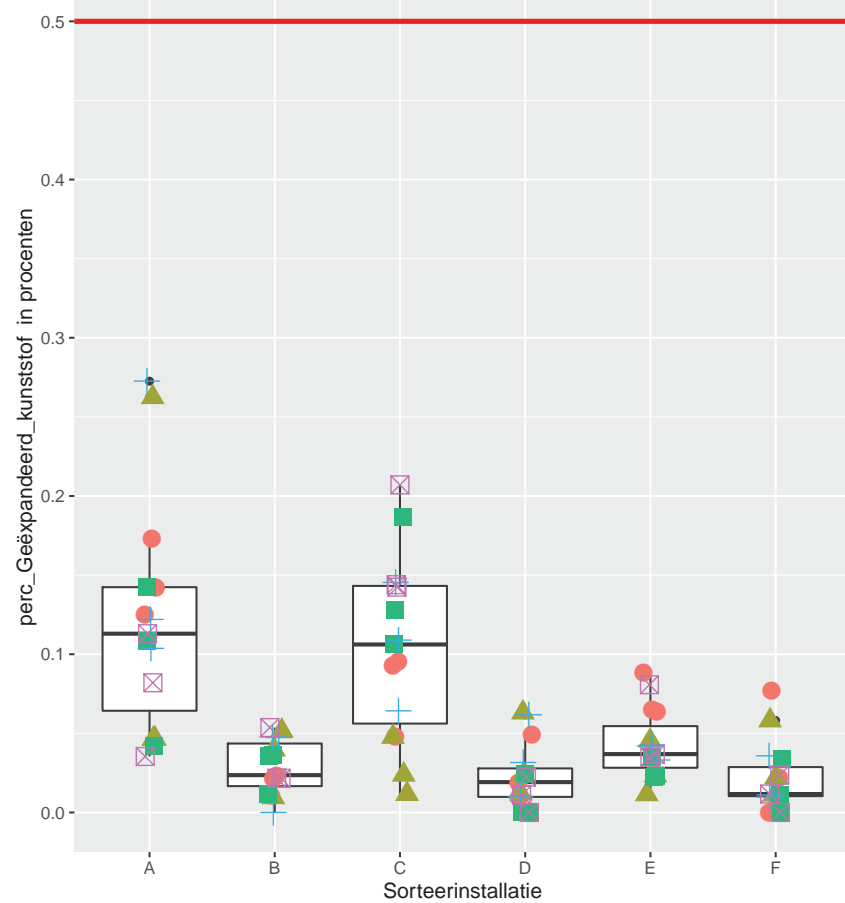

PP

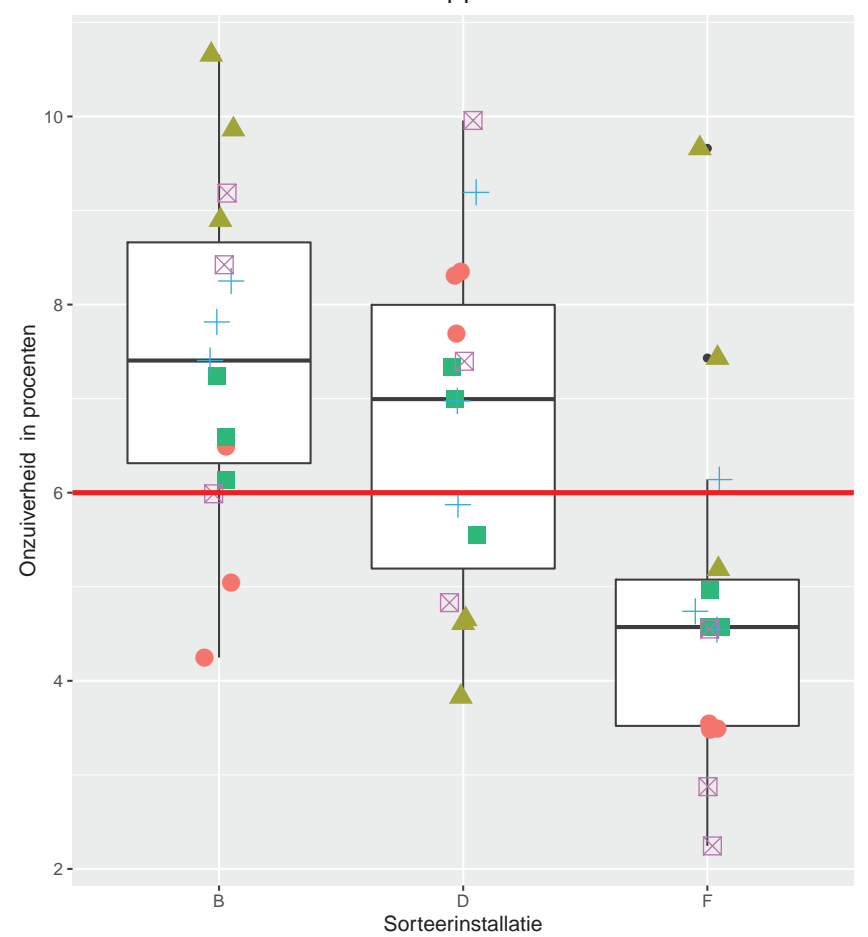

PP

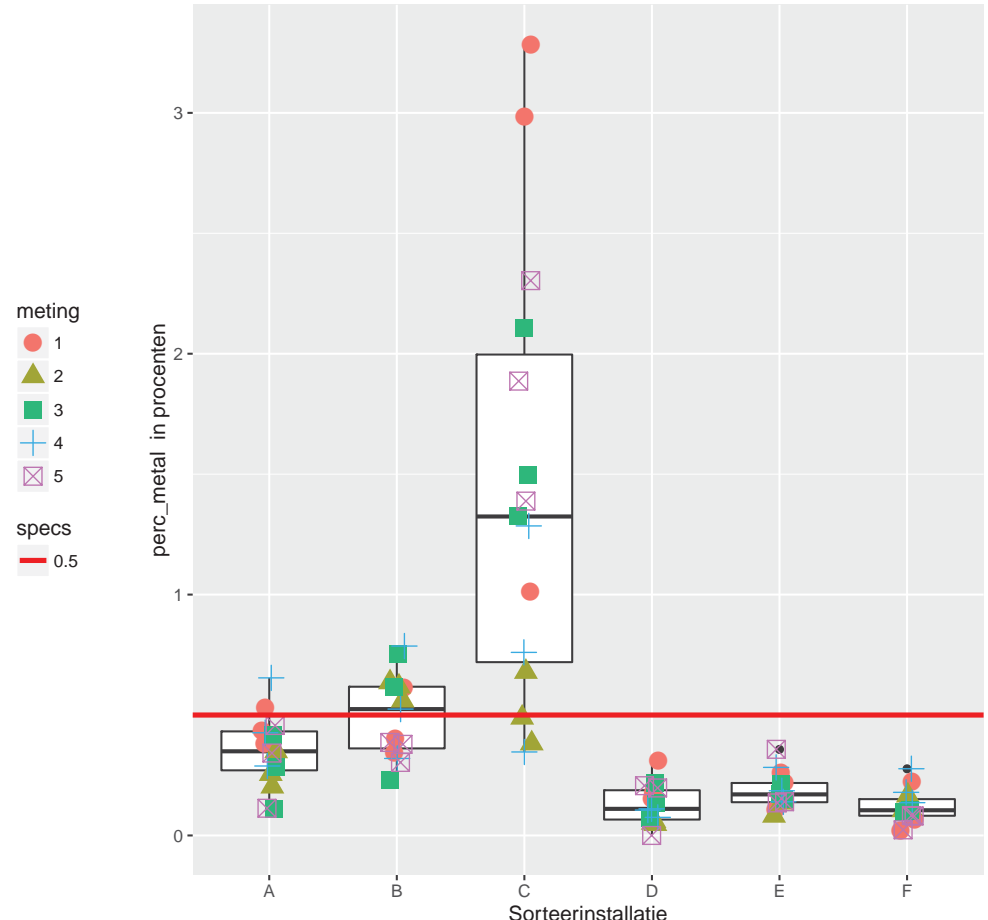

meting
1
$\triangle 2$
$\square$
3
+4
$\square 5$
specs
-0.5

PP

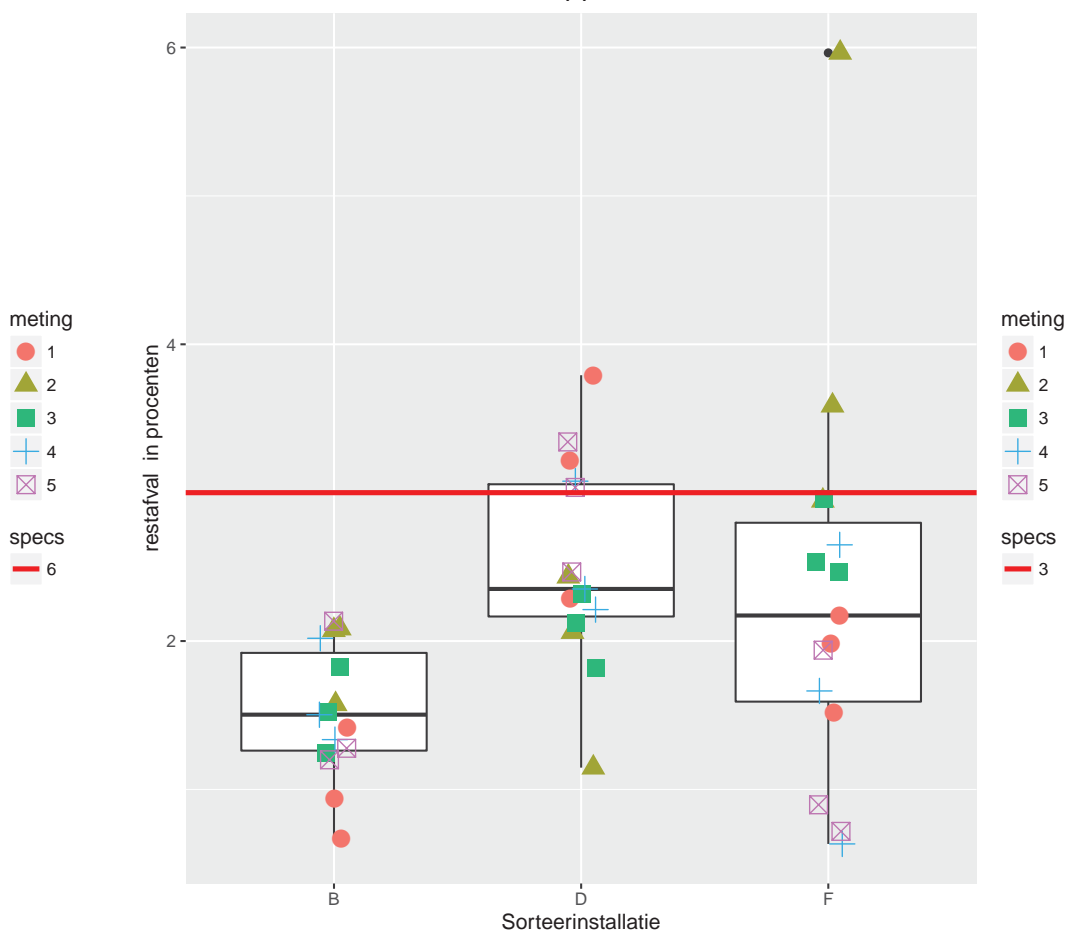



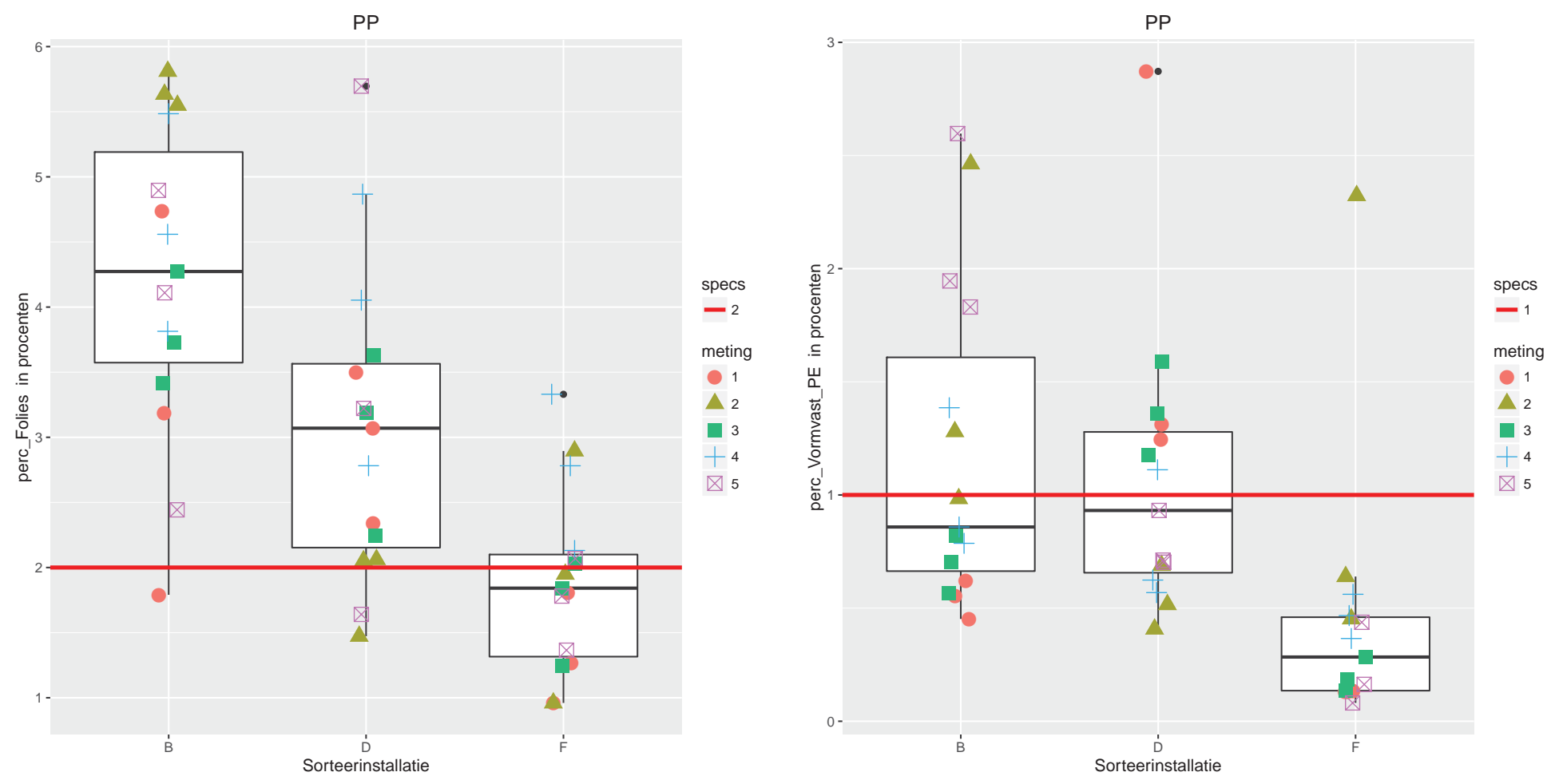

PP

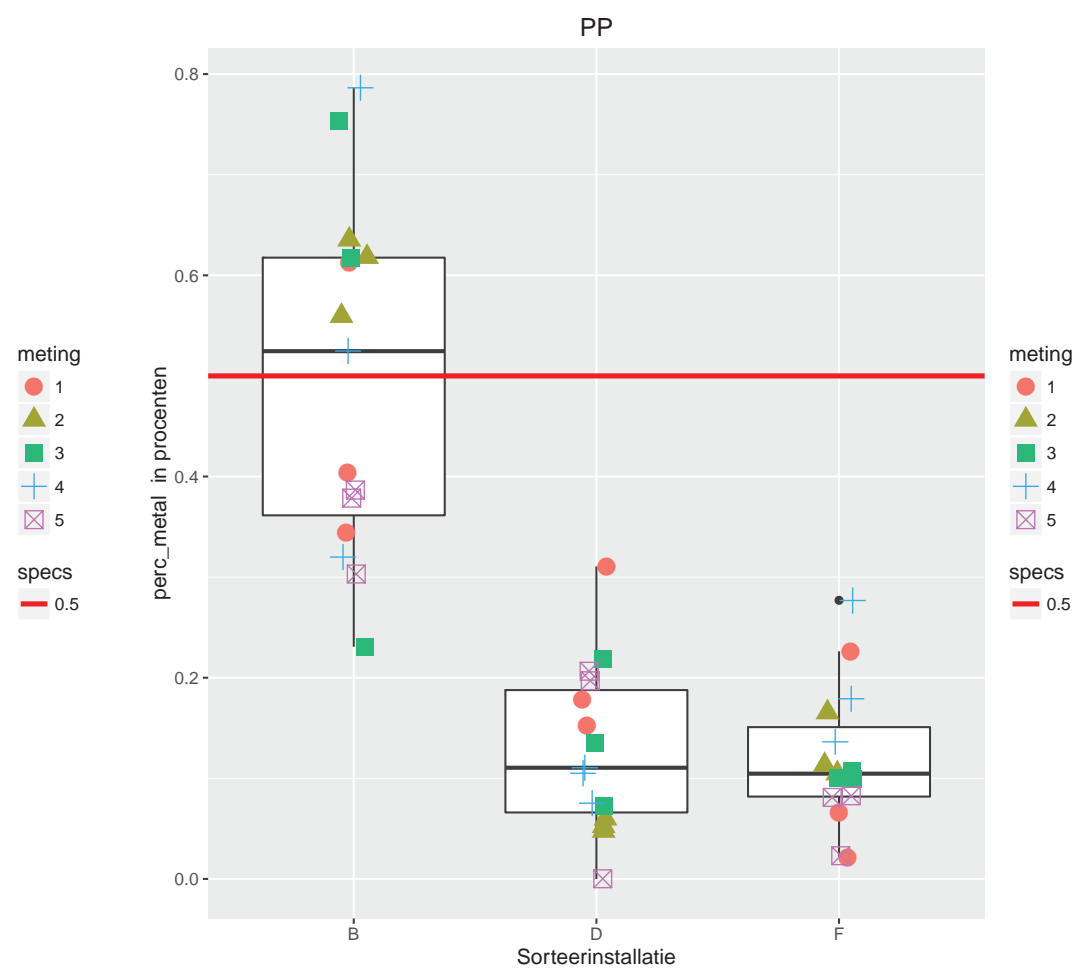


Resultaten op basis van alle sorteerinstallaties, PP

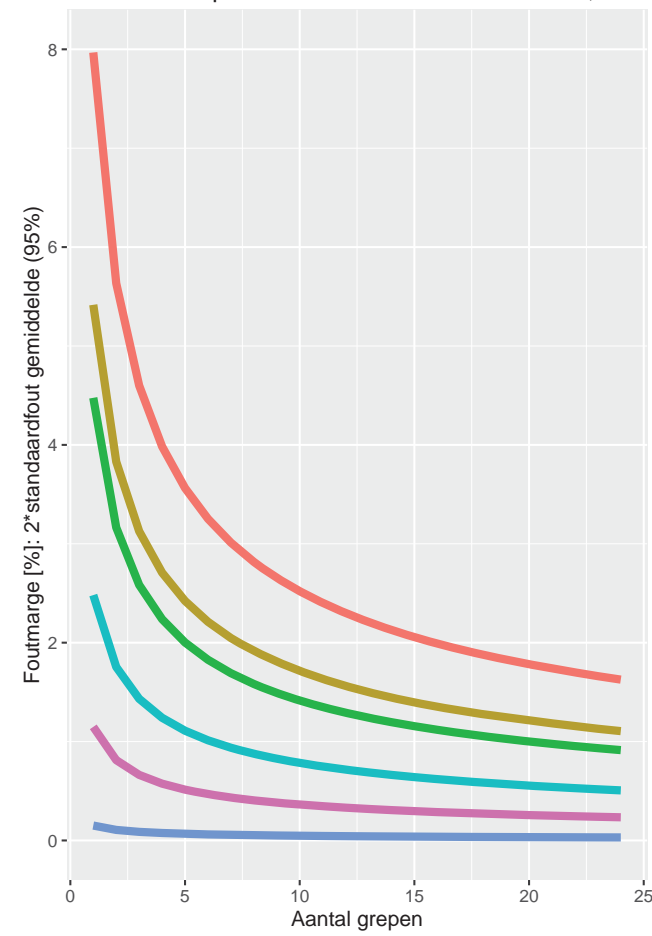

Criteria

Onzuiverheid

- restafval

- perc_Folies

- perc_Vormvast_PE

- perc_Geëxpandeerd_kunststo

- perc_metal

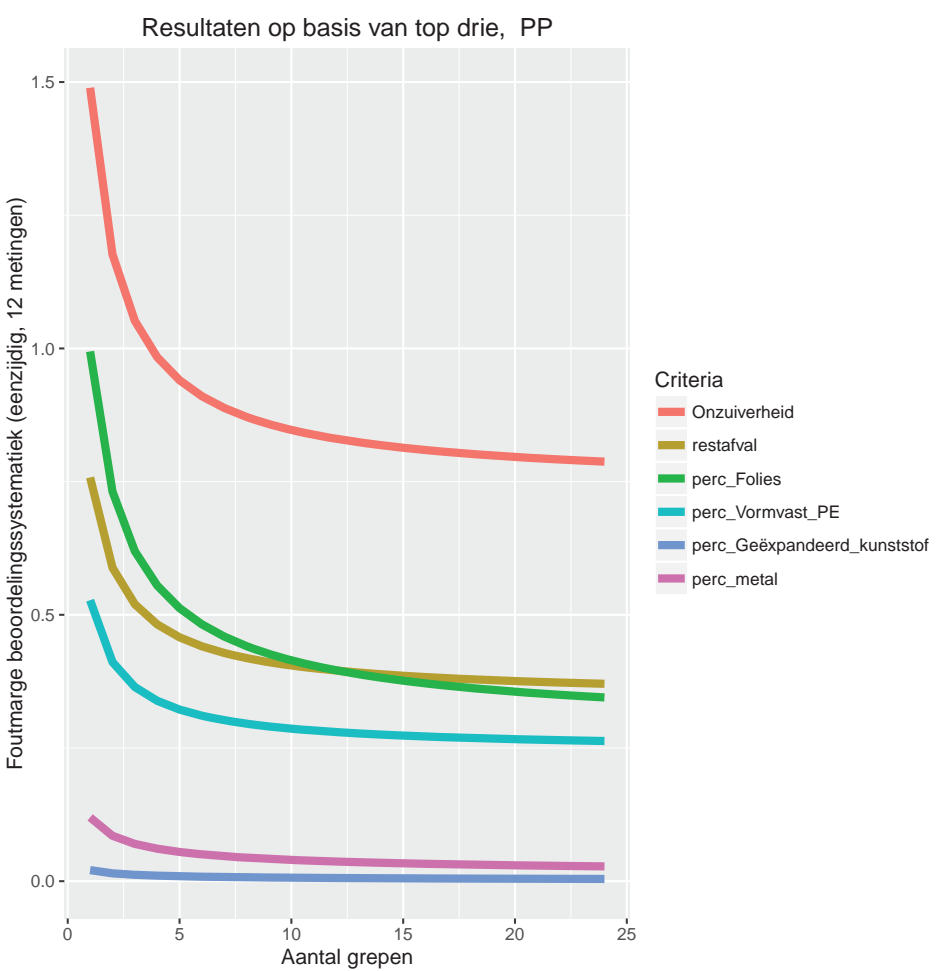

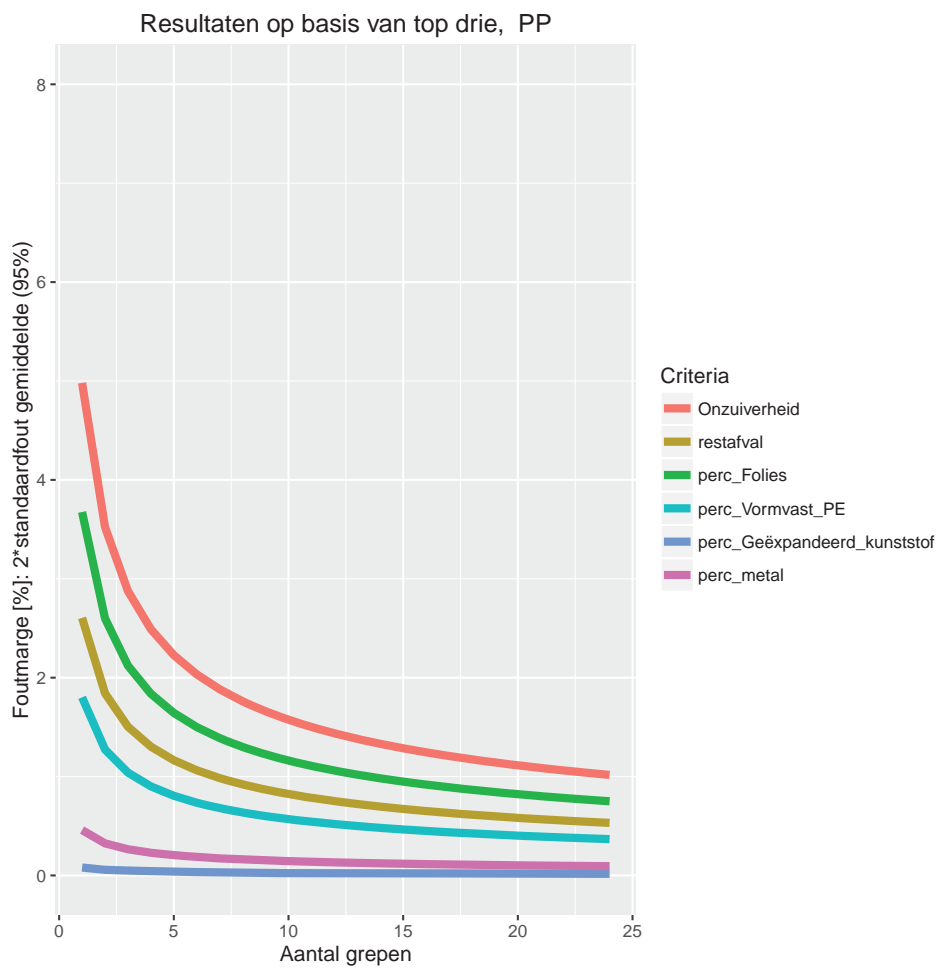



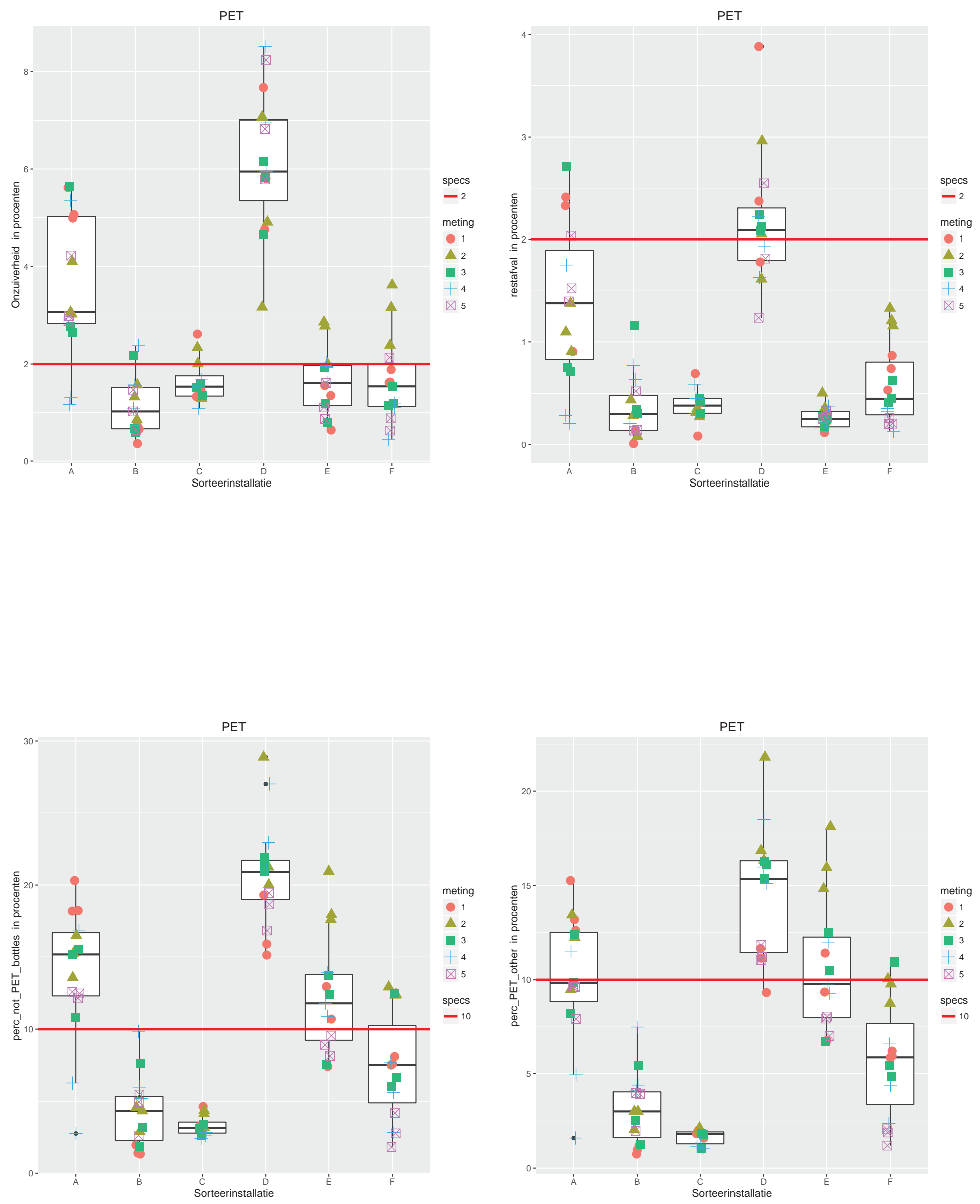
PET

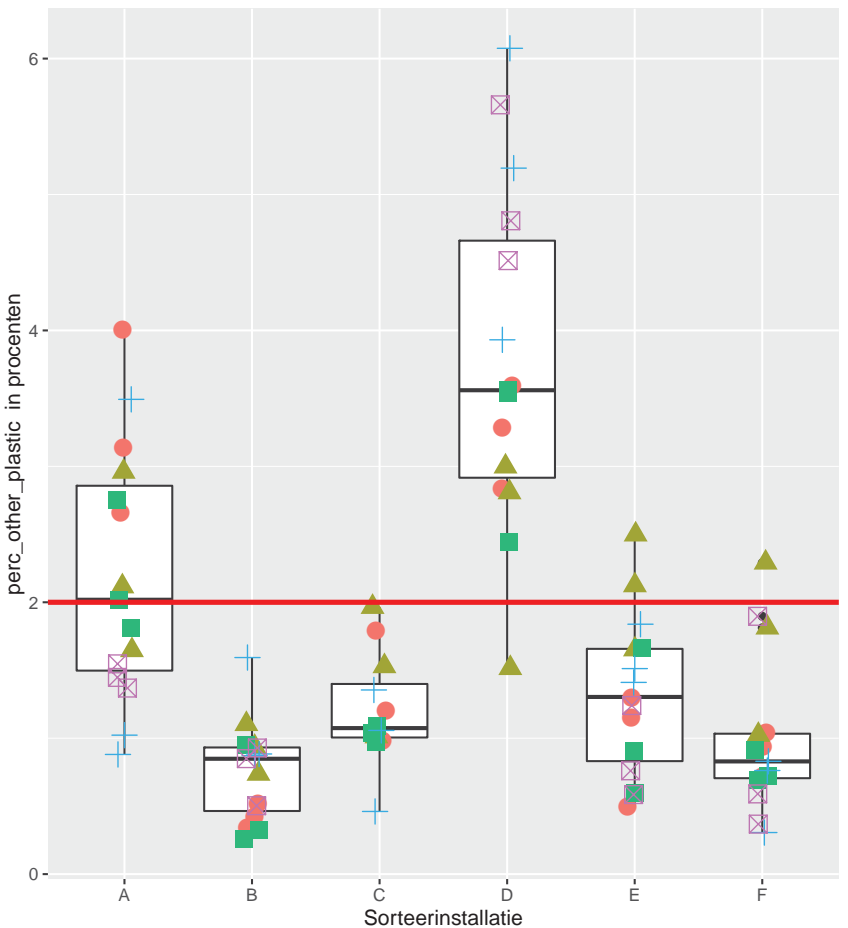

PET

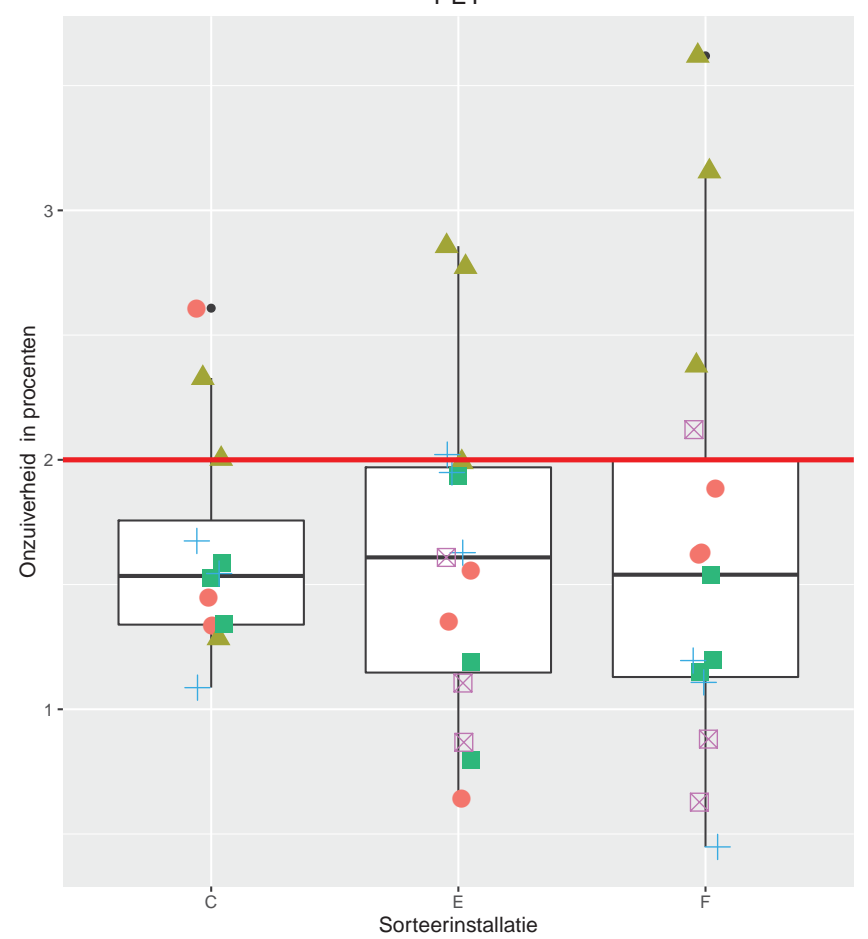

PET

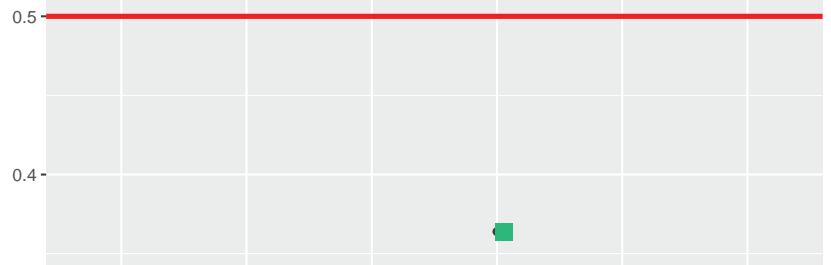

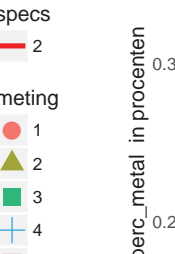

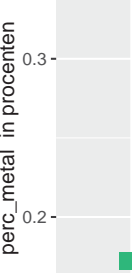

meting

$\triangle 2$

3

$-4$

$\bigotimes 5$

specs

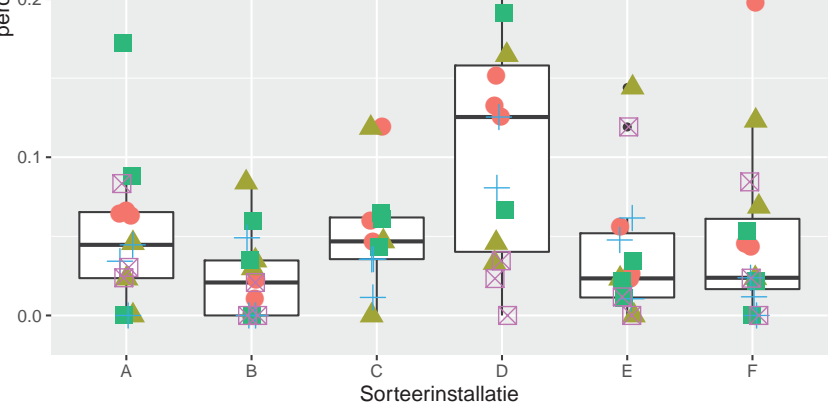

$-0.5$

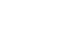

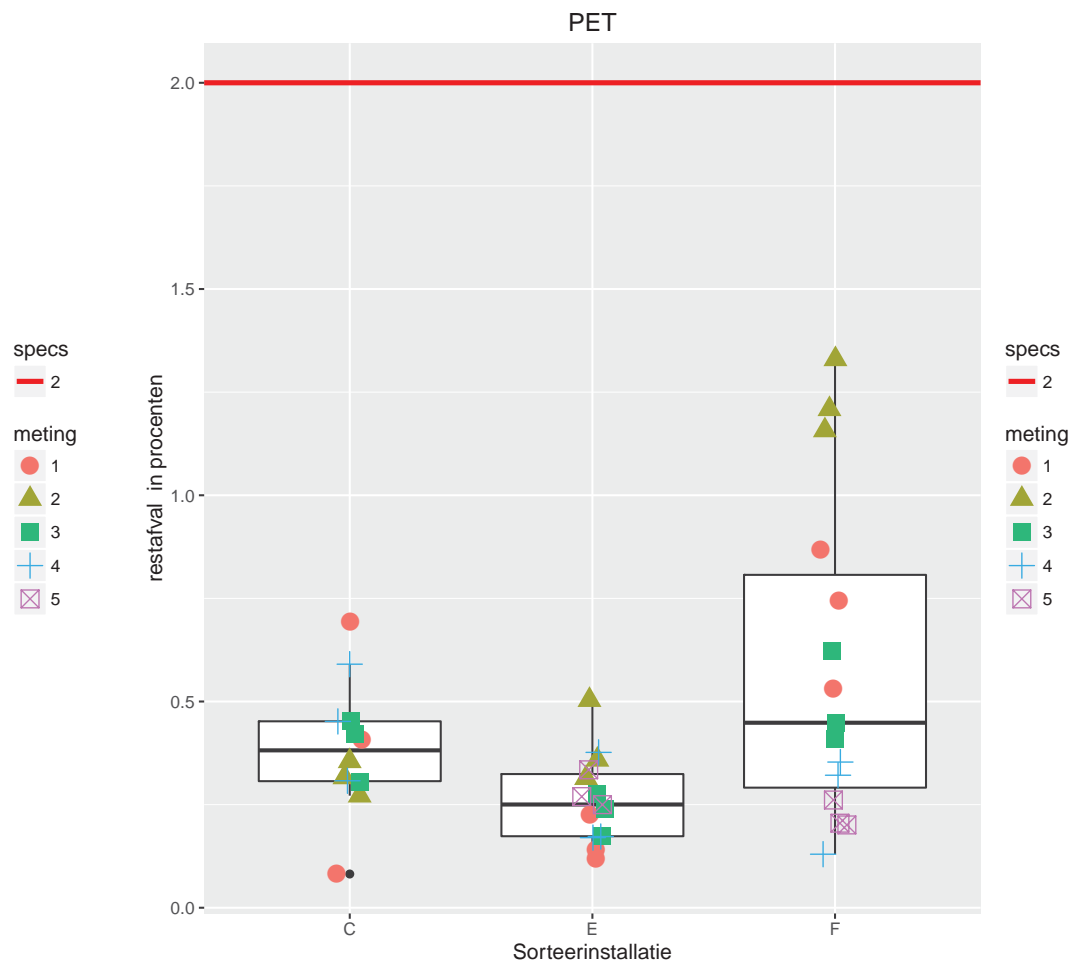



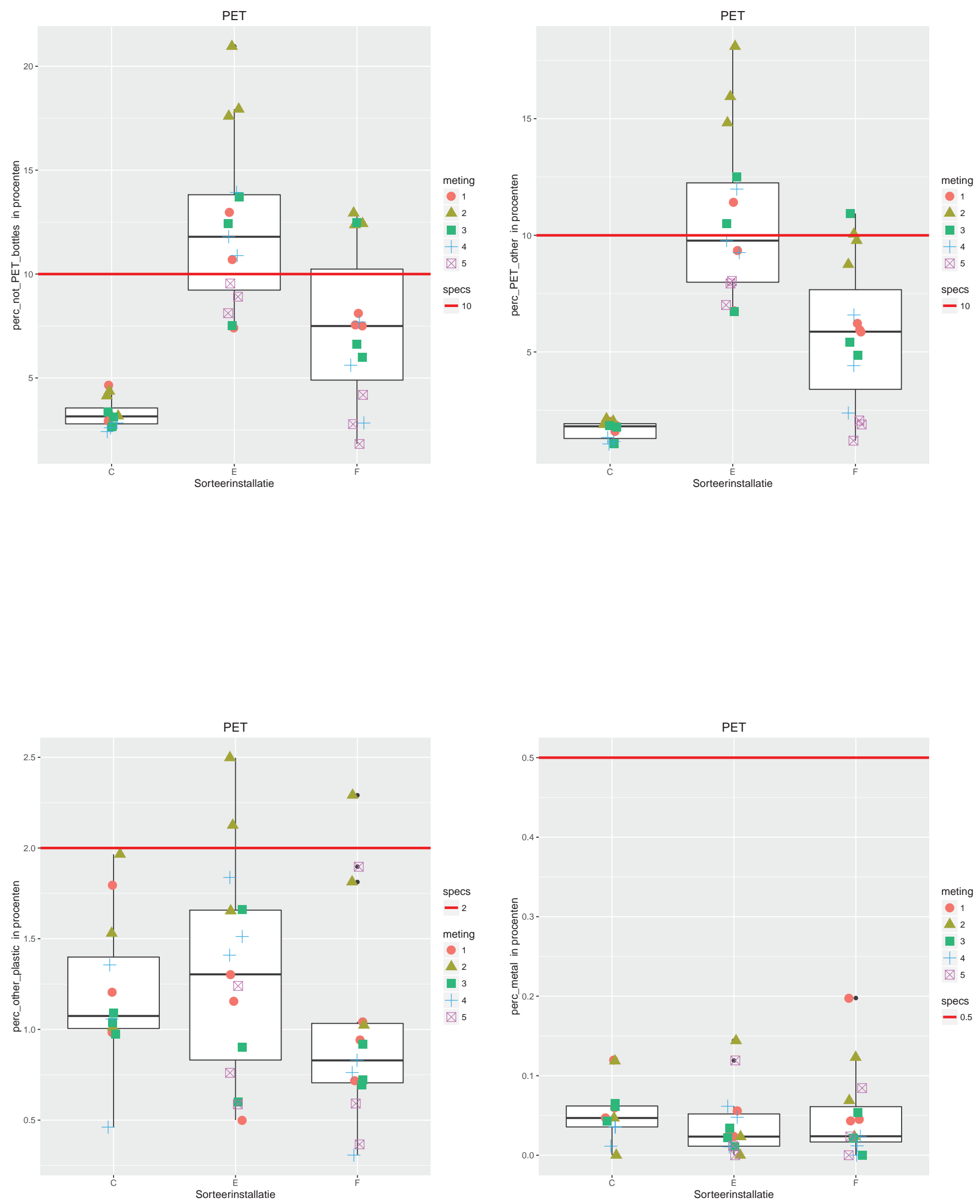
Resultaten op basis van alle sorteerinstallaties, PET

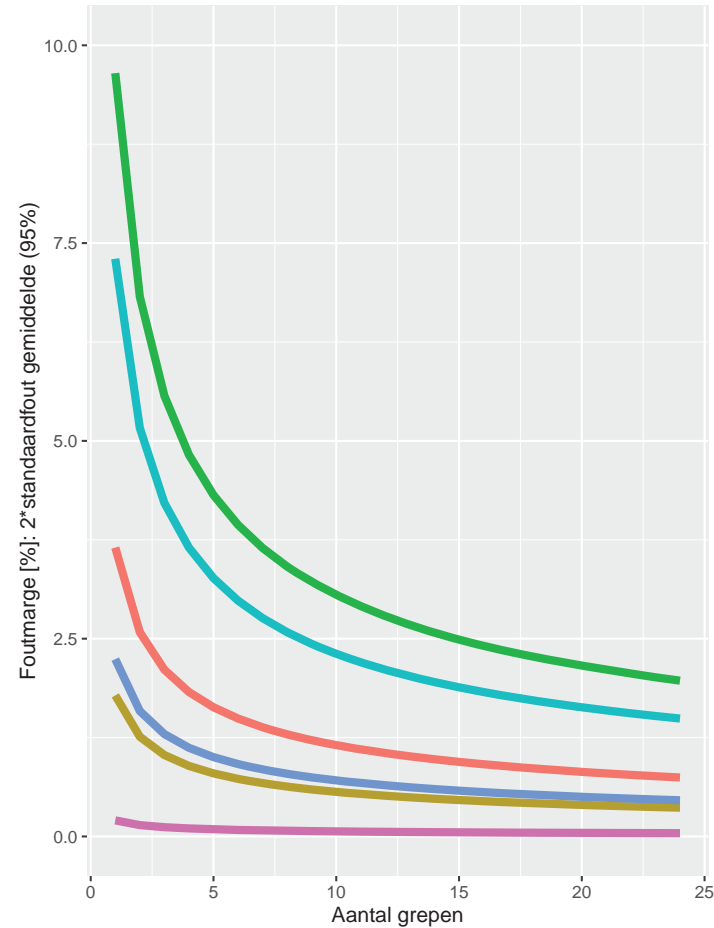

Criteria

Onzuiverheid

- restafval

perc_not_PET_bottles

- perc_PET_other

- perc_other_plastic

- perc_metal

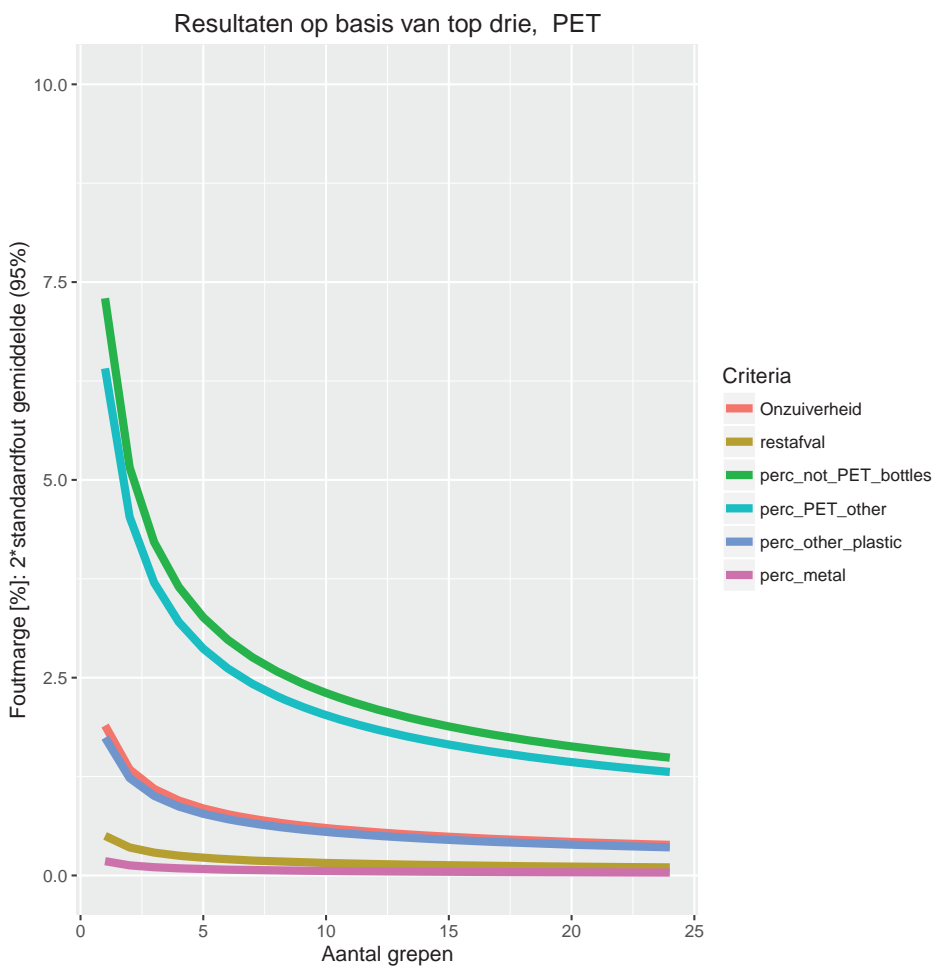

Resultaten op basis van top drie, PET

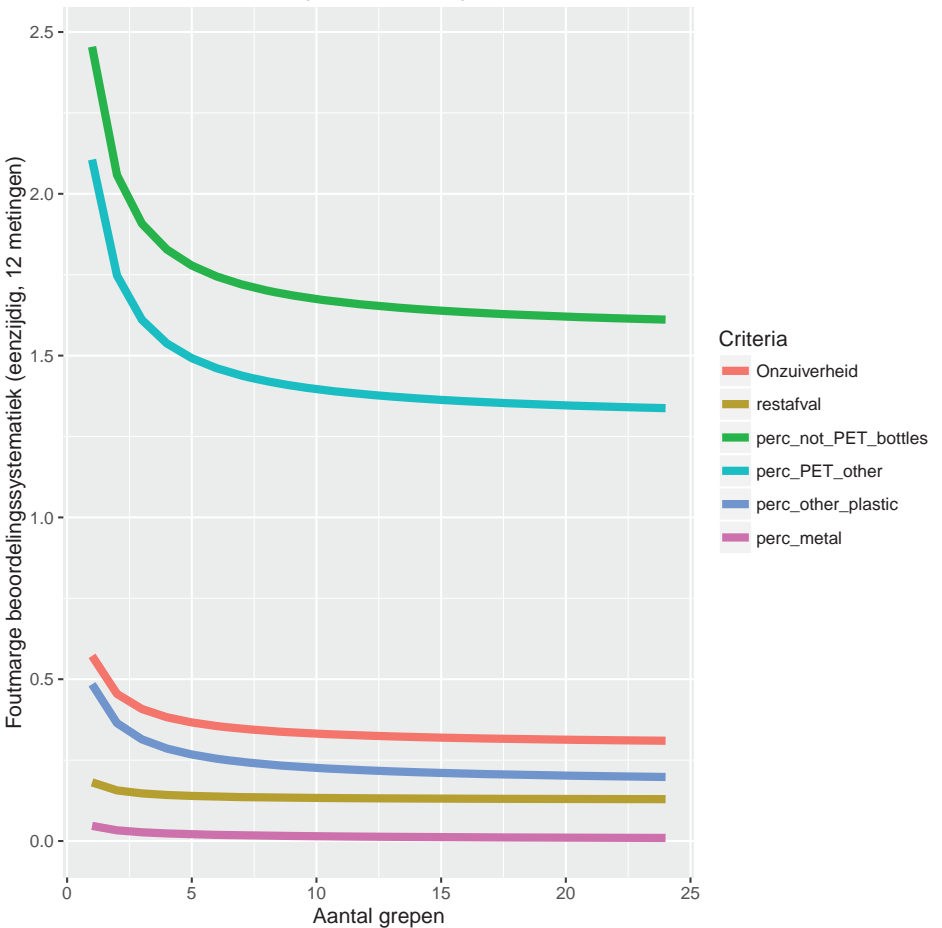




\title{
$2^{\text {nd }}$ opinion on the report \\ "Statistische onderbouwing aantal grepen voor het schatten van de onzuiverheid in gesorteerde kunststofproducten"
}

\author{
Report (final-version)
}

Commissioned by:

Nederland van Afval naar Grondstof (nedvang)

Schorpioenstraat 290/4e etage

3067 KW Rotterdam

the Netherlands

Vereniging Nederlandse Gemeenten (VNG)

Published June 2017:

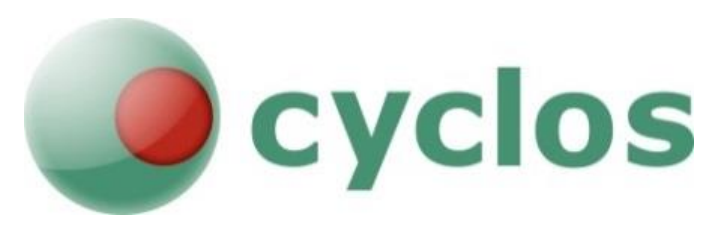

\author{
cyclos GmbH - www.cyclos.de \\ Westerbreite 7 \\ 49084 Osnabrück \\ Germany
}

Dr.-Ing. Stephan Löhle

Mareen Müller
Publicly certified expert on packaging disposal, WEEE disposal - Appointed by the Chamber of Commerce and Industry; Competent: Chamber of Commerce and Industry Osnabrück - Emsland - Grafschaft Bentheim Publicly certified expert on packaging disposal - Appointed by the Chamber of Commerce and Industry; Competent: Chamber of Commerce and Industry Osnabrück - Emsland - Grafschaft Bentheim 
$2^{\text {nd }}$ opinion on the report "Statistische onderbouwing aantal grepen voor het schatten van de onzuiverheid in gesorteerde kunststofproducten"

\section{Context and subject of the review}

cyclos was commissioned in October 2016 to give review (2nd opinion) to the research written by the Wageningen University. The following comments and annotations relate to the present report "Statistische onderbouwing aantal grepen voor het schatten van de onzuiverheid in gesorteerde kunststofproducten" of Eric Boer und Ulphard van Thoden van Velzen (Wageningen University), draft version, April 2017.

Aim of the research is to determine the statistical uncertainness of quality analyses' results subject to the number of samples (grepen) taken from sorted products (plastic packaging and liquid packaging board):

"In opdracht van de Vereniging Nederlandse Gemeenten (VNG) en Nedvang is onderzocht hoe de onzekerheid in de uitkomsten van kwaliteitscontroles van gesorteerde producten (kunststofverpakkingen en drankenkartons) afhangt van het aantal grepen dat genomen wordt."

By using the statistical uncertainness a measuring error (foutmarge) is calculated that should be taken into account in the rebate calculation (beoordelingssystematiek). Regarding to WUR interpreting the result or giving recommends is not scope of the research:

"De interpretatie hiervan was geen onderdeel van de opdracht, dus er zullen ook geen conclusies worden getrokken over het benodigd aantal grepen."

\section{$22^{\text {nd }}$ opinion on the report}

Data basement for calculating the uncertainness are monthly, actual measured data of the last five months in 2016 at up to seven different sorting plants. Each time 12 samples were used to perform the quality analyses.

For the statistical analysis the following assumptions (see point 2.1 and 2.2 WUR-report) apply: To calculate the standard deviation between partial measurements (deelmeetingen $=$ submonster) $\mathrm{a}$ normal distribution (see also below) is assumed which further is used to determine a measurement error (foutmarge) per sorted product and per each (sub-)criterium laid down in the related DKRspecifications. The confidence interval (betrouwbaarheid) is $95 \%$. The acceptable measuring error (foutmarge) depends on the number of samples taken into this calculation. This is determined for a range of one to 24 samples (grepen) per quality analysis in the present report.

Comment:

It is reasonable to use a normal distribution and a confidence interval of $95 \%$ to determine measurement errors or compositions of mixed waste streams. These approaches are also used in comparable and common measurement standards in Germany like "Richtlinie zur einheitlichen Abfallanalytik in Sachsen" (Sächsisches Landesamt für Umwelt, Landwirtschaft und Geologie (LfULG), 2016) or LAGA PN 98 "Richtlinie für das Vorgehen bei physikalischen, chemischen und biologischen Untersuchungen im Zusammenhang mit der Verwertung/Beseitigung von Abfällen" (Mitteilung der Länderarbeitsgemeinschaft Abfall (LAGA) 32, 2001). Whether a normal distribution of data is existent and suitable for the further calculation is not verified finally in this report.

In point 2.3 WUR-report the following assumptions apply: 
$2^{\text {nd }}$ opinion on the report "Statistische onderbouwing aantal grepen voor het schatten van de onzuiverheid in gesorteerde kunststofproducten"

- the samples (grepen) are assumed to be representative with regard to its composition (same as stock)

- data have a normal distribution, that means also the calculated measurement errors are symmetric

- variations between the single samples (grepen) are assumed to be equal for all sorting plants.

\section{Comment:}

These assumptions allow to determine the variation between samples and to calculate a tolerable measurement error depending on the numbers of samples. These assumptions have to be seen as a required "simplification" in order to build a practical statistical system and to achieve valid results about the quantity of measurement errors.

In point 3.1 the results for the sorting product Mixed Plastics (DKR 350) are visualised as an example. The figure (figuur 1) clarifies the spreading respectively the concentration of single measuring data (here: sum of impurities) for each partial measurement (deelmeetingen $=$ submonster $=4$ grepen).

\section{Comment:}

Based on the data used for this research the calculation and the shown results are plausible. Not discussed or furthermore adjusted are the following aspects that might have impact on the variation of the results (basic data):

- changed operation mode, processing of the sorting plant, structural changes (if applicable)

- (in-)consistency in sorting analysis procedure (different teams, output of different types of Mixed Plastics)

- (in-)consistency in allocation of partial measurement (deelmeetingen = submonster $=4$ grepen $)$

In the following the three "top runner" are evaluated, based on the above mentioned methodology. "Top runners" are sorting plants with the lowest variation in their results - regardless of being within a DKR norm limit or not. The evaluation of the three "top runners" is done for each sorting product and each (sub-)criterium mentioned in corresponding DKR specification separately.

\section{Comment:}

The exclusive usage of data of the three "top runners" finally leads to a lower (the lowest) acceptable measurement error than if all measurement results would have been considered. This definition is reasonable in terms of a homogeneous processing of sorting products.

The usage of an acceptable measurement error in the rebate calculation (beoordelingssystematiek) is a targeted compromise where

a) on the one hand an acceptable measurement error (that is not caused by the sorting plant) will not lead to any deduction and

b) on the other hand this smaller acceptable measurement error is determined by the sorting plant with most homogeneous sorting products. 
$2^{\text {nd }}$ opinion on the report "Statistische onderbouwing aantal grepen voor het schatten van de onzuiverheid in gesorteerde kunststofproducten"

The figures (figuur 2 [all five sorting plants] and figuur 3 ["top runner"]) in point 3.3 clarifies the dependency between measurement error and numbers of sample. The illustrated curves are exponentially decreasing: with lower numbers of samples the acceptable measurement error is high and then strongly decreasing when higher numbers of samples apply.

\section{Comment:}

Like figure 3 shows, it is evident that for all (sub-)criterias after 12 samples no further relevant reduction of the measurement error appears. Dependent on the sorting products the results vary: As the measurements errors of all (sub-)criterias for PE (DKR 329) are less than $1 / 3$ of the maximum norm limit for some (sub-)criterias in other sorted products the measurement errors are more than $50 \%$ (e.g. residues in Mixed Plastics (DKR 350) or film in PP (DKR 324).

Should be a reduction of the taken number of samples be eligible (like in point 4 "discussie" mentioned), this has to be oriented towards the "weakest" (sub-)criteria of a certain sorted product, because all (sub-)criterias of one sorted product are analysed at once.

Furthermore, attention should be paid to the following aspect:

Following the meetprotokol point 2.1.4 (version v1.0 - 160310) representativity is achieved by using a mixed sample (monster) consisting of at least 12 samples (grepen) - regardless to the present amount of sorted products in stock (that means the amount/numbers of bales produced between two quality-measurements):

"Het aantal grepen bepaalt sterk de representativiteit van een monster. Hoe meer grepen uit verschillende balen hoe representatiever, maar hier geldt wel de wet van de afnemende meeropbrengsten. Voor materialen vergelijkbaar aan gesorteerde kunststoffen en drankenkartons is dit op minimaal 12 grepen gesteld in Europese normen. Bij 12 grepen is een monster dus voldoende representatief."

The research of WUR does not deal with this aspect. Furthermore (like it is mentioned in the subject of the research), the study does not give any conclusions or recommendation about the number of samples that should be taken into account for calculating a measurement error. 


\section{Reactie op de review "2nd Opinion on the report” June 2017}

\section{Comment 1}

Added analysis of normality and its effects on the results of this report.

\section{Comment 2}

Agreed.

\section{Comment 3}

We have done an analysis on the data as provided by Nedvang. We had no influence and information on the characteristics of the data as mentioned in this comment.

\section{Comment 4}

This is mainly a remark about the "beoordelingssystematiek", which is not the scope of this report.

\section{Comment 5}

We have added a conclusion about the number of samples (grepen). 